$$
\begin{aligned}
& \angle A-S U B-99-66 \\
& \text { RECEIVED } \\
& \text { JUL } 3,2000 \\
& \mathrm{OST}_{\mathrm{T}} \\
& \text { Infe } 13 \text { NaV } 161999
\end{aligned}
$$

\title{
Zircon:
}

\section{A host phase for the disposal of weapons plutonium}

\section{Final report}

1998

\author{
Werner Lutze \\ Rodney C. Ewing \\ K. B. Helean \\ W. L. Gong
}

The University of New Mexico Albuquerque, NM 87131

The University of Michigan Ann Arbor, Michigan 48103

\section{January 1999}

This work was financially supported by Los Alamos National Laboratory under contract $0409 \mathrm{~J} 00043 \mathrm{P}$, Task Order No, 028 


\section{DISCLAIMER}

This report was prepared as an account of work sponsored by an agency of the United States Government. Neither the United States Government nor any agency thereof, nor any of their employees, make any warranty, express or implied, or assumes any legal liability or responsibility for the accuracy, completeness, or usefulness of any information, apparatus, product, or process disclosed, or represents that its use would not infringe privately owned rights. Reference herein to any specific commercial product, process, or service by trade name, trademark, manufacturer, or otherwise does not necessarily constitute or imply its endorsement, recommendation, or favoring by the United States Government or any agency thereof. The views and opinions of authors expressed herein do not necessarily state or reflect those of the United States Government or any agency thereof. 


\section{DISCLAIMER}

Portions of this document may be illegible in electronic image products. Images are produced from the best available original document. 


\title{
Zircon: \\ A host phase for the disposal of weapons plutonium
}

Final report

1998

\author{
Werner Lutze \\ Rodney C. Ewing ${ }^{1}$ \\ K. B. Helean \\ W. L. Gong
}

The University of New Mexico

Albuquerque, NM 87131

${ }^{1}$ The University of Michigan

Ann Arbor, Michigan 48103

January 1999

This work was financially supported by Los Alamos National Laboratory under contract 0409J0004-3P, Task Order No. 028 


\section{Table of contents}

Executive summary......................................................... 1

1. Introduction........................................................ 3

2. Ceramic waste form candidates.......................................... 4

Pyrochlore and zirconolite

Apatite

Monazite

Zirconia

Zircon

3. Zircon's chemical durability - previous work (literature)......................... 8

3.1 Zircon dissolution kinetics and solubility studies

3.2 Thermodynamics of zircon dissolution

3.2.1 Thermal stability and thermodynamics of zircon

3.2.2 Solubility of zircon - a closer look at Tole's study

3.2.3 The $\mathrm{U}-\mathrm{Zr}$ analogy

3.3 Conclusions

4. Measurement of the dissolution rate of crystalline zircon.

4.1 Sample description

4.1.1 Analytical techniques

4.1.2 Results

4.2 Dissolution experiments

4.3 Results

4.3.1 Dissolution rate of zircon at $250^{\circ} \mathrm{C}$

4.3.2 Dissolution rate of zircon at $200^{\circ} \mathrm{C}$

4.3.3 Dissolution rate of zircon at $120^{\circ} \mathrm{C}$

4.3.4 Activation energy of zircon dissolution

4.3.5 Summary of results

4.4 Discussion

5. Modification of the Soxhlet extractor.......................................... 34

6. Measurement of the dissolution rate of amorphous, hydrous zircon.............. 35

6.1 Sample description

6.2 Analytical techniques

6.3 Results

6.4 The static dissolution test of hydrous zircon

6.5 Conclusion 
7. Synthesis of zircon solid solutions with actinides................................... 43

7.1 Experimental

7.2 Microstructure and phase constituents of sintered products

7.3 Solubility of actinides in zircon

References............................................................... 55 


\section{Executive summary}

Research was conducted into the possible use of zircon $\left(\mathrm{ZrSiO}_{4}\right)$ as a host phase for storage or disposal of excess weapons plutonium. Zircon is one of the most chemically durable minerals. Its structure can accommodate a variety of elements, including plutonium and uranium. Natural zircon contains uranium and thorium together in different quantities, usually in the range of less than one weight percent up to several weight percent. Zircon occurs in nature as a crystalline or a partially to fully metamict mineral, depending on age and actinide element concentration, i.e., on radiation damage. These zircon samples have been studied extensively and the results are documented in the literature in terms of radiation damage to the crystal structure and related property changes, e.g., density, hardness, loss of uranium and lead, etc. Thus, a unique suite of natural analogues are available to describe the effect of decay of ${ }^{239} \mathrm{Pu}$ on zircon's structure and how zircon's physical and chemical properties will be affected over very long periods of time. Actually, the oldest zircon samples known are over 3 billion years old. This period covers the time for decay of ${ }^{239} \mathrm{Pu}$ (half-life $24,300 \mathrm{yr}$.) and most of its daughter ${ }^{235} \mathrm{U}$ (half-life 700 million yr.). Because of its chemical durability, even under extreme geological conditions, zircon is the most widely used mineral for geochronological dating (7000 publications). It is the oldest dated mineral on earth and in the universe.

Zircon has already been doped with about 10 weight percent of plutonium. Pure $\mathrm{PuSiO}_{4}$ has also been synthesized and has the same crystal structure as zircon. However, use of zircon as a storage medium or waste form for plutonium requires further materials characterization. Experiments can either be conducted in laboratories where plutonium can be handled or plutonium can be simulated by other elements, and experiments can be done under less restricted conditions.

We conducted work with zircon doped with thorium, uranium and cerium, respectively. We synthesized various zircon compositions and studied the solid solution properties of mixed $(\mathrm{Zr}, \mathrm{X}) \mathrm{SiO}_{4}[\mathrm{X}$ represents $\mathrm{Th}, \mathrm{U}, \mathrm{Ce}$, respectively]. We measured the dissolution rate of pure crystalline zircon at elevated temperatures and of an amorphous hydrated zircon.

This final report together with two previous annual reports summarize the accomplishments made in two areas: 1) synthesis of zircon solid solutions with $T h, U$, and Ce; and 2) measurement of the chemical durability of zircon. The focus of the final report is on the measurement of zircon's dissolution rate in water and on the determination of solubility limits of $\mathrm{Th}, \mathrm{U}$, and $\mathrm{Ce}$ in zircon. The following results were obtained: 
1. It was established that existing data on zircon dissolution cannot be used to determine the mineral's forward dissolution rate. Existing data do indicate that there is an effect of radiation damage on zircon dissolution and that the rate may be a factor of 100 increased for the metamict material compared with crystalline zircon.

2. The forward dissolution rate of synthetic crystalline zircon was determined to be

$$
\begin{aligned}
& \left(4.1 \times 10^{-4} \pm 0.1\right) \mathrm{gm}^{-2} \mathrm{~d}^{-1} \text { at } 250^{\circ} \mathrm{C},\left(1.7 \times 10^{-4} \pm 0.1\right) \mathrm{gm}^{-2} \mathrm{~d}^{-1} \text { at } 200^{\circ} \mathrm{C} \text {, and } \\
& \left(7.1 \times 10^{-5} \pm 0.04\right) \mathrm{gm}^{-2} \mathrm{~d}^{-1} \text { at } 120^{\circ} \mathrm{C} \text {. The extrapolated value at } 90^{\circ} \mathrm{C} \text { is } \\
& 4.6 \times 10^{-4} \mathrm{gm}^{-2} \mathrm{~d}^{-1} \text {. }
\end{aligned}
$$

The activation energy is $23.2 \mathrm{~kJ} / \mathrm{mole}$, indicating a relatively weak dependence of the dissolution rate on temperature. The experiments were conducted in water with a pressurized Soxhlet extractor.

3. The forward dissolution rate of hydrous, amorphous (gel) zircon was determined to be $8.5 \times 10^{-3} \mathrm{gm}^{-2} \mathrm{~d}^{-1}$ at $90^{\circ} \mathrm{C}$ in water. Hydrous zircon was used to derive an upper limit for the effect of amorphization on chemical durability. Metamict zircon samples were not investigated because there was not enough natural material available to conduct dissolution tests in a Soxhlet apparatus. The dissolution rate for hydrous zircon is two orders of magnitude larger than the rate measured for crystalline zircon. This result is consistent with the measurements by Ewing et al. (1982), who measured the chemical durability of crystalline and natural metamict zircon.

4. Zircon samples synthesized by the sol-gel process and high temperature sintering contained various concentrations of $\mathrm{Th}, \mathrm{U}$, and $\mathrm{Ce}$. The solubility limits for these elements in zircon are: 3.2 - 5.1 mole\% for uranium expressed as $\mathrm{USiO}_{4}^{\prime}, 2$ mole\% for thorium as $\mathrm{ThSiO}_{4}$, and $7.1 \pm 1.0$ mole\% for cerium as $\mathrm{CeSiO}_{4}$. The solubility limit of $\mathrm{PuSiO}_{4}$ in zircon is not known exactly. The highest concentration of $\mathrm{Pu}$ in zircon reported in the literature is 9.2 mole\%. We estimate that the solubility limit of $\mathrm{PuSiO}_{4}$ is higher than, but close to, that of "CeSiO".

The properties of zircon are such that the mineral constitutes a chemically durable medium (storage or waste form) for plutonium whose long-term behavior under a variety of repository conditions can be estimated by investigating natural samples.

Future work would have to focus on the determination of plutonium release on dissolution of zircon and on zircon solid solutions that contain neutron absorbers such as hafnium and gadolinium to control criticality. 


\section{Introduction}

The directive resulting from the 1996 Moscow Summit between President Clinton and President Yelsin calls for surplus plutonium to be converted into forms that are resistant to reuse in nuclear weapons. The question is how to safely dispose of 100 tons of weapons grade plutonium declared surplus at the end of the Cold War. Additionally, there are impure chemical forms of plutonium that are also considered surplus.

It has been suggested to convert pure forms of plutonium ( $\mathrm{Pu}-\mathrm{Ga}$ alloys and $\mathrm{PuO}_{2}$ ) into mixed-oxide (MOX) fuel and to irradiate this fuel in commercial nuclear power reactors. In this way electrical energy would be generated, and the remaining plutonium would be contained in discharged (spent) reactor fuel. In this ceramic form, plutonium is believed to be sufficiently proliferation resistant because it is shielded by strong radiation. The deterrent provided by spent fuel is called the spent fuel standard.' The validity of the spent fuel standard, as a barrier against fast and efficient recovery of plutonium, can be questioned $^{2}$ since shortcuts have been published ${ }^{3}$ and new ones are occasionally discovered. $^{4}$

Chemical forms of plutonium not considered for conversion into MOX require other methods of treatment and conversion into proliferation resistant waste forms, suitable for storage and disposal. In the United States this inventory may be as high as 50 tons of plutonium. The waste form currently under development is a ceramic, though glasses have been studied as well. ${ }^{5}$ If properly selected and manufactured, ceramic and vitreous host phases can accommodate the chemically impure forms of plutonium currently stored in weapons plutonium processing facilities. Generally, ceramic forms are chemically far more durable than vitreous waste forms, particularly at higher temperatures or in flowing water ${ }^{6}$. This is important, because the waste form is expected to confine ${ }^{239} \mathrm{Pu}\left(2.43 \times 10^{5}\right.$ yr. $)$ and its daughter ${ }^{235} \mathrm{U}\left(\mathrm{t}_{1 / 2}=7 \times 10^{8}\right.$ yr. $)$ for a very long time. Additionally, there are chemically durable and radiation resistant minerals, e.g., baddeleyite $\left(\mathrm{ZrO}_{2}\right)$. These minerals form solid solutions with plutonium and are candidate waste forms for interim storage and disposal of pure plutonium, ${ }^{7}$ should the MOX option not be pursued.

Glass and ceramic waste forms can provide proliferation resistance comparable to that of spent fuel. There are various methods to accomplish this as the following examples show: 
1. A can-in-can concept, where the Pu waste form (ceramic or glass) is embedded in vitrified high-level radioactive waste aims at matching the spent fuel standard.

2. If ceramic or glass waste forms are not embedded in vitrified high-level radioactive waste, an equivalent radiation field can be provided by admixture of ${ }^{137} \mathrm{Cs}$. There is plenty of ${ }^{137} \mathrm{Cs}$ in storage in the United States. Between 10 to 300 years after discharge of the fuel from the reactor, ${ }^{137} \mathrm{Cs}$ determines the dose rate of spent fuel and of vitrified highlevel waste.

3. Plutonium could be burnt in non-fertile reactor fuel, where $\mathrm{UO}_{2}$ is replaced by another ceramic such as $\mathrm{ZrO}_{2}$ or $\mathrm{MgAl}_{2} \mathrm{O}_{4}$. Calculations have shown that over $93 \%$ of the fissile plutonium can be burnt. ${ }^{8}$ The spent non-fertile fuel would meet the spent fuel standard.

4. A chemical method to discourage extraction and reuse of plutonium would be to make plutonium thorium solid solutions. Dissolution of such systems is extremely slow?

5. Plutonium could be disposed of in deep boreholes without a radiation shield.'

The spent fuel standard has been used as a criterion to discriminate between disposal forms for plutonium, and in the United States, led to favoring the can-in-can concept. ${ }^{5}$ Here, a pyrochlore/zirconolite ceramic waste form ${ }^{10}$ has been selected (see in the next section). Russian scientists are working on various options. We believe that several candidate ceramics should be developed and characterized experimentally to select the best for $\mathrm{Pu}$ waste disposal.

This is the final report on experimental studies of zircon as a waste form for excess weapons plutonium. Work reported here complements previous studies summarized in the annual progress reports for 1996 and 1997..$^{11,12}$ The presentation of our results on zircon follows after a short characterization of other waste forms potentially suitable for the immobilization of excess weapons-grade plutonium and plutonium wastes.

\section{Ceramic Waste Form Candidates}

The most promising mineral host phases for $\mathrm{Pu}$ include apatite, pyrochlore, zirconolite, monazite, zircon, and zirconia. The physical and chemical properties of these minerals, except zirconia, were reviewed recently. ${ }^{13}$ 


\section{Pyrochlore and zirconolite}

A pyrochlore/zirconolite ceramic, containing other phases such as brannerite, actinide oxides and rutile, has been selected for plutonium wastes in the United States ${ }^{10}$ and is currently under development at the Lawrence Livermore National Laboratory.

Pyrochlore is a derivative of the fluorite structure type. In the general formula $\mathrm{A}_{2} \mathrm{~B}_{2} \mathrm{X}_{6} \mathrm{Y}$ larger cations are in the A-site (Na, $\mathrm{Ca}, \mathrm{U}, \mathrm{Th}, \mathrm{Y}$, and $\mathrm{REE}$ ) and smaller, higher, valence cations are preferably in the $\mathrm{B}$-site $\left(\mathrm{Nb}, \mathrm{Ta}, \mathrm{Ti}, \mathrm{Zr}, \mathrm{Fe}^{3+}\right)$. Pyrochlore structure types are host phases for actinides. The pyrochlore phase $\mathrm{Gd}_{2} \mathrm{Ti}_{2} \mathrm{O}_{7}$ has been extensively studied in terms of radiation damage as they become fully amorphous at a dose of $3.1 \times 10^{18}$ a-decay events/g. ${ }^{14,15}$ The crystalline-to-amorphous transition is accompanied by a factor of 50 decrease in chemical durability. Pyrochlores occur naturally with up to $30 \%$ by weight of uranium in the $\mathrm{A}$-site.

Zirconolite $\left(\mathrm{CaZrTi}_{2} \mathrm{O}_{7}\right)$ is one of the three main phases in Synroc, the most extensively studied ceramic waste form for high-level radioactive waste. ${ }^{6}$ Monoclinic zirconolite is a fluorite-derivative structure closely related to pyrochlore. Zirconolite is the primary actinide host in Synroc with the actinides accommodated in the A-site. Radiation effects in zirconolite have been studied extensively on ${ }^{238} \mathrm{Pu}$-substituted and ${ }^{244} \mathrm{Cm}$-doped samples. ${ }^{15}$

Natural occurrences of zirconolite are rare, but samples have been studied extensively. ${ }^{16-19}$ There are samples fully amorphized by radiation but zirconolite is less susceptible to radiation-induced amorphization than pyrochlore.

\section{Apatite}

Apatite is a relatively abundant natural mineral, $\mathrm{Ca}_{10}\left(\mathrm{PO}_{4}\right)_{6}(\mathrm{~F}, \mathrm{OH})_{2}$. It has been observed as a crystallization product in a borosilicate glass nuclear waste form ${ }^{20}$, in a glass ceramic nuclear waste form, ${ }^{21}$ and in a multiphase ceramic nuclear waste form. ${ }^{22}$ Apatite has been suggested as a host phase for actinides. The compositions discovered in radioactive waste forms are $\mathrm{Ca}_{4-x} \mathrm{REE}_{6+x}\left(\mathrm{SiO}_{4}\right)_{6-y}\left(\mathrm{PO}_{4}\right)_{y}(\mathrm{~F}, \mathrm{OH}, \mathrm{O})_{2}$, where $\mathrm{REE}=\mathrm{La}, \mathrm{Ce}$, $\mathrm{Pr}, \mathrm{Nd}, \mathrm{Pm}, \mathrm{Sm}, \mathrm{Eu}$, and $\mathrm{Gd})$. Actinides such as Th, U, Pu, $\mathrm{Cm}$ can be accommodated on REE sites. Apatites with at least 6 wt.\% of ${ }^{244} \mathrm{Cm}$ and ${ }^{240} \mathrm{Pu}$ have been identified in glass. ${ }^{20}$ 
Natural apatites contain appreciable amounts of uranium and thorium. Some samples are partially metamict as due to self-irradiation. ${ }^{23,24}$ Apatites formed in the Oklo reactor region in Gabon, Africa, and incorporated ${ }^{239} \mathrm{Pu}$ as evidenced by their ${ }^{235} \mathrm{U}$ concentration. Uranium has been retained for 2 billion years. ${ }^{25}$

\section{Monazite}

Monazite is a mixed lanthanide phosphate, $\mathrm{LnPO}_{4}(\mathrm{La}, \mathrm{Ce}, \mathrm{Nd}, \mathrm{Gd}$ etc.). It has been proposed and studied as a host phase for high-level radioactive waste. ${ }^{26}$ Monazite can accommodate, e.g., up to $20 \mathrm{wt} . \%$ of Savannah River high-level defense waste, and exhibit leach rates several orders of magnitude lower than typical borosilicate glass waste forms.

Natural samples can contain up to $27 \%$ by weight of uranium and thorium together. The mineral is fairly abundant in nature. The material can be amorphized by external irradiation ${ }^{27}$ but is found in nature only in the crystalline state, because it has a relatively low annealing temperature (full recovery of crystallinity at $300^{\circ} \mathrm{C}$ after 20 hours).

\section{Zirconia}

Zirconia, $\mathrm{ZrO}_{2}$, occurs in nature in its monoclinic modification as baddeleyite. There are two isomorphs, a tetragonal and a cubic modification. In the cubic modification the cations are arranged in a face-centered lattice (fluorite structure). The anions are in simple cubic packing with cations occupying the void at the centers of alternating cubic interstices. $\mathrm{ZrO}_{2}$ can be stabilized in the cubic structure either by tetra-, tri-, or divalent cations replacing $\mathrm{Zr}$. Tetravalent substitutes are $\mathrm{Zr}, \mathrm{Hf}, \mathrm{Ce}^{4+}, \mathrm{U}^{4+}, \mathrm{Th}$, and $\mathrm{Pu}^{4+}$. Trivalent substitutes are rare earth elements $\mathrm{Y}, \mathrm{Gd}, \mathrm{Er}$, etc., $\mathrm{Al}, \mathrm{Fe}$, and others. Divalent substitutes are $\mathrm{Ca}, \mathrm{Mg}$, etc. When $\mathrm{Zr}^{4+}$ is replaced by tri- or divalent cations, oxygen vacancies are introduced to maintain electrical neutrality.

After having evaluated the solid solution properties of zirconia, we believe that a single phase ceramic waste form can be produced accommodating all constituents found in excess weapons plutonium wastes. ${ }^{28}$ Zirconia is also expected to dissolve a variety of neutron absorbers, such as $\mathrm{Hf}, \mathrm{Gd}$, or Er.

Data reviewed by Naguib and Kelly demonstrate the high resistance of zirconia against amorphization. ${ }^{29}$ Ion irradiation studies did not show amorphization in ytrium stabilized zirconia up to very high doses..$^{30}$ For example, no amorphization was observed 
after irradiation with $400 \mathrm{keV} \mathrm{Xe} e^{+}$ions up to a dose of 110 displacement per atom (dpa) at $90^{\circ} \mathrm{C}^{31}$ and after irradiation with $240 \mathrm{keV} \mathrm{Xe} \mathrm{e}^{+}$ions at room temperature up to about 200dpa. ${ }^{30}$ A cubic zirconia solid solution $\left(\mathrm{Zr}_{0.75} \mathrm{Th}_{0.10} \mathrm{Y}_{0.10} \mathrm{Er}_{0.05}\right) \mathrm{O}_{1.925}$, was irradiated with $1.5 \mathrm{MeV} \mathrm{Xe}{ }^{+}$ions up to $25 \mathrm{dpa}$ at $-253^{\circ} \mathrm{C}$ and no amorphization was detected. ${ }^{30}$ Comparing the data on radiation damage in the review of candidate host phases for plutonium by Ewing et al. with that for zirconia, ${ }^{13}$ provides evidence that $\mathrm{ZrO}_{2}$ is by far the most radiation resistant ceramic host phase.

\section{Zircon}

Zircon, $\mathrm{ZrSiO}_{4}$, is an abundant mineral in nature. The zircon structure consists of triangular dodecahedral $\mathrm{ZrO}_{8}$ groups which form edge-sharing chains parallel to the $\mathrm{c}$-axis, and $\mathrm{SiO}_{4}$ tetrahedral monomers that form edge-sharing chains with alternating $\mathrm{ZrO}_{8}$ groups parallel to the c-axis. ${ }^{32}$ In natural zircon, $\mathrm{U}$ and $\mathrm{Th}$ replace $\mathrm{Zr}$ in low concentrations $(\leq 0.5$ wt.\%). Compositions of $\mathrm{ASiO}_{4}$ with $\mathrm{A}^{4+}=\mathrm{Zr}, \mathrm{Hf}, \mathrm{Th}, \mathrm{Pa}, \mathrm{U}, \mathrm{Np}, \mathrm{Pu}$, and $\mathrm{Am}$, respectively, have been synthesized. Four of these compounds occur naturally as hafnon, $\left(\mathrm{HfSiO}_{4}\right)$, zircon, coffinite $\left(\mathrm{USiO}_{4}\right)$, and thorite, $\left(\mathrm{ThSiO}_{4}\right)$.

Because of its abundance as an accessory mineral in igneous and metamorphic rocks and its extremely high chemical durability, zircon is by far the most often used material in geochronology. There are nearly 7000 publications in the geological literature alone (GeoRef), documenting its significance as a chemically closed system. Zircon's physical and chemical durability are such that individual grains can undergo many cycles of weathering and erosion followed by transport and deposition with little physical abrasion or chemical dissolution. Zircon is the oldest dated mineral on earth and in the universe. Ages up to 3.6 billion years were determined.

Zircon is found in nature in all structural states between fully crystalline and fully amorphous. The crystalline to amorphous transition is mainly due to $\alpha$-decay of ${ }^{235} \mathrm{U}$. Radiation damage $\mathrm{e}^{33-37}$ and annealing mechanisms ${ }^{38}$ have been studied in great detail.

Zircon has been suggested independently by Russian scientists ${ }^{39,40}$ and by Ewing, Lutze and Weber ${ }^{7}$ as a host phase for weapons plutonium. Beside the synthesis of pure $\mathrm{PuSiO}_{4}{ }^{41}$ zircon has been doped with 10 wt.\% plutonium ${ }^{7}$ using the sol-gel method. Solid state synthesis of zircon and its solid solutions with plutonium have been studied by hot isostatic pressing of powder mixtures by Huang and Spearing. ${ }^{42}$ Solubility limits were reported for zircon and coffinite and for zircon and thorite. ${ }^{43}$ Recently, synthesis of zircon and its solid solutions with $\mathrm{Ce}^{4+}, \mathrm{U}^{4+}$ and $\mathrm{Th}^{4+}$ were studied by sol-gel methods and 
solubility limits were established. There is complete miscibility between zircon and hafnon. ${ }^{44}$

Zircon is the host phase with the most detailed data base on radiation effects. Natural samples with uranium have been analyzed to evaluate waste form performance over the whole period of time it takes for ${ }^{239} \mathrm{Pu}\left(\mathrm{t}_{1 / 2}=2.4 \times 10^{4} \mathrm{yr}\right.$. $)$ and its daughter ${ }^{235} \mathrm{U}\left(\mathrm{t}_{1 / 2}=7 \times 10^{8} \mathrm{yr}\right.$. $)$ to decay to negligible concentrations.

\section{Zircon's chemical durability - previous work (literature)}

In this chapter we summarize briefly what was known about zircon's chemical durability before we made an attempt to measure its dissolution rate in water at elevated temperatures.

\subsection{Zircon dissolution kinetics and solubility studies}

A number of zircon dissolution studies have been conducted since the $1960 \mathrm{~s}^{46-51}$ A literature review was given in the previous reports. ${ }^{11,12}$ Here we will go into a more detailed consideration of Ewing's et al. and Tole's work on zircon dissolution in water and Ayers \& Watson's work on dissolution under supercritical conditions.

The leachability of both synthetic and natural zircon samples as a function of radiation damage was measured by Ewing et al. (1982). ${ }^{48}$ The total alpha-decay event dose of each sample received was either calculated from the uranium content and the age of the sample or was estimated from the density calculations of Holland and Gottfried (1955). ${ }^{37}$ The purpose of the study was to quantify the effect of radiation damage on the leach rate of zircon. The natural zircon samples were heterogeneous with regard to zonation and degree of fracture and contained inclusions of other phases (e.g. quartz, feldspar and uraninite). The synthetic zircon powders were crystalline and pure in that no unidentified diffraction maxima were observed in their X-ray diffraction patterns. Powdered samples (50-160 $\mu \mathrm{m}$ grains) were leached in a solution of $5 \mathrm{wt} \% \mathrm{KHCO}_{3}$ at $87 \pm 2^{\circ} \mathrm{C}$ for 9.9 days. Leachates were analyzed using inductively coupled plasma atomic emission spectrometry (ICP-AES).

The alpha-decay event doses and the measured leach rates for the zircon samples are shown in Table 1 . In addition to the radiation damaged samples, two crystalline zircon 
samples were leached for comparison. The alpha-decay event doses ranged from $6.02 \times 10^{16}$ to greater than $1 \times 10^{19}$ alpha decay events per gram. A plot of wt. $\%$ zircon dissolved, based on the $\mathrm{Zr}$ concentration in solution, is shown in Figure 1. For the first four samples for which alpha-decay dose was calculated, the wt. $\%$ of zircon dissolved increased from $1.57 \times 10^{-3}$ to $2.0 \times 10^{-2}$. The samples with estimated alpha-decay doses based on density measurement show a similar trend.

Table 1. Zircon leaching data results (from Ewing et al., 1982). ${ }^{48}$

\begin{tabular}{l|l|l}
\hline Sample number & Alpha dose $(1 / \mathrm{g})$ & Leach rate $\left(\mathrm{g} / \mathrm{m}^{2} /\right.$ day $)$ \\
7 & 0 & $3.4 \times 10^{-3}$ \\
$5 \mathrm{~b}$ & 0 & $3.2 \times 10^{-4}$ \\
$77-215$ & $6.0 \times 10^{16}$ & $2.9 \times 10^{-4}$ \\
RSD-9 & $3.30 \times 10^{17}$ & $1.9 \times 10^{-4}$ \\
$\# 3$ & $<2 \times 10^{18}$ & $2.2 \times 10^{-3}$ \\
$\# 17$ & $<2 \times 10^{18}$ & $1.5 \times 10^{-3}$ \\
DB-10 & $6.49 \times 10^{18}$ & $9.2 \times 10^{-4}$ \\
M-83-NM & $9.44 \times 10^{18}$ & $2.3 \times 10^{-3}$ \\
$\# 4 \mathrm{a}$ & $>1 \times 10^{19}$ & $1.8 \times 10^{-2}$ \\
$\# 4 \mathrm{~b}$ & $>1 \times 10^{19}$ & $2.4 \times 10^{-3}$ \\
\#Cl & $>1 \times 10^{19}$ & $2.1 \times 10^{-2}$ \\
\hline
\end{tabular}

When all samples are considered there is an increase in the wt.\% of zircon dissolved of two orders of magnitude, and an increase in the leach rate of between one and two orders of magnitude (Figure 2).

Ewing's et al. study identified and quantified the increase in leach rate as a function of radiation damage due to alpha-decay event damage. The effect of radiation damage on chemical durability measured in these experiments may, to a certain extent, be obscured by increased surface area caused by microfractures or local geochemical alteration in zircon samples; however, the amount of zircon dissolved was not dramatically affected by differences in the surface area of crystals from different size fractions. 
Ayers \& Watson (1991) $)^{51}$ determined the solubility of zircon in supercritical aqueous fluids $\left(\mathrm{P}=10-30 \mathrm{kbar} ; \mathrm{T}=800-1200^{\circ} \mathrm{C}\right)$ by measuring mass loss in their zircon samples. At standard conditions the neutral tetrahydroxide species, $\mathrm{Zr}(\mathrm{OH})_{4}^{0}$, is stable for dissolved $\mathrm{ZrO}_{2}$ over a range of $\mathrm{pH}$ from 3 to 11 at $\log [\mathrm{Zr}]=-4$. Solubilities are, therefore, largely independent of $\mathrm{pH}$ at STP. Ayers \& Watson's (1991) ${ }^{51}$ results for the amount of

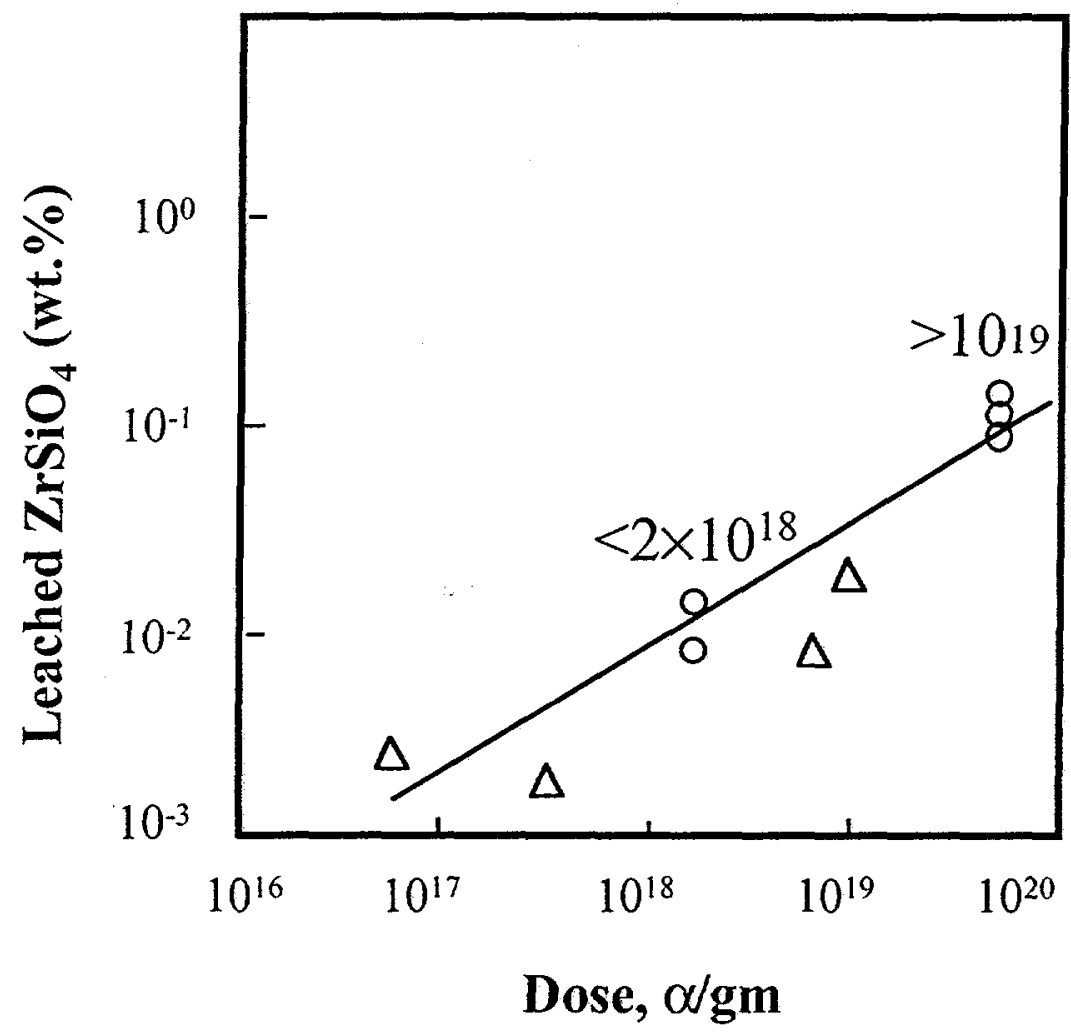

Figure. 1. A plot of wt.\% zircon dissolved, based on $\mathrm{Zr}$ in solution, vs. alpha-decay event dose. The triangles indicate samples for which alpha-decay dose was calculated based on U-content and age. The open circles indicate samples for which the alpha-decay event dose is estimated based on density (Ewing et al., 1982, ref. 48).

zircon dissolved in quenched silicate-saturated aqueous solutions suggest that the solubility of $\mathrm{ZrO}_{2}$ in the fluid is between 700 and $1800 \mathrm{ppm}$ in equilibrium with zircon and quartz. In pure $\mathrm{H}_{2} \mathrm{O}$ at $10 \mathrm{kbar}$ and $1000^{\circ} \mathrm{C}$, holding the sample to water volume ratio constant, the amount of zircon dissolved was $5.3 \mathrm{wt} . \%$. In water at $20 \mathrm{kbar}$ and $1100^{\circ} \mathrm{C}$ the amount of zircon dissolved remained essentially the same, $5.2 \mathrm{wt} . \%$. This suggests that temperature and pressure have little effect. Adding $\mathrm{CO}_{2}$ to the fluid decreased the solubility to below the detection limit. Ayers and Watson concluded that the solubility of 
zircon in quartz-saturated fluids is very low (on the order of $1,000 \mathrm{ppm}$ ), regardless of whether $\mathrm{HCl}$ or $\mathrm{NaCl}$ is present.

The only study of the kinetics of zircon dissolution at low temperatures $\left(25-80^{\circ} \mathrm{C}\right)$ in water was conducted by Tole (1985, ref. 50). The experiment involved static leaching of 1 gram each of powdered crystalline and metamict zircon in 1 liter of water at temperatures 25,60 and $80^{\circ} \mathrm{C}$. The $\mathrm{pH}$ was monitored and adjusted to maintain $\mathrm{pH}=5$ by addition of $\mathrm{HCl}$ or $\mathrm{NH}_{4} \mathrm{OH}$, as required. Over a period of up to 1500 hours, samples were taken and analyzed for $\mathrm{U}, \mathrm{Zr}$ and $\mathrm{Si}$. The metamict zircon contained impurities of

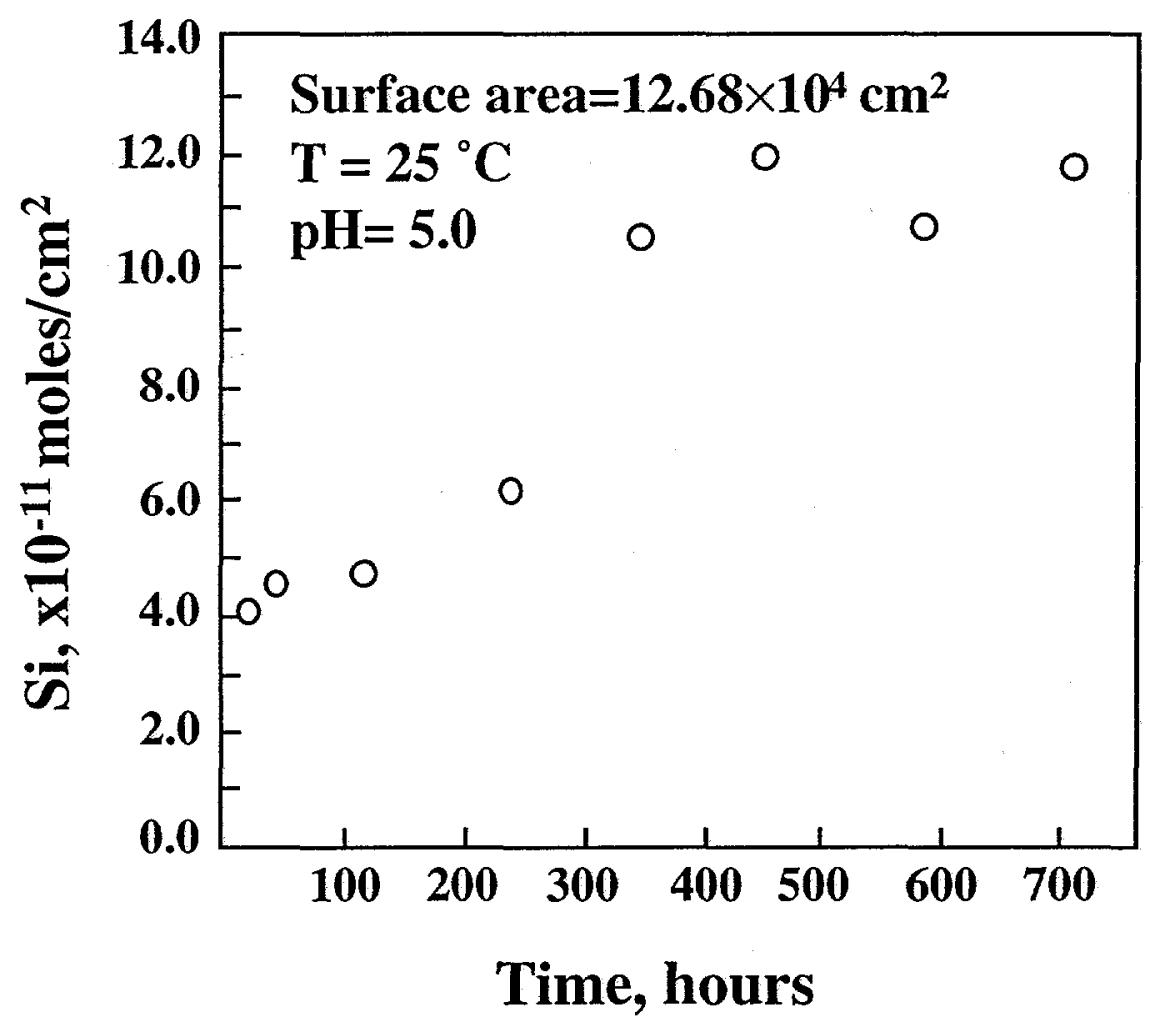

Figure 2. Si mass loss of amorphous zircon as a function of time at $25^{\circ} \mathrm{C}$ (Tole, 1985, ref. 50).

$\mathrm{HfO}_{2}$ (5.13 wt.\%), $\mathrm{Yb}_{2} \mathrm{O}_{3}$ (4.63 wt.\%), $\mathrm{FeO}$ (4.06 wt.\%), $\mathrm{CaO}$ (1.82 wt.\%), $\mathrm{ThO}_{2}$ (1.04 wt.\%) and $\mathrm{UO}_{2}(0.85$ wt.\%). The zircon samples were ground in an agate mortar and sieved to two mesh sizes, $125-250 \mu \mathrm{m}$ and 250-500 $\mu \mathrm{m}$ (BET technique). Samples (10 $\mathrm{mL}$ ) were drawn periodically over the course of the experiments. Two drops of $48 \% \mathrm{HF}$ were added to suppress precipitation of $\mathrm{Zr}$ and Si species. 


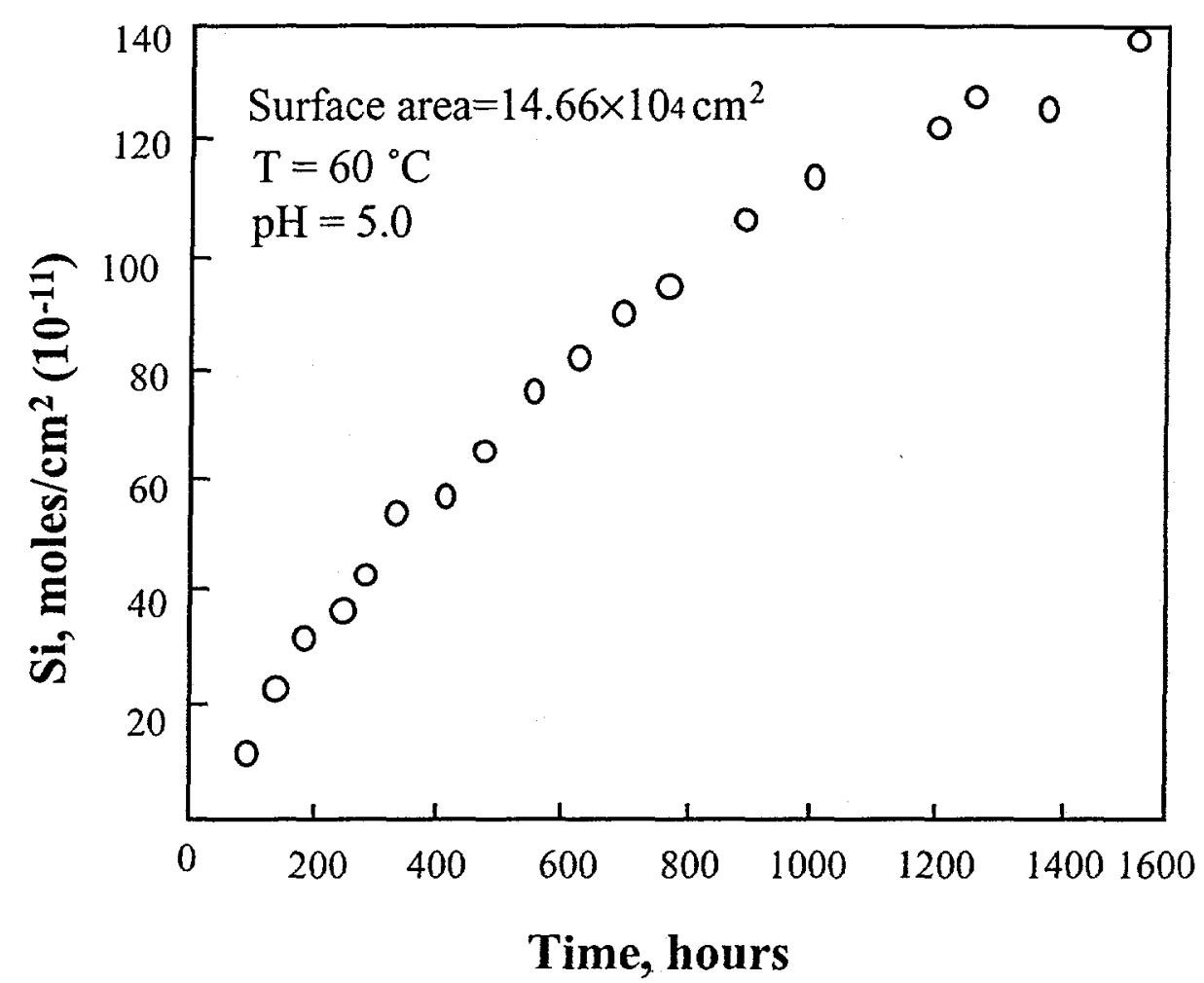

Figure 3. Si mass loss for amorphous zircon as a function of time (Tole, 1985, ref. 50).

Plasma emission spectrometry was used to determine the concentrations of both $\mathrm{Zr}$ and $\mathrm{Si}$ in solution. The detection limit for both elements was established at $0.05 \mathrm{ppm}$. The results of this experiment showed that, for the amorphous samples, the $\mathrm{Si}$ concentration increased with time. $\mathrm{Zr}$ was not detectable. Neither Si nor $\mathrm{Zr}$ were detected in experiments with crystalline zircon.

Tole concluded that the dissolution of amorphous zircon can be described by a first-order reaction. The results for the amorphous zircon experiments showed increasing $\mathrm{Si}$ concentrations over time. The Si release profile at $25^{\circ} \mathrm{C}$ is shown in Figure 2. These data yield a leach rate of $2.24 \times 10^{-19} \mathrm{moles} / \mathrm{cm}^{2} / \mathrm{hr}$. This experiment was conducted using $125-250 \mu \mathrm{m}$ zircon grains with a measured BET surface area of $12.68 \times 10^{4} \mathrm{~cm}^{2} / \mathrm{g}$. The BET surface areas for $250-500 \mu \mathrm{m}$ grains were used in the 60 and $80^{\circ} \mathrm{C}$ tests to calculate the release of $\mathrm{Si}$.

The Si release profile for $60^{\circ} \mathrm{C}$ is shown in Figures 3. Tole attributes the initial rapid rates to dissolution of active surfaces and ignored these data in calculating the leach rates. The linear portion of the data were used. For the $60^{\circ} \mathrm{C}$ experiment, the curve from 
144 to $622 \mathrm{hrs}$. yielded a leach rate of $1.19 \times 10^{-13} \mathrm{moles} / \mathrm{cm}^{2} /$ hour $\left(5 \times 10^{-6} \mathrm{gm}^{-2} \mathrm{~d}^{-1}\right)$. For the $80^{\circ} \mathrm{C}$ run, data between 70 to 489 hours yielded a leach rate of $3.52 \times 10^{-13} \mathrm{moles} / \mathrm{cm}^{2} /$ hour $\left(1.55 \times 10^{-5} \mathrm{gm}^{-2} \mathrm{~d}^{-1}\right)$. The dissolution reaction, based on Si release rates, has an activation energy of $53.6 \mathrm{~kJ} / \mathrm{mole}$. Tole concluded that, regardless of the mechanism of recrystallization proposed, crystalline zircon is thermodynamically stable in solution to such an extent that the concentrations of aqueous species remain well below his detection limit of $0.05 \mathrm{ppm}$.

Thermodynamic calculations show that at $25^{\circ} \mathrm{C}$, baddeleyite, $\mathrm{ZrO}_{2}$, starts to precipitate when $\mathrm{Zr}$ concentrations reach $0.06 \mathrm{ppb}$. Zircon starts to precipitate when $\mathrm{Si}$

Table 2. Summary of previous studies of zircon dissolution.*

\begin{tabular}{|c|c|c|c|c|c|c|c|c|c|c|c|c|}
\hline \multirow{2}{*}{$\begin{array}{l}\text { first } \\
\text { author }\end{array}$} & \multicolumn{2}{|c|}{ zircon } & \multicolumn{2}{|c|}{ medium } & \multirow{2}{*}{$\begin{array}{l}\mathrm{T} \\
\left({ }^{\circ} \mathrm{C}\right)\end{array}$} & \multicolumn{5}{|c|}{ element in solution } & \multirow{2}{*}{$\begin{array}{l}\text { leach rate } \\
\mathrm{g} / \mathrm{m}^{2} / \mathrm{d}\end{array}$} & \multirow{2}{*}{$\begin{array}{l}\mathrm{E}_{\mathrm{a}} \\
\mathrm{kJ} / \text { mole }\end{array}$} \\
\hline & met & $\mathrm{xal}$ & melt & $\mathrm{aq}$ & & $\mathrm{Zr}$ & $\mathrm{Si}$ & $\bar{U}$ & $\mathrm{Th}$ & $\mathrm{Pb}$ & & \\
\hline Pidgeon & $\mathrm{X}$ & & & $\bar{X}$ & 500 & & & $\mathrm{X}$ & $\mathrm{X}$ & $\mathrm{X}$ & & \\
\hline Prasad & $?$ & $?$ & & $\mathrm{X}$ & $?$ & & & $\mathrm{X}$ & $\mathrm{X}$ & & & \\
\hline Ewing & $\mathrm{X}$ & $\mathrm{X}$ & & $\mathrm{X}$ & 87 & $\mathrm{X}$ & & & & & $\begin{array}{l}9.2 \times 10^{-4} \\
1.8 \times 10^{-2}\end{array}$ & \\
\hline $\begin{array}{l}\text { Harriso } \\
\mathrm{n}\end{array}$ & & $\bar{X}$ & $\bar{X}$ & & $\begin{array}{l}1020 \\
1500\end{array}$ & $\bar{X}$ & & & & & & \\
\hline Ayers & $?$ & $?$ & & $\mathrm{X}$ & $\begin{array}{l}1000 \\
1100\end{array}$ & $\bar{X}$ & & & & & & \\
\hline Tole & $\mathrm{X}$ & $\mathrm{X}$ & & $\mathrm{X}$ & $\begin{array}{l}60 \\
80\end{array}$ & $\mathrm{X}$ & $\mathrm{X}$ & & & & $\begin{array}{l}5 \times 10^{-6} \\
1.55 \times 10^{-5}\end{array}$ & 53.6 \\
\hline
\end{tabular}

*The aqueous medium used by Ewing et al. (1982) was a $5 \mathrm{wt} . \% \mathrm{KHCO}_{3}$ solution. The aqueous medium used by Tole (1985, ref. 50) was $\mathrm{H}_{2} \mathrm{O}$.

concentrations reach $1.0 \mathrm{ppb}$. $\mathrm{Zr}$ was not detectable in solution, due to the precipitation of $\mathrm{ZrO}_{2}$. The $\mathrm{U}$ values were not systematic and no interpretation for the behavior of the $\mathrm{U}$ was offered. 
A summary of the previous work conducted on zircon dissolution is presented in Table 2. The structural state of the zircon studied, either metamict or crystalline, is indicated. The dissolution medium is indicated as either melt or aqueous. The temperature is given and the elements analyzed are noted. The studies are identified by the name of the first author. The symbol, $\mathrm{E}_{\mathrm{a}}$, refers to the activation energy for zircon hydration.

The few zircon solubility studies presented here, lead to the same conclusion: zircon is a chemically durable mineral. Two studies highlighted the dependence of zircon leachability on radiation damage. Ewing et al. $(1982)^{48}$ found that total metamictization $\left(7 \times 10^{15}\right.$ alpha-decay events $\left./ g\right)$ results in a two order of magnitude increase in the leach rate over that of crystalline zircon. Pidgeon et al. $(1967)^{46}$ found considerable lead loss from metamict zircon at $500^{\circ} \mathrm{C}$ in supercritical water. The Tole study failed to measure the dissolution rate of crystalline zircon in static leach tests. However, the precipitation of $\mathrm{ZrO}_{2}$ was discovered by Tole, and this limits $\mathrm{Zr}$ in solution to below his detection limit. One important conclusion from these results is that the secondary precipitation of $\mathrm{ZrO}_{2}$ limits the effectiveness of static leach methods in quantifying leach rates for zircon.

\subsection{Thermodynamics of Zircon Dissolution}

In order to determine the experimental conditions and analytical methods necessary to quantify zircon dissolution, the free energy of formation values, $\Delta G_{f}$, was used to calculate expected solution concentrations of $\mathrm{Zr}$ and Si-hydrolysis species. Tole $(1985)^{50}$ used the $\Delta \mathrm{G}_{\mathrm{f}}$ for $\mathrm{ZrSiO}_{4}$ and $\mathrm{H}_{2} \mathrm{O}$ to calculate the saturation concentrations of $\mathrm{H}_{4} \mathrm{SiO}_{4}$ and $\mathrm{Zr}(\mathrm{OH})_{4}$ over zircon. Tole concluded from his calculations that an analytical method capable of detecting $\mathrm{Zr}$ and Si species on the order of $0.001 \mathrm{ppb}$ was required in order to quantify the dissolution of crystalline zircon.

We conducted a literature review to determine if Tole's conclusions were consistent with the available thermodynamic data, because Tole did not provide the thermodynamic data necessary to confirm his calculations.

\subsubsection{Thermal stability and thermodynamics of zircon}

Since the $1950 \mathrm{~s}$, six studies have been conducted to measure the thermodynamic constants of formation and dissociation of zircon or to measure the thermal stability of 
zircon. ${ }^{52-57}$ The first study (Curtis \& Sowman, 1953) ) $^{52}$ used X-ray diffraction analysis to determine the temperature at which zircon decomposes into its constituent oxides, $\mathrm{ZrO}_{2}$ and $\mathrm{SiO}_{2}$. The process of the breakdown of zircon began slowly at $1579^{\circ} \mathrm{C}$ after approximately 2 hours. The decomposition products were monoclinic $\mathrm{ZrO}_{2}$ and amorphous $\mathrm{SiO}_{2}$. The thermal decomposition of zircon rapidly increased above $1635^{\circ} \mathrm{C}$. At $1746^{\circ} \mathrm{C}, 5 \mathrm{Vol} \% \%$ free zirconia formed and $95 \mathrm{Vol} \%$ free zirconia formed at $1857^{\circ} \mathrm{C}$. Decomposition was complete at $1857^{\circ} \mathrm{C}$ for one run held at temperature for 6 hours. The formation and decomposition of zircon was reinvestigated by Kanno (1989). ${ }^{56}$ Kanno pointed out that zircon does not begin to decompose below $1650^{\circ} \mathrm{C}$; rather zircon decomposes at $1700^{\circ} \mathrm{C}$ to form $\mathrm{ZrO}_{2}+\mathrm{SiO}_{2}$ detected at room temperature as monoclinic $\mathrm{ZrO}_{2}$ and $\mathrm{SiO}_{2}$ glass.

The most recent study of the thermodynamic stability of zircon was conducted by Ellison and Navrotsky (1992). ${ }^{57}$ Recent techniques in high-temperature oxide-melt solution calorimetry were applied to measure the enthalpy of formation of zircon. The results were then used to test the validity of the earlier studies.

Solution calorimetry in molten $2 \mathrm{PbO} \mathrm{B}_{2} \mathrm{O}_{3}$ at $977 \mathrm{~K}\left(704^{\circ} \mathrm{C}\right)$ was used to obtain the heat of reaction of zircon from quartz $\left(\mathrm{SiO}_{2}\right)$ and baddeleyite $\left(\mathrm{ZrO}_{2}\right)$. A modified twin Calvet-type calorimeter was used in which a small sample (5 to $50 \mathrm{mg}$ ) was suspended one $\mathrm{cm}$ above the surface of $30 \mathrm{~g}$ of the $2 \mathrm{PbO} \cdot \mathrm{B}_{2} \mathrm{O}_{3}$ solvent. This experimental configuration allowed the sample to reach thermal equilibrium at the test temperature, $704^{\circ} \mathrm{C}$.

Table 3. The regression coefficients for equation (3) for $\mathrm{ZrO}_{2}$ and $\mathrm{ZrSiO}_{4}$.

\begin{tabular}{|l|l|l|l|l|l|}
\hline & $\mathrm{k}_{0}$ & $\mathrm{k}_{\mathrm{ln}}$ & $10^{-3} \mathrm{k}_{1}$ & $10^{-5} \mathrm{k}_{2}$ & $10^{-7} \mathrm{k}_{3}$ \\
\hline $\mathrm{ZrO}_{2}{ }^{*}$ & 724.238 & -77.489 & -144.945 & 368.489 & -412.690 \\
\hline $\mathrm{ZrO}_{2}{ }^{* *}$ & 74.825 & & & & \\
\hline $\mathrm{ZrSiO}_{4}$ & 233.424 & -11.257 & 13.962 & -268.773 & 510.140 \\
\hline
\end{tabular}

${ }^{*} 298 \mathrm{~K} \leq \mathrm{T}<1478 \mathrm{~K} .{ }^{* * T}>1478 \mathrm{~K}$.

The results of this study were determined by applying the equation:

$$
\Delta_{\mathrm{r}} \mathrm{H}_{977}\left(\mathrm{ZrSiO}_{4}\right)=\Delta_{\mathrm{s}} \mathrm{H}_{977}\left(\mathrm{SiO}_{2}\right)+\Delta_{\mathrm{s}} \mathrm{H}_{977}\left(\mathrm{ZrO}_{2}\right)-\Delta_{\mathrm{s}} \mathrm{H}_{977}\left(\mathrm{ZrSiO}_{4}\right)
$$


where $\Delta_{s} H_{T}$ of a given species is the molar enthalpy of dissolution of that species at the designated temperature. At any other temperature the enthalpy of reaction can be determined by:

$$
\Delta_{\mathrm{r}} \mathrm{H}_{\mathrm{T}}\left(\mathrm{ZrSiO}_{4}\right)=\Delta_{\mathrm{r}} \mathrm{H}_{977}\left(\mathrm{ZrSiO}_{4}\right)+\int_{977}^{\mathrm{T}} \Delta \mathrm{C}_{\mathrm{p}} \mathrm{dT}
$$

where $\Delta \mathrm{C}_{\mathrm{p}}=\mathrm{C}_{\mathrm{p}}\left(\mathrm{ZrSiO}_{4}\right)-\mathrm{C}_{\mathrm{p}}\left(\mathrm{ZrO}_{2}\right)-\mathrm{C}_{\mathrm{p}}\left(\mathrm{SiO}_{2}\right)$. These data were regressed using an equation for the heat capacity of the form:

$$
\mathrm{C}_{\mathrm{p}}=\mathrm{k}_{0}+\mathrm{k}_{\ln } \ln \mathrm{T}+\left(\mathrm{k}_{1} / \mathrm{T}\right)+\left(\mathrm{k}_{2} / \mathrm{T}^{2}\right)+\left(\mathrm{k}_{3} / \mathrm{T}^{3}\right)
$$

Table 4. $\mathrm{H}_{\mathrm{T}}-\mathrm{H}_{298}$ and $\mathrm{S}_{\mathrm{T}}{ }^{0}$ of $\mathrm{ZrO}_{2}$ and $\mathrm{ZrSiO}_{4} \cdot * * \Delta \mathrm{H}_{\text {trans }}{ }^{1478}\left(\alpha-\mathrm{ZrO}_{2} \rightarrow \beta-\mathrm{ZrO}_{2}\right)=4.137$ $\mathrm{kJ} /$ mole by extrapolation of the data above $1480 \mathrm{~K}$ and below $1460 \mathrm{~K}$.

\begin{tabular}{|l|l|l|l|l|}
\hline & \multicolumn{3}{|l|}{} & $\mathrm{ZrO}_{2}$ \\
\hline $\mathrm{T}(\mathrm{K})$ & $\begin{array}{l}\mathrm{H}_{\mathrm{T}}-\mathrm{H}_{298} \\
(\mathrm{~kJ} / \text { mole })\end{array}$ & $\begin{array}{l}\mathrm{S}_{\mathrm{T}}{ }^{0} \\
(\mathrm{~J} / \mathrm{K} \cdot \text { mole })\end{array}$ & $\begin{array}{l}\mathrm{H}_{\mathrm{T}}-\mathrm{H}_{298} \\
(\mathrm{~kJ} / \text { mole })\end{array}$ & $\begin{array}{l}\mathrm{S}_{\mathrm{T}}{ }^{0} \\
(\mathrm{~J} / \mathrm{K} \cdot \text { mole })\end{array}$ \\
\hline 298.15 & 0.000 & 50.359 & 0.000 & 84.026 \\
300 & 0.099 & 50.703 & 0.192 & 84.683 \\
400 & 6.135 & 68.018 & 10.962 & 115.616 \\
500 & 12.674 & 82.592 & 22.845 & 142.083 \\
600 & 19.548 & 95.116 & 35.790 & 165.659 \\
700 & 26.699 & 106.136 & 49.475 & 186.743 \\
800 & 34.069 & 115.974 & 63.651 & 205.666 \\
900 & 41.599 & 124.841 & 78.149 & 222.739 \\
977 & 47.472 & 131.102 & 89.459 & 234.797 \\
1000 & 49.235 & 132.886 & 92.856 & 238.234 \\
1100 & 56.933 & 140.223 & 107.698 & 252.379 \\
1200 & 64.657 & 146.943 & 122.623 & 265.364 \\
1300 & 72.375 & 153.121 & 137.595 & 277.348 \\
1400 & 80.062 & 158.818 & 152.589 & 288.460 \\
1478 & 86.025 & 162.963 & & \\
$1478 * *$ & 92.111 & 167.080 & & \\
1500 & 93.754 & 168.184 & 167.589 & 298.809 \\
1600 & 101.420 & 173.131 & 182.580 & 308.484 \\
1700 & 108.928 & 177.683 & 197.555 & 317.563 \\
1800 & 116.252 & 181.870 & 212.506 & 326.109 \\
1900 & 123.468 & 185.772 & 227.430 & 334.177 \\
2000 & 130.369 & 189.313 & 242.322 & 341.816 \\
\hline
\end{tabular}


Zirconia undergoes a phase transformation at $1478 \mathrm{~K}$, so separate regressions were conducted through 1460 and above $1480 \mathrm{~K}$. Ellison and Navrotsky obtained the regression coefficients reported in Table 3.

The same heat capacity data were used to calculate $\mathrm{S}_{\mathrm{T}}{ }^{0}\left(\mathrm{ZrO}_{2}\right)$ and $\mathrm{S}_{\mathrm{T}}{ }^{0}\left(\mathrm{ZrSiO}_{4}\right)$. The heat content and the entropy data are summarized in Table 4 . The values for the heat content of the silica polymorphs was taken from Richet et al. (1982). ${ }^{58}$

These data were then used to calculate the enthalpy and the free energy of reaction of zircon formation from its constituent oxides:

$$
\begin{gathered}
\Delta_{\mathrm{r}} \mathrm{H}_{298}\left(\mathrm{ZrSiO}_{4}\right)=-25.9( \pm 1.9) \mathrm{kJ} \\
\Delta_{\mathrm{r}} \mathrm{G}_{298}\left(\mathrm{ZrSiO}_{4}\right)=-23.6( \pm 1.9) \mathrm{kJ}
\end{gathered}
$$

This agrees with the range of values determined by Schuiling et al. (1976). ${ }^{55}$

$$
-28.5<\Delta_{\mathrm{r}} \mathrm{G}_{298}\left(\mathrm{ZrSiO}_{4}\right)<-20.7 \mathrm{~kJ}
$$

Standard state enthalpies and free energies of formation of quartz and baddeleyite were taken from the Janaf Thermochemical Tables (Chase et al., 1985) ${ }^{59}$ and used by Ellison and Navrotsky $(1992)^{57}$ to determine the enthalpy and the free energy of formation of zircon from the elements:

$$
\begin{aligned}
& \Delta_{\mathrm{f}} \mathrm{H}^{0}{ }_{298}\left(\mathrm{ZrSiO}_{4}\right)=-2034.2( \pm 3.1) \mathrm{kJ} \\
& \Delta_{\mathrm{f}} \mathrm{G}^{0}{ }_{298}\left(\mathrm{ZrSiO}_{4}\right)=-1919.8 \mathrm{~kJ}
\end{aligned}
$$

\subsubsection{Solubility of zircon - a closer look at Tole's study}

The main obstacle to quantifying the dissolution kinetics of zircon is the detection of species released into solution. An early attempt to model the chemical dissolution of zircon was unsuccessful due to the presence of baddeleyite, $\mathrm{ZrO}_{2}$, and zircon as solubility limiting phases (Tole, 1985).$^{50}$ Two reactions are important in this model:

$$
\mathrm{ZrSiO}_{4}+4 \mathrm{H}_{2} \mathrm{O}=\mathrm{Zr}(\mathrm{OH})_{4}+\mathrm{H}_{4} \mathrm{SiO}_{4} \quad \mathrm{~K}_{\mathrm{eq}}=2.48 \times 10^{-17}
$$

and

$$
\mathrm{Zr}(\mathrm{OH})_{4}=\mathrm{ZrO}_{2}+2 \mathrm{H}_{2} \mathrm{O} \quad \mathrm{K}_{\mathrm{eq}}=10^{9.168}
$$

Throughout this section, thermodynamic values are for standard pressure and temperature conditions, except where noted.

Combined, reactions 9 and 10 control the concentrations of $\mathrm{Si}$ and $\mathrm{Zr}$ in solution.

From reaction $(9), \quad \mathrm{K}_{\mathrm{eq}}=\left[\left(\mathrm{a}_{\mathrm{Zr}(\mathrm{OH}) 4}\right)\left(\mathrm{a}_{\mathrm{H} 4 \mathrm{SiO} 4}\right)\right] /\left[\left(\mathrm{a}_{\mathrm{ZrSiO} 4}\right)\left(\mathrm{a}_{\mathrm{H} 2 \mathrm{O}}^{4}\right)\right]=2.48 \times 10^{-17}$ and 
$\mathrm{a}_{\mathrm{ZrSiO4}}=\mathrm{a}_{\mathrm{H} 2 \mathrm{O}}^{4}=1$, the maximum concentration for $\mathrm{H}_{4} \mathrm{SiO}_{4}=3.63 \times 10^{-8} \mathrm{M}$. From reaction (10), $\mathrm{K}_{\mathrm{eq}}=\left[\left(\mathrm{a}_{\mathrm{ZrO2}}\right)\left(\mathrm{a}_{\mathrm{H} 2 \mathrm{O}}^{2}\right)\right] /\left(\mathrm{a}_{\mathrm{ZrOH} / 4}\right)=10^{9.168}$ and $\mathrm{a}_{\mathrm{ZrO2}}=\mathrm{a}^{2}{ }_{\mathrm{H} 2 \mathrm{O}}=1$, the maximum concentration for $\mathrm{Zr}(\mathrm{OH})_{4}=6.79 \times 10^{-10} \mathrm{M}$.

Tole based his calculations on $\mathrm{Zr}$-hydrolysis data taken from the Handbook of Thermodynamic Data (Naumov et al., 1974) ${ }^{60}$ However, attempts to repeat and confirm his values using these data, including the value for silicic acid given in the Handbook, were unsuccessful.

Applying these data to reaction (9), $\Delta \mathrm{G}_{\mathrm{rxn}}$ is;

$$
\Delta \mathrm{G}_{\mathrm{rxn}}=-2.303 R T \log \mathrm{K}_{\mathrm{eq}}
$$

and the $\mathrm{K}_{\mathrm{eq}}$ for reaction (9) is $\mathrm{K}_{\mathrm{eq}(\mathrm{rxn} 9)}=1.65 \times 10^{-5}$. This value differs by twelve orders of magnitude from the value reported by Tole. Attempts to recreate Tole's value for $\mathrm{K}_{\mathrm{eq}}$ for reaction (10) were also unsuccessful. Using the data by Naumov et al. (1974) $)^{60}$ and equation (11) we obtain:

$$
\Delta \mathrm{G}_{(\mathrm{rxn} 10)}=-29.5 \mathrm{~kJ} / \mathrm{mole}
$$

and $\mathrm{K}_{\mathrm{eq( \textrm {r } \times n 1 0 )}}=1.47 \times 10^{5}$.

This value differs by 4 orders of magnitude from the value reported by Tole. A possible explanation for the difference in the $\mathrm{K}_{\text {eq(xnn) }}$ is that Tole did not take the $\Delta \mathrm{G}_{f}$ value for silicic acid from the Handbook of Thermodynamic Data. The $\Delta \mathrm{G}_{\mathrm{f}(\mathrm{H} 4 \mathrm{SiO4)}}$ value he might have used can be calculated from his reported $\mathrm{K}_{\mathrm{eq}(\mathrm{x} \times \mathrm{n})}=2.48 \times 10^{-17}$ and is -1242.45 $\mathrm{kJ} /$ mole. A search of the thermodynamic literature revealed variations in the reported free energy of formation for silicic acid of up to $60 \mathrm{~kJ} / \mathrm{mole}$.

\subsubsection{The $\mathrm{U}-\mathrm{Zr}$ analogy}

The evaluation of the thermodynamic properties of $\mathrm{Zr}^{4+}$ oxides and hydroxides uncovers problems which are analogous to problems related to $\mathrm{U}^{4+}$ oxides and hydroxides. $\mathrm{Zr}^{4+}$ is a highly charged cation which hydrolyzes in acidic solutions and exists primarily as $\mathrm{Zr}(\mathrm{OH})_{4}{ }^{0}$, not as a free cation, in aqueous solutions. The oxide phase, $\mathrm{ZrO}_{2(\mathrm{~s})}$, has a high interfacial energy, similar to the interfacial energy of $\mathrm{UO}_{2(\mathrm{~s})}(\mathrm{J}$. Bruno, personal communication). ${ }^{61}$ As a result, these oxide phases are readily hydrated when in contact with water. Bruno reviewed the data available in the literature for the reaction:

$$
\mathrm{Zr}(\mathrm{OH})_{4(\mathrm{~S})}+4 \mathrm{H}^{+}=\mathrm{Zr}^{4+}+4 \mathrm{H}_{2} \mathrm{O}
$$


Bruno extrapolated the solubility coefficient reported by Bilinski et al. (1966) ${ }^{62}$ for the equilibrium determined in $1 \mathrm{M} \mathrm{NaClO}_{4}$ to the infinite dilution standard state using the SIT approach described by Grenthe et al. (1992). ${ }^{63}$ Bruno used the following interaction coefficients: $\varepsilon\left(\mathrm{H}^{+}, \mathrm{ClO}_{4}^{-}\right)=0.14 \quad$ (Grenthe et al., 1992); ${ }^{63} \varepsilon\left(\mathrm{Zr}^{4+}, \mathrm{ClO}_{4}{ }^{-}\right)=0.76$ (from the analogous $\mathrm{U}^{4+}$ cation).

Bruno obtained the $\log \mathrm{K}_{\mathrm{s} 0}$ for the infinite dilution standard state for freshly precipitated $\mathrm{Zr}(\mathrm{OH})_{4(\mathrm{~S})}$ of 1.6. Bruno selected the $\Delta \mathrm{G}_{\mathrm{f}(298.15 \mathrm{~K})}$ for $\mathrm{Zr}(\mathrm{OH})_{4(\mathrm{~S})}$ reported by Slobodov et al. $(1992)^{64},-1439.80 \mathrm{~kJ} / \mathrm{mole}$, and together with the well known values for $\Delta \mathrm{G}_{\mathfrak{f}(298.15 \mathrm{~K})}$ of $\mathrm{H}_{2} \mathrm{O},-237.140 \mathrm{~kJ} / \mathrm{mole}, \mathrm{H}^{+}, 0 \mathrm{~kJ} /$ mole and $\mathrm{Zr}^{4+},-495.23 \mathrm{~kJ} / \mathrm{mole}$, he calculated a $\log \mathrm{K}_{\mathrm{s} 0}$ of 4.99 for reaction 10 . This value is in reasonable agreement with the $\mathrm{K}_{\text {eq(rnnlo) }}$ for $\mathrm{Zr}(\mathrm{OH})_{4}$ calculated by equation $12,1.47 \times 10^{5}$.

If we examine this value for the $\Delta \mathrm{G}_{\mathrm{f}(\mathrm{Zr}(\mathrm{OH}) 4)}(-1439.8 \mathrm{~kJ} / \mathrm{mole})$ by using the value for the $\Delta \mathrm{G}_{\mathrm{f}(\mathrm{ZrO2})}=-1042.90 \mathrm{~kJ} / \mathrm{mole}$ reported by Robie and Hemingway (1995) and Wagman et al. (1982), ${ }^{65}$ and Slobodov et al. (1992), ${ }^{64}$ we find that these values are not consistent with equation 10 . Using these values the $\Delta \mathrm{G}_{(\mathrm{rxn} 10)}$ can be calculated:

$$
\begin{aligned}
& \Delta \mathrm{G}_{(\mathrm{rxn} 10)}=-2.303 \mathrm{RT} 4.99=-28.4865 \mathrm{~kJ} / \mathrm{mole} \\
& \Delta \mathrm{G}_{\mathrm{f}(\mathrm{H} 2 \mathrm{O})}=-184.21 \mathrm{~kJ} / \mathrm{mole}
\end{aligned}
$$

This value for $\Delta \mathrm{G}_{\mathrm{f}(\mathrm{H} 2 \mathrm{O})}$ is inconsistent with the well established value of -237.140 $\mathrm{kJ} /$ mole. If we recalculate the value for the free energy of formation for $\mathrm{Zr}(\mathrm{OH})_{4}$ using the value for $\Delta \mathrm{G}_{\mathrm{f}(\mathrm{H} 2 \mathrm{O})}=-237.140 \mathrm{~kJ} / \mathrm{mole}$, we find $\Delta \mathrm{G}_{\mathrm{f}(\mathrm{Zr} \mathrm{OH}) 4)}=-1517.14 \mathrm{~kJ} / \mathrm{mole}$. Using this value for $\Delta \mathrm{G}_{\mathrm{f}\left(\mathrm{Z}_{\mathrm{rOH} / 4)}\right.}$ results in a calculated $\mathrm{K}$-value for reaction 10 of $10^{-5}$ which agrees with the $\mathrm{K}$-value calculated by equation 11 .

There is sufficient consistency in the thermodynamic literature to select the $\Delta \mathrm{G}_{\mathrm{f}(\mathrm{ZrOH}) 4 \mathrm{f}}=-1517.14 \mathrm{~kJ} / \mathrm{mole}$. This value is within $18 \mathrm{~kJ}$ of the value reported by Aja et al. $(1996),{ }^{67} \Delta \mathrm{G}_{\mathrm{f}(\mathrm{ZrOH}) 4)}=-1499.01 \mathrm{~kJ} / \mathrm{mole}$, the most recent source for these thermodynamic data. 
Table 5. The measured and extrapolated values for $\log \mathrm{K}_{\mathrm{s} 0}$ for reaction 10 as reported in the available literature (all measured by potentiometric titration method)

\begin{tabular}{|l|l|l|l|}
\hline Ionic medium & $\mathbf{T}\left({ }^{\circ} \mathbf{C}\right)$ & $\log \mathbf{K}_{\mathrm{s} 0}$ & Reference \\
\hline dilute & 25 & 7.8 & Oka (1938, ref. 66) \\
variable & 18 & 4.7 & Korenman (1955, ref. 66) \\
variable & - & 4.0 & Starik et al. (1957, ref. 66) \\
0 correlation & 19 & 2.7 & Kovalenko \& Bagdasarov (1961, ref. 66) \\
$1 \mathrm{M} \mathrm{NaClO}$ & 20 & 3.8 & Bilinski et al. (1966, ref. 62) \\
dilute & 20 & 4.6 & Bilinski et al. (1966, ref. 62) \\
dilute & 40 & 5.1 & Bilinski et al. (1966, ref. 62) \\
extrapolated & 25 & 1.6 & Bilinski et al. (1966, ref. 62) \\
\hline
\end{tabular}

There are two widely different values for $\Delta \mathrm{G}_{\mathrm{f}(\mathrm{H} 4 \mathrm{SiO} 4)}$ in the literature. The lower value is reported by Wagman et al. (1982), ${ }^{66} \Delta \mathrm{G}_{\mathrm{f}(\mathrm{H} 4 \mathrm{SiO} 4)}=-1316.6 \mathrm{~kJ} / \mathrm{mole}$. The higher value is reported by Paul (1982), ${ }^{68} \Delta \mathrm{G}_{\mathrm{f}(\mathrm{H} 4 \mathrm{SiO} 4)}=-1256.75 \mathrm{~kJ} / \mathrm{mole}$. The $60 \mathrm{~kJ}$ difference in these values results in a ten order of magnitude difference in the calculated $\mathrm{K}$-value for the zircon hydration reaction (9). This discrepancy is too large to be explained as experimental error. One possible explanation for the discrepancy is hydration in quartz, a phenomenon not often accounted for in the calorimetric studies of the heat of formation of quartz.

\subsection{Conclusions}

A review of the available thermodynamic data show that Tole's (1985, ref. 50) model of zircon dissolution cannot be verified. Tole concluded that in order to quantify zircon dissolution, concentrations of $\mathrm{Zr}$ and $\mathrm{Si}$ species in the order of 0.1 to $1 \mathrm{ppb}$ must be measured. This is not possible with current analytical instruments. Inconsistencies in the $\Delta \mathrm{G}_{\mathrm{f}} \mathrm{H}_{4} \mathrm{SiO}_{4}$ values make it impossible to calculate concentrations of dissolved zircon. This is the reason why we selected a dissolution test based on an open system. 


\section{Measurement of the dissolution rate of crystalline zircon}

Two Soxhlet extractors were used to dissolve a crystalline synthetic zircon powder in the temperature range 120 to $250^{\circ} \mathrm{C}$. Samples were drawn from the solvent reservoir of the Soxhlet extractor over a period of approximately 300 hours. The solutions were analyzed for Si using the molybdate blue method. Data analysis of the results yield the forward rate of zircon dissolution at the temperatures studied. The kinetic data at different temperatures were then used to calculate the activation energy for the dissolution of pure crystalline zircon.

\subsection{Sample description}

A commercial crystalline synthetic zircon powder was obtained for these experiments from Cerac, Inc., Milwaukee, WI., lot \# 96017-A-1. The manufacturer's reported spectrographic analysis is given in Table 6 . The reported $\mathrm{Zr}$ wt. \% value is 1.15 wt. \% lower than the theoretical value of $49.76 \mathrm{wt} . \%$. A complete structural and chemical analysis of the zircon was conducted to ascertain purity.

\subsubsection{Analytical techniques}

$X$-ray diffraction analysis (XRD) was completed on a Scintag diffractometer operated at $20 \mathrm{kV}$ using $\mathrm{Cu}$ radiation $(\lambda-1.5418 \AA)$. The zircon powder was suspended in acetone and evaporated onto a zero background quartz plate. Transmission electron microscopy (TEM) was conducted on a JEOL 2000FX operated at $200 \mathrm{kV}$ with a point to point resolution of $2.5 \AA$. Energy dispersive X-ray spectroscopy (EDS) was completed on a JEOL JSM-5800LV scanning electron microscope (SEM) operated at $15 \mathrm{kV}$, with a focused beam diameter of 1 micron and a counting time of $60 \mathrm{~s}$. Trace element analysis was conducted using a quadrapole type VG 5800 inductively coupled plasma mass spectrometer (ICP-MS). The zircon sample was dissolved in a lithium metaborate, $\mathrm{LiBO}_{2}$, flux at $1450^{\circ} \mathrm{C}$ and then dropped into a $5 \% \mathrm{HNO}_{3}$ solution. The solution was stirred for several hours until all particles were dissolved. Blank solutions were prepared using the $\mathrm{LiBO}_{2}$ flux. The blank concentrations were then subtracted from the sample concentrations for the trace elements analyzed.

The zircon particle size distribution was measured using a Coulter LS230 instrument, which uses the scattering of laser light by the particles to determine particle 
size. The laser light has a wavelength of $750 \mathrm{~nm}$ and can detect particles from $0.4 \mu \mathrm{m}$ to $2000 \mu \mathrm{m}$ in diameter.

Table 6. Spectrographic analysis of crystalline synthetic zircon as reported by Cerac, Inc. No value for Si was reported.

\begin{tabular}{|l|l|}
\hline element & result (wt.\%) \\
\hline $\mathrm{Zr}$ & 48.61 \\
$\mathrm{Al}$ & 0.09 \\
$\mathrm{Ca}$ & 0.02 \\
$\mathrm{Cu}$ & $<0.01$ \\
$\mathrm{Fe}$ & 0.02 \\
$\mathrm{Mg}$ & $<0.01$ \\
$\mathrm{Ti}$ & 0.05 \\
$\mathrm{~V}$ & $<0.01$ \\
\hline
\end{tabular}

\subsubsection{Results}

XRD was used to analyze for the presence of crystalline phases other than zircon such as $\mathrm{SiO}_{2}$ or $\mathrm{ZrO}_{2}$ (Figure 4). The XRD pattern matches the JCPDS reference standard zircon pattern (06-0266). No non-zircon peaks were identified. TEM was used to determine if any unreacted amorphous silica, which would not appear in the XRD pattern, was present in the sample. No amorphous $\mathrm{SiO}_{2}$ was observed. A major element chemical analysis was completed using the SEM-EDS. The results of six analyses are given in Table 7. The theoretical concentrations of $\mathrm{Zr}, \mathrm{Si}$ and $\mathrm{O}$ (in wt\%) are listed for comparison. All totals were low suggesting the presence of approximately $3 \mathrm{wt} . \%$ impurity elements. Oxygen was calculated, not directly measured.

Table 7. Major element EDS analyses. All values are reported in wt.\%. The values for the ideal zircon composition are reported in the last column for comparison.

\begin{tabular}{|l|l|l|l|l|l|l|l|}
\hline element & $\# \mathbf{1}$ & $\mathbf{\# 2}$ & $\mathbf{\# 3}$ & $\mathbf{\# 4}$ & $\mathbf{\# 5}$ & $\mathbf{\# 6}$ & theor. \\
\hline $\mathrm{Zr}$ & 47.52 & 48.66 & 48.90 & 47.11 & 47.93 & 49.26 & 49.76 \\
$\mathrm{Si}$ & 14.73 & 15.01 & 13.97 & 14.61 & 14.89 & 14.77 & 15.32 \\
$\mathrm{O}$ & 34.64 & 34.83 & 34.16 & 34.97 & 34.51 & 34.81 & 34.92 \\
total & 96.89 & 98.50 & 97.03 & 96.69 & 97.33 & 98.84 & 100 \\
\hline
\end{tabular}


Twenty impurity elements were detected and analyzed including $\mathrm{Y}, \mathrm{La}, \mathrm{Ce}, \mathrm{REE}$, $\mathrm{Ti}, \mathrm{Hf}, \mathrm{Th}, \mathrm{U}$, and $\mathrm{Fe}$ (Table 7). All trace elements detected are common constituents in zircon samples. The synthetic zircon powder had a BET surface area of $0.048 \mathrm{~m}^{2} / \mathrm{g}$ and an average grain diameter of $50 \mu \mathrm{m}$ as measured by the Coulter particle size analyzer. The zircon powder was placed in a Teflon mesh bag with a mesh size of $11 \mu \mathrm{m}$, smaller than the minimum particle size as confirmed by particle size measurement.

\subsection{Dissolution experiments}

Approximately $1 \mathrm{~g}$ of crystalline synthetic zircon powder was placed into a Teflon mesh bag. The bag was closed using Teflon tape, and placed into the sample cup of a Soxhlet extractor. Approximately $150 \mathrm{ml}$ of a $\mathrm{NaOH}$ solution with a $\mathrm{pH}=12$ was placed

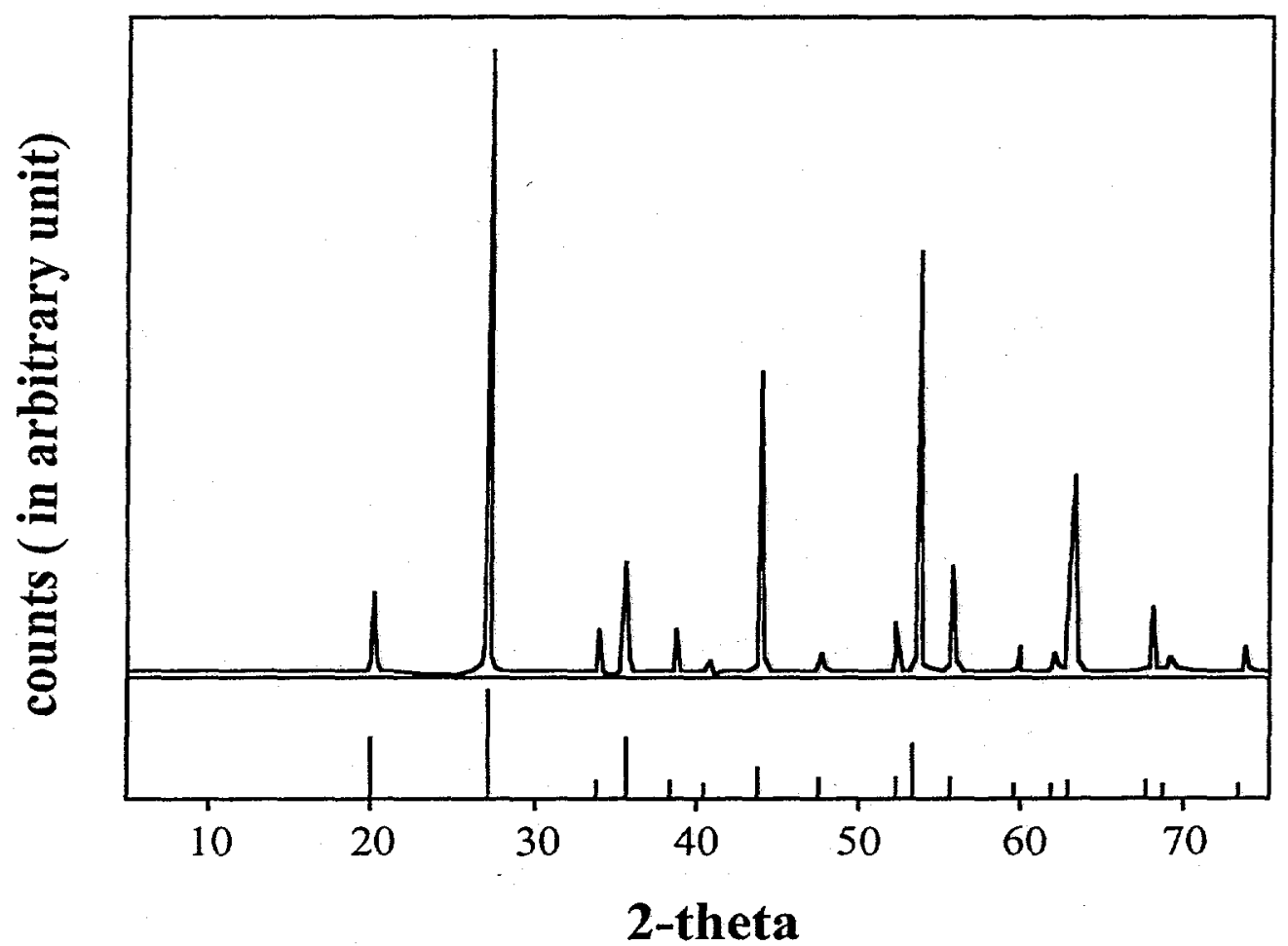

Fig. 4. XRD spectrum of synthetic zircon powder. The JCPDS standard reference pattern for zircon is shown for comparison below the measured spectrum.

into the solvent reservoir. A sodium hydroxide solution was used to prevent $\mathrm{H}_{4} \mathrm{SiO}_{4}$ from reaching saturation with respect to zircon. In this way, formation of zircon is suppressed in the leachate to be analyzed. The Soxhlet extractor was sealed by tightening 8 bolts and placed into a heating mantle set for the desired temperature. The Soxhlet was periodically removed from the heating mantle, cooled and a $2 \mathrm{ml}$ sample was drawn from the solvent 
reservoir for up to approximately 300 hours. The $\mathrm{pH}$ of the solution in the zircon sample cup was measured to detect spill-over of the $\mathrm{NaOH}$ solution in the reservoir. Some spillover was actually detected, leading to an increase of the leachant in the zircon sample cup of $8<\mathrm{pH}<10$. The samples were then analyzed for $\mathrm{Si}$ using the molybdenum-blue method. The reagents used were ammonium molybdate $\left(\left(\mathrm{NH}_{4}\right)_{6} \mathrm{Mo}_{7} \mathrm{O}_{24} \cdot 4 \mathrm{H}_{2} \mathrm{O}\right)$ dissolved in an aqueous solution of $\mathrm{H}_{2} \mathrm{SO}_{4}$; an oxalic acid $\left.(\mathrm{COOH})_{2} \cdot 2 \mathrm{H}_{2} \mathrm{O}\right)$ solution, used to suppress phosphorous interference; the reducing agent was hydroxylamine hydrochloride $\left(\mathrm{NH}_{2} \mathrm{OH} \cdot \mathrm{HCl}\right)$ / stannous chloride $\left(\mathrm{SnCl}_{2} \cdot 2 \mathrm{H}_{2} \mathrm{O}\right)$ dissolved in dilute $\mathrm{H}_{2} \mathrm{SO}_{4}$. Soluble silica species react with molybdate at approximately $25^{\circ} \mathrm{C}$ and $\mathrm{pH}=1.2$ to form a yellow silicomolybdate complex. Molybdenum is reduced in stannous chloride and a blue complex of heteropoly acid forms which has an absorbency maximum at $820 \mathrm{~nm}$. The intensity of the color is proportional to the concentration of silica. A Bausch and Lomb Spectronic 88 spectrophotometer was used to measure the transmittance at $820 \mathrm{~nm}$ for each sample and for a series of known standards. The detection limit was $5 \mathrm{ppb}$.

Table 8. Three ICP-MS analyses of the crystalline synthetic zircon (ppm).

\begin{tabular}{|l|l|l|l|l|l|l|l|}
\hline & Y-89 & La-139 & Ce-140 & Pr-141 & Nd-146 & Eu-151 & S m-152 \\
\hline$\# 1$ & 966.12 & 14.25 & 48.30 & 2.00 & 15.49 & 0.68 & 4.19 \\
$\# 2$ & 946.38 & 13.70 & 46.21 & 1.94 & 14.78 & 0.67 & 4.15 \\
$\# 3$ & 906.60 & 13.68 & 45.81 & 1.92 & 14.67 & 0.63 & 3.90 \\
\hline & Gd-158 & Tb-159 & Dy-161 & Ho-165 & Er-166 & Tm-169 & Yb-174 \\
\hline$\# 1$ & 24.03 & 4.51 & 77.95 & 30.61 & 144.05 & 29.36 & 260.09 \\
$\# 2$ & 23.31 & 4.56 & 75.76 & 29.80 & 144.49 & 29.01 & 262.07 \\
$\# 3$ & 22.49 & 4.36 & 75.77 & 29.29 & 137.94 & 27.89 & 251.17 \\
\hline & Lu-175 & Ti-48* & Hf-178 & Th-232 & U-238 & Fe-56* & \\
$\# 1$ & 43.04 & 2100 & $1.18 \%$ & 720 & 260 & 1304 & \\
$\# 2$ & 42.82 & 2098 & $1.23 \%$ & 717 & 276 & 1292 & \\
$\# 3$ & 41.95 & 2106 & $1.25 \%$ & 724 & 289 & 1314 & \\
\hline
\end{tabular}

*high background in the blank for $\mathrm{Ti}$ and $\mathrm{Fe}{ }^{*} \mathrm{Hf}$ in wt.\%). 
A volume correction of the Si concentrations was necessary due to the reduction in total solution volume by sample withdrawal. The correction applied was:

$$
\left(\mathrm{V}_{\mathrm{n}} / \mathrm{V}_{\mathrm{i}}\right) \mathrm{C}_{\mathrm{n}}=\mathrm{C}_{\mathrm{f}}
$$

where $V_{n}$ is the total solution volume just prior to collecting sample $n, V_{i}$ is the initial solution volume, $C_{n}$ is the $\mathrm{Si}$ concentration of sample $n ; C_{f}$ is the final, volume corrected Si concentration.

\subsection{Results}

Four leaching experiments were conducted at $250,200,150$ and $120^{\circ} \mathrm{C}$. A linear regression model of the respective calibration curves was created to estimate the $\mathrm{Si}$ concentrations from the percent transmittance measurements. The volume corrected $\mathrm{Si}$ concentrations were then plotted against time. The dissolution rates are proportional to the slope of the least-squares fitted lines. The rates were used to calculate the activation energy of zircon dissolution. The results of this study were compared to the results obtained by Tole $(1985)^{50}$ and Ewing et al. (1982). ${ }^{48}$

\subsubsection{Dissolution rate of zircon at $250^{\circ} \mathrm{C}$}

The first experiment was conducted in a pristine Soxhlet extractor with no visible signs of degradation of the gold plating or alteration of the stainless steel. A series of five blanks were collected over five days to measure background silica concentrations. Then the zircon sample was introduced into the Soxhlet and nine samples were collected. All 14 samples (five blanks and nine samples) were collected over a period of 367 hours. The average temperature in the Soxhlet was $(250 \pm 15)^{\circ} \mathrm{C}$ and the average $\mathrm{pH}$ in the sample cup was $9 \pm 0.9$.

Thirteen Si measurements were made and are reported in Table 9. A plot of the Si concentration in ppb against time is shown in Figure 5. The least squares line is indicated. The equation for the least-squares fitted line is:

$$
\mathrm{ppb} \mathrm{Si}=1.5425+0.8296 \times \mathrm{time}(\mathrm{hr})
$$

The Si release from the zircon sample is $0.830 \mathrm{ppb}$ Si per hour or $19.911 \mathrm{ppb} \mathrm{Si}$ per day. The dissolution rate at $250^{\circ} \mathrm{C}$ of the zircon sample as measured by the Si release profile is:

$$
(19.911 \mu \mathrm{g} / 1 \mathrm{Si})\left(10^{-6} \mathrm{~g} / \mu \mathrm{g}\right)\left(183.3 \mathrm{~g} \mathrm{ZrSiO}_{4} / 28 \mathrm{~g} \mathrm{Si}\right)(0.152 \mathrm{l}) /\left(0.04789 \mathrm{~m}^{2}\right)=
$$




$$
\left(4.1 \times 10^{-4} \pm 2.8\right) \mathrm{gm}^{-2} \mathrm{~d}^{-1}
$$

where 0.1521 is the amount of solution in the solvent reservoir at the beginning of the experiment and $0.04789 \mathrm{~m}^{2}$ is the BET surface area $\left(0.048 \mathrm{~m}^{2} / \mathrm{g}\right)$ times $0.9977 \mathrm{~g}$, the amount of zircon powder used in the experiment.

The five blanks collected over the first $100 \mathrm{hrs}$. of the experiment, before the zircon sample was placed into the Soxhlet vessel, showed a slight increase in the background concentration of Si (Table 9, observations 1-5). There is a linear increase in the Si concentration over time in the absence of zircon dissolution. The data indicates that the Soxhlet vessel yields approximately $0.20 \mathrm{ppb}$ Si per hour to the solvent. This is less than $5.0 \mathrm{ppb} \mathrm{Si}$ per day. This small contribution is ignored in the calculation of the dissolution rate for zircon, as it is not possible to distinguish this small background value from error in the measurement in any statistically meaningful manner due to the small sample size ( $\mathrm{n}=5$ for the background model). The calculated dissolution rate for zircon at $250^{\circ} \mathrm{C}$ is considered an upper limit.

Table 9. Si concentration in ppb and time in hours. The last column gives the volume corrected $\mathrm{Si}$ concentrations. The first five observations correspond to the procedural blanks. The last nine observations were used to develop a linear regression model and to calculate the dissolution rate for zircon at $250^{\circ} \mathrm{C}$.

\begin{tabular}{|l|l|l|l|}
\hline Observation & Time (hrs.) & ppb Si & corrected ppb Si \\
\hline 1 & 0 & $*-34.141$ & 0.000 \\
2 & 23.58 & 0.000 & 0.000 \\
3 & 52.53 & 3.518 & 3.430 \\
4 & 73.33 & 10.311 & 9.920 \\
5 & 100.42 & 20.458 & 19.415 \\
6 & 121.83 & 39.785 & 37.785 \\
7 & 149.17 & 39.789 & 36.765 \\
8 & 166.25 & 76.060 & 69.290 \\
9 & 197.67 & 79.598 & 71.479 \\
10 & 219.70 & 80.041 & 70.916 \\
11 & 243.50 & 85.203 & 73.275 \\
12 & 271.33 & 184.000 & 155.849 \\
13 & 367.33 & 318.100 & 253.526 \\
\hline
\end{tabular}

*this value set to zero 


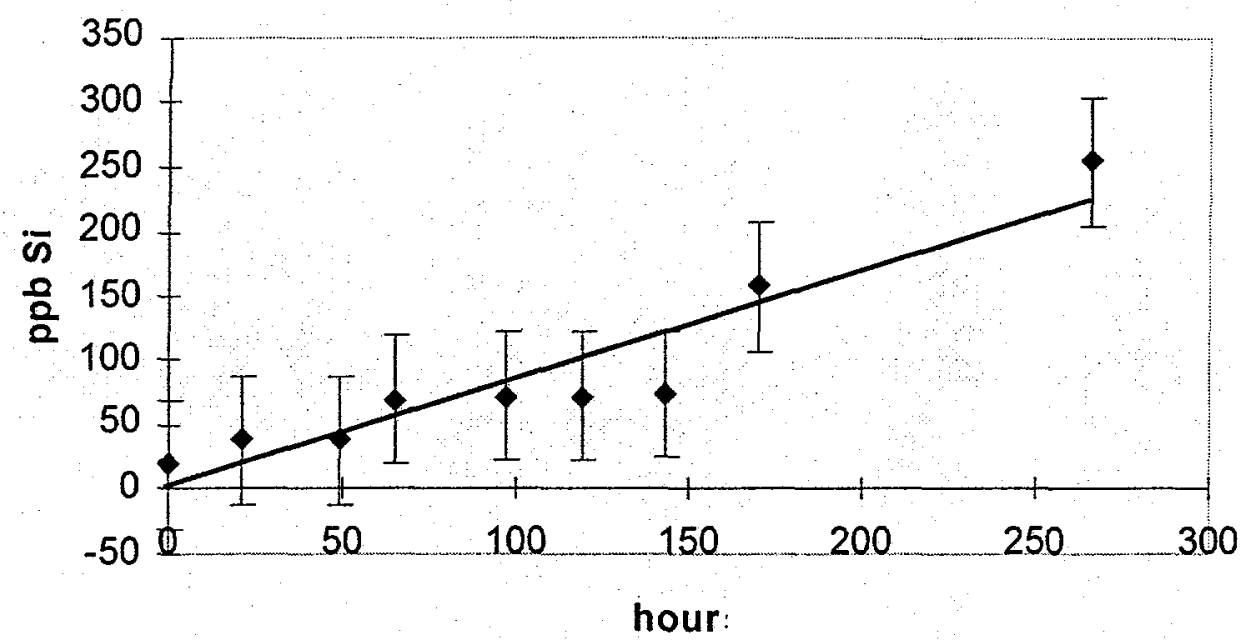

Fig. 5. Si concentration as a function of time at $250^{\circ} \mathrm{C}$. The error bars correspond to the standard error.

Table 10. Si concentration in ppb and time in hours. The last column gives the volume corrected Si concentrations. The first five observations correspond to the procedural blanks. The last seven observations were used to develop a linear regression model and to calculate the dissolution rate for zircon at $200^{\circ} \mathrm{C}$.

\begin{tabular}{|l|l|l|l|}
\hline Observation & Time (hrs.) & ppb Si & corrected ppb Si \\
\hline 1 & 0 & 20.125 & 20.125 \\
2 & 19.5 & $-2.267^{*}$ & 0.000 \\
3 & 43.2 & $-3.938^{*}$ & 0.000 \\
4 & 72.1 & 20.793 & 20.003 \\
5 & 99.0 & 9.096 & 8.638 \\
6 & 126.8 & 2.746 & 2.573 \\
7 & 149.8 & 23.467 & 21.695 \\
8 & 172.7 & 33.493 & 30.542 \\
9 & 218.4 & 26.141 & 23.508 \\
10 & 247.8 & 52.878 & 46.887 \\
11 & 269.2 & 86.299 & 75.438 \\
\hline
\end{tabular}

*this value set to zero. 


\subsubsection{Dissolution rate of zircon at $200^{\circ} \mathrm{C}$}

This experiment was the first conducted in the second Soxhlet extractor. There were no visible signs of degradation of the gold plating or alteration of the stainless steel. A series of five blanks were collected over five days to measure the background silica concentrations. Then the zircon sample was introduced into the Soxhlet, and six samples were collected. All 11 samples (five blanks and six samples) were collected over a period of 270 hours. The temperature was $(200 \pm 7)^{\circ} \mathrm{C}$, and the $\mathrm{pH}$ in the sample cup was $9.3 \pm 0.4$

The Si concentrations estimated from the linear regression model of the calibration curve were volume corrected and used to develop a model for the Si release profile over time. The data used for this model are given in Table 10. Time is reported in hours.

A plot of $\mathrm{Si}$ concentration in $\mathrm{ppb}$ for observations 5-11 against time is shown in Figure 6. The data were time corrected, i.e. time for observation 5 is set to $t=0$. The least squares fitted line is shown. The equation of the least squares fitted line is:

$$
\text { ppb Si }=-2.396+0.357 \times \text { time(hr) }
$$

The Si release from the zircon sample is $0.357 \mathrm{ppb}$ Si per hour or $8.57 \mathrm{ppb}$ Si per day. The dissolution rate at $200^{\circ} \mathrm{C}$ of the zircon sample as measured by the Si release profile is:

$(8.571 \mu \mathrm{g} / 1 \mathrm{Si})\left(10^{-6} \mathrm{~g} / \mu \mathrm{g}\right)\left(183.3 \mathrm{~g} \mathrm{ZrSiO}_{4} / 28 \mathrm{~g} \mathrm{Si}\right)(0.1534 \mathrm{l}) /\left(0.05184 \mathrm{~m}^{2}\right)$

$$
=\left(1.7 \times 10^{-4} \pm 1.9\right) \mathrm{gm}^{-2} \mathrm{~d}^{-1}
$$

where 0.1521 is the amount of solution in the solvent reservoir at the beginning of the experiment and $0.05184 \mathrm{~m}^{2}$ is the BET surface area $\left(0.048 \mathrm{~m}^{2} / \mathrm{g}\right)$ times $1.080 \mathrm{~g}$, the amount of zircon powder used in the experiment. 


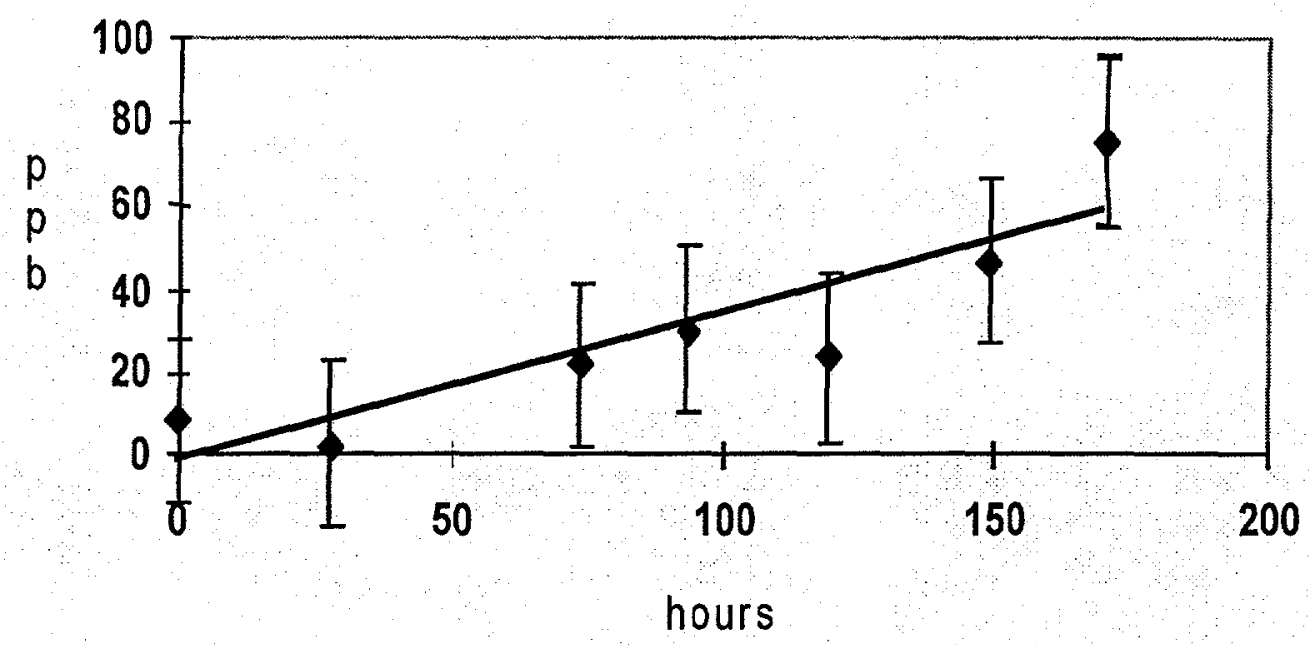

Fig. 6. Si concentration as a function of time at $200^{\circ} \mathrm{C}$. The error bars correspond to the standard error.

The five blanks collected over the first $99 \mathrm{hrs}$. of the experiment, before the zircon sample was placed into the Soxhlet vessel, showed no leaching of Si from the Soxhlet vessel used for this experiment (Table 10, observations 1-5).

\subsubsection{Dissolution rate of zircon at $120^{\circ} \mathrm{C}$}

This experiment was the second conducted in the Soxhlet extractor designated as Soxhlet A. There were visual signs of degradation of the gold coating as well as alteration on the bottom of the stainless steel sample cup. A series of three procedural blanks were collected over five days to measure the background silica concentrations. Then the zircon sample was introduced to the Soxhlet, and seven samples were collected. All ten samples (three procedural blanks and seven samples) were collected over a period of 384 hours. The average temperature in the Soxhlet was $(123 \pm 9)^{\circ} \mathrm{C}$ and the average $\mathrm{pH}$ in the sample cup was $8.8 \pm 0.5$.

The Si concentrations estimated from the linear regression model of the calibration curve were volume corrected and used to develop a model for the Si release profile over time. The data used for this model are given in Table 11. 
Table 11. Si concentration in $\mathrm{ppb}$ as a function of corrosion time at $120^{\circ} \mathrm{C}$. The first three observations correspond to the procedural blanks. The last eight observations were used to calculate the dissolution rate for zircon.

\begin{tabular}{|l|l|l|l|}
\hline Observation & Time (hours) & ppb Si & corrected ppb Si \\
\hline 1 & 0.000 & 3.174 & 3.174 \\
2 & 46.60 & 11.997 & 11.636 \\
3 & 119.85 & 3.174 & 2.935 \\
4 & 144.18 & 45.523 & 41.417 \\
5 & 193.45 & 38.465 & 33.837 \\
6 & 242.95 & 56.111 & 47.655 \\
7 & 265.45 & 47.288 & 39.445 \\
8 & 292.2 & 66.698 & 54.635 \\
9 & 338.2 & 73.756 & 58.178 \\
10 & 383.9 & 79.050 & 60.016 \\
\hline
\end{tabular}

A plot of Si concentration in $\mathrm{ppb}$ against time is shown in Figure 7. A time correction was applied to set the last blank at time, $t=0$. The least squares fitted line is shown. The equation for the least-squares fitted line is:

$$
\mathrm{ppb} \mathrm{Si}=17.315+0.165 \times \text { time }(\mathrm{hr})
$$

The Si release from the zircon sample is $0.165 \mathrm{ppb}$ Si per hour or $3.952 \mathrm{ppb}$ Si per day. The dissolution rate at $120^{\circ} \mathrm{C}$ of zircon as measured by the $\mathrm{Si}$ release profile is:

$$
\begin{gathered}
(3.952 \mu \mathrm{g} / 1 \mathrm{Si})\left(10^{-6} \mathrm{~g} / \mu \mathrm{g}\right)\left(183.3 \mathrm{~g} \mathrm{ZrSiO}_{4} / 28 \mathrm{~g} \mathrm{Si}\right)(0.1292 \mathrm{l}) /\left(0.04767 \mathrm{~m}^{2}\right)= \\
\left(7.1 \times 10^{-5} \pm 0.9\right) \mathrm{gm}^{-2} \mathrm{~d}^{-1}
\end{gathered}
$$




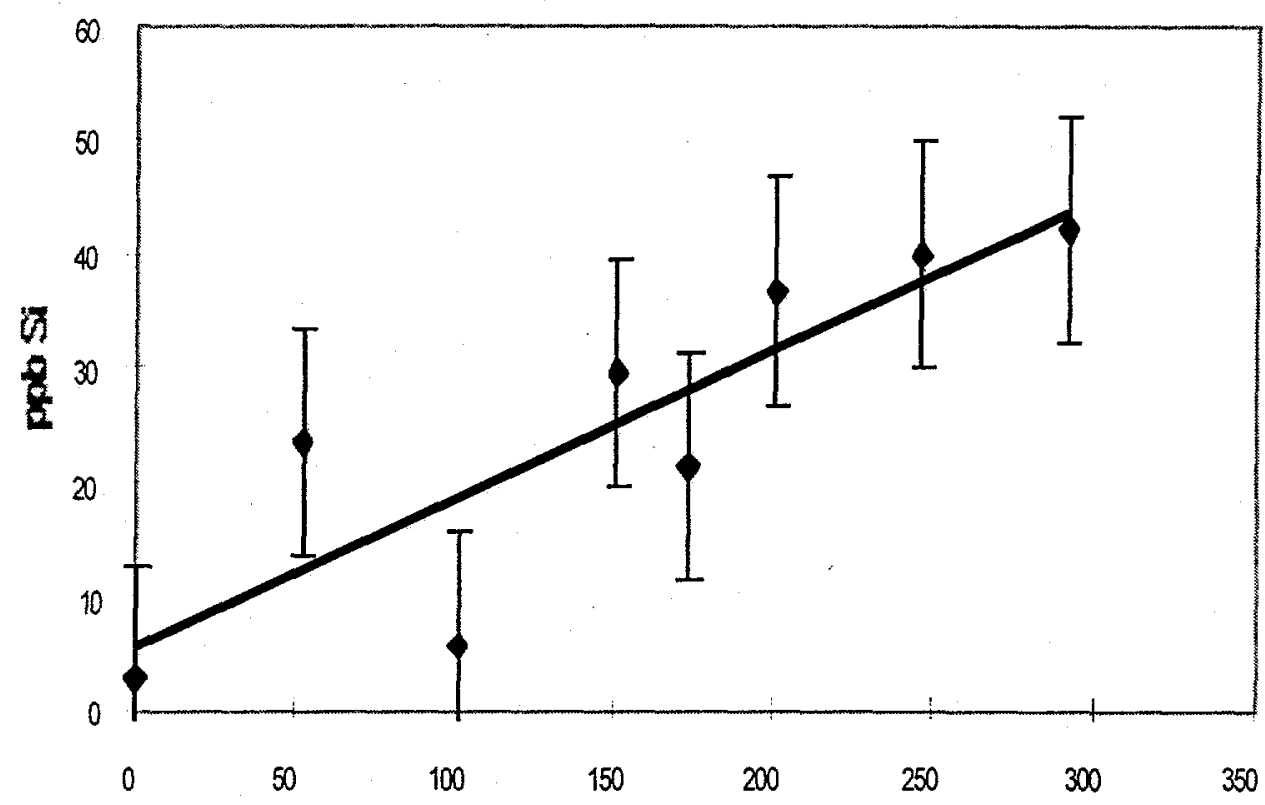

Fig. 7. Si concentration as a function of time for zircon dissolution at $120^{\circ} \mathrm{C}$. The error bars correspond to the standard error.

where 0.12921 is the amount of solution in the solvent reservoir at the beginning of the experiment and $0.04767 \mathrm{~m}^{2}$ is the BET surface area $0.048 \mathrm{~m}^{2} / \mathrm{g}$ times $0.9931 \mathrm{~g}$, the amount of zircon powder used in the experiment.

The three procedural blanks collected over the first $120 \mathrm{hrs}$. of the experiment, before the zircon sample was placed into the Soxhlet vessel, showed no systematic leaching of Si from the vessel used for this experiment (Table 11, observations 1-3).

\subsubsection{Activation energy of zircon dissolution}

The rate of zircon dissolution was measured at three temperatures, 250, 200 and $120^{\circ} \mathrm{C}$. These three rates were used to calculate the activation energy of zircon dissolution from the Arrhenius equation:

$$
k(T)=A e^{-E / R T}
$$


where $k(T)$ is the measured rate at temperature, $T$ in Kelvin, $A$ is the pre-exponential factor, $\mathrm{E}_{\mathrm{a}}$ is the activation energy in $\mathrm{J}$, and $\mathrm{R}$ is the molar gas constant, $8.3145 \mathrm{Jmole}^{-1} \mathrm{~K}$. The data used in the calculation are summarized in Table 12.

Table 12. The measured rates of zircon dissolution at three temperatures (in K).

\begin{tabular}{|l|l|l|l|}
\hline $\mathbf{k}\left(\mathbf{m o l e} / \mathbf{m}^{-2} \mathbf{d}^{-1}\right)$ & $\ln (\mathbf{k})$ & $\mathbf{T}(\mathbf{K})$ & $\mathbf{1} / \mathbf{T}(\mathbf{K})$ \\
\hline $2.3 \times 10^{-6}$ & -13.0015 & 523.15 & 0.00191 \\
$9.1 \times 10^{-7}$ & -13.9142 & 473.15 & 0.00211 \\
$3.9 \times 10^{-7}$ & -14.7648 & 393.15 & 0.00254 \\
\hline
\end{tabular}

The data at 523.15 and $393.15 \mathrm{~K}$ were used to calculate the $\mathrm{E}_{\mathrm{a}}$ from the following equation:

$$
E_{\mathrm{a}}=\left[\left(\mathrm{T}_{1} \mathrm{~T}_{2}\right) /\left(\mathrm{T}_{2}-\mathrm{T}_{1}\right)\right] R \ln \left(\mathrm{k}_{\mathrm{T2}} / \mathrm{k}_{\mathrm{T1}}\right)
$$

where $T_{2}=523.15 \mathrm{~K}$ and $\mathrm{T}_{1}=393.15 \mathrm{~K}$. The calculated $\mathrm{E}_{\mathrm{a}}$ is $23196.370 \mathrm{~J}$ or $23.2 \mathrm{~kJ}$. Alternatively, $E_{a}$ can be calculated from a plot of $\ln (k)$ against $1 / T$ (Fig. 8). The slope is equivalent to $-E_{a} / R$ and the intercept is A. SAS was not used to model a linear regression for these data because of the small sample size, $n=3$.

\subsubsection{Summary of results}

The dissolution rates of synthetic crystalline zircon at three temperatures, 250, 200 and $120^{\circ} \mathrm{C}$, were measured. The dissolution rates were then used to calculate the activation energy for the dissolution of zircon at near neutral $\mathrm{pH}$. The results are reported in Table 13. 


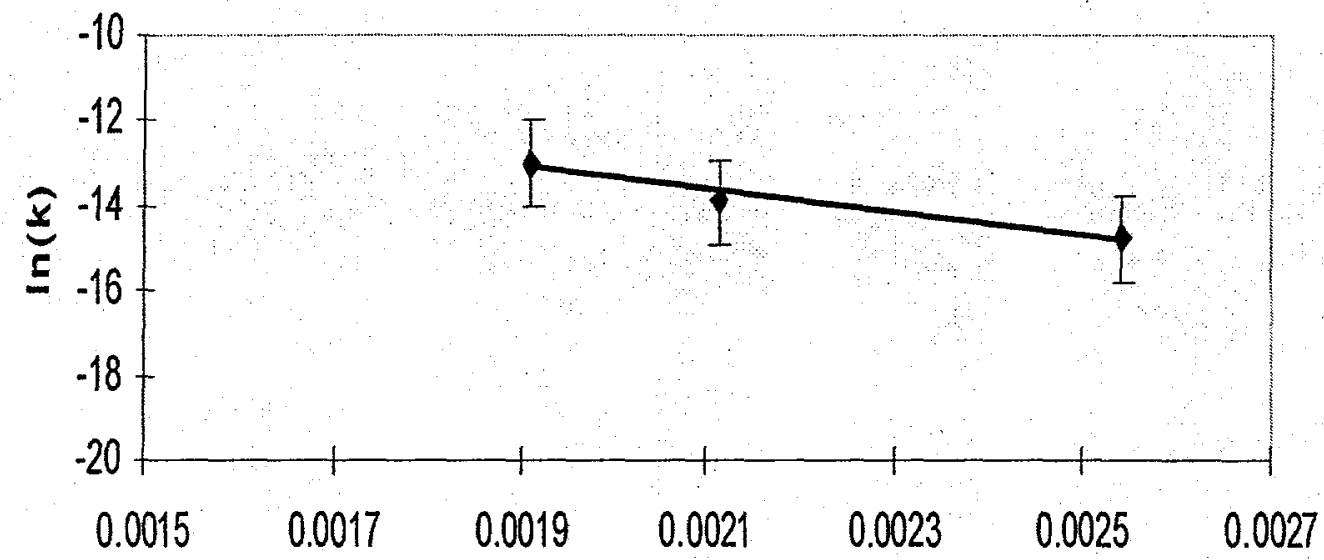

Fig. 8. A plot of $\ln (k)$ against $1 / T($ Kelvin).

Table 13. The dissolution rates for crystalline zircon at 250,200 and $120^{\circ} \mathrm{C}$. The activation energy was calculated from the Arrhenius equation, $k(T)=A e^{-E a r T T}$.

\begin{tabular}{|l|l|l|}
\hline Temperature $\left({ }^{\circ} \mathrm{C}\right)$ & $\mathbf{k}\left(\mathrm{gm}^{-2} \mathbf{d}^{-1}\right)$ & $\mathbf{E}_{\mathrm{a}}(\mathrm{kJ} / \mathrm{mole})$ \\
\hline 250 & $4.1 \times 10^{-4} \pm 0.1$ & \\
200 & $1.7 \times 10^{-4} \pm 0.1$ & 23.2 \\
120 & $7.1 \times 10^{-5} \pm 0.04$ & \\
\hline
\end{tabular}

\subsection{Discussion}

The forward rates for zircon dissolution measured in this study are not consistent with the dissolution rates published by Tole (1985, ref. 50). Tole reported a rate of $5 \times 10^{-6}$ $\mathrm{gm}^{-2} \mathrm{~d}^{-1}$ for the dissolution of metamict zircon at $80^{\circ} \mathrm{C}$. Extrapolating from the data collected in this study to $80^{\circ} \mathrm{C}$, yields a rate of $3.4 \times 10^{-5} \mathrm{gm}^{-2} \mathrm{~d}^{-1}$. Two possible explanations for the discrepancies between these two studies are: 1) Tole's reported surface area for his metamict zircon sample is too large, nearly $15 \mathrm{~m}^{2}$ per gram with a mean grain diameter of $150 \mu \mathrm{m}$. 2) Tole used data collected over 200 hours for calculating 
the forward rate of zircon dissolution in his static tests. Saturation effects may have influenced his rate.

The extrapolated value for the dissolution rate of zircon at $90^{\circ} \mathrm{C}$ from this study is $4.6 \times 10^{-5} \mathrm{gm}^{-2} \mathrm{~d}^{-1}$. Ewing et al.(1982) reported a value of $9.2 \times 10^{-4} \mathrm{gm}^{-2} \mathrm{~d}^{-1}$. The results of this study are not directly comparable to the results of Ewing et al. Their rate is higher, probably because they used a $5 \mathrm{wt} . \% \mathrm{KHCO}_{3}$ solution for their static leach test. Also, their sample surface area was not measured by BET but was only calculated.

The Arrhenius activation energy for the zircon hydration reaction, $23 \mathrm{~kJ} / \mathrm{mole}$, is consistent with the reported activation energies for zirconolite, $\mathrm{CaZrTi}_{2} \mathrm{O}_{7}$, another proposed Pu-host phase ${ }^{10}$. At $\mathrm{pH}=9$, zirconolite has an Arrhenius activation energy in the range 19-25 kJ/mole (Ringwood et al., 1988). ${ }^{69}$ However, the dissolution rate for zirconolite at $90^{\circ} \mathrm{C}$ is $5 \times 10^{-2} \mathrm{gm}^{-2} \mathrm{~d}^{-1}$ under static flow conditions. This rate is three orders of magnitude larger than the dissolution rate for zircon.

\section{Modification of the Soxhlet extractor}

Results of a leach test at $150^{\circ} \mathrm{C}$, not reported here, revealed that a significant breach of the gold coating occurred in the base of the Soxhlet extractors. This was verified by visual inspection. The effect of a defect gold coating on Si release from the vessel was studied experimentally. The extractors were thoroughly cleaned with a $\mathrm{NaOH}$ solution without zircon for a period of 3 days at temperatures in excess of $200^{\circ} \mathrm{C}$. It was then rinsed with deionized water. $\mathrm{NaOH}$ solution was then measured and placed into the solvent reservoir and the extractor was run at temperatures of $200^{\circ}$ and $150^{\circ} \mathrm{C}$. Samples were drawn over a period of 10 days, and their $\mathrm{Si}$ concentrations were measured. Background levels for both extractors were too high to render these extractors useful for additional experiments. The background Si levels in excess of $500 \mathrm{ppb}$ is taken as evidence that significant $\mathrm{Si}$ is leached from the stainless steel due to degradation of the gold coating.

Changes to the extractor design are proposed to avoid this problem in future Soxhlet experiments. The modified design is shown in Figure 9. The flange that previously sat to the interior of the solvent reservoir, now sits to the outside. This simple adjustment will allow a removable Teflon liner to be inserted into the solvent reservoir for experiments $<250^{\circ} \mathrm{C}$. For experiments $>250^{\circ} \mathrm{C}$, the Teflon liner can be removed and the solvent reservoir can be coated with gold, just as with the first design. The presence of 
the Teflon liner should keep the background concentrations of Si low and acceptable. This is particularly important in the low temperature tests for which Si concentrations are expected to be $<150 \mathrm{ppb}$.

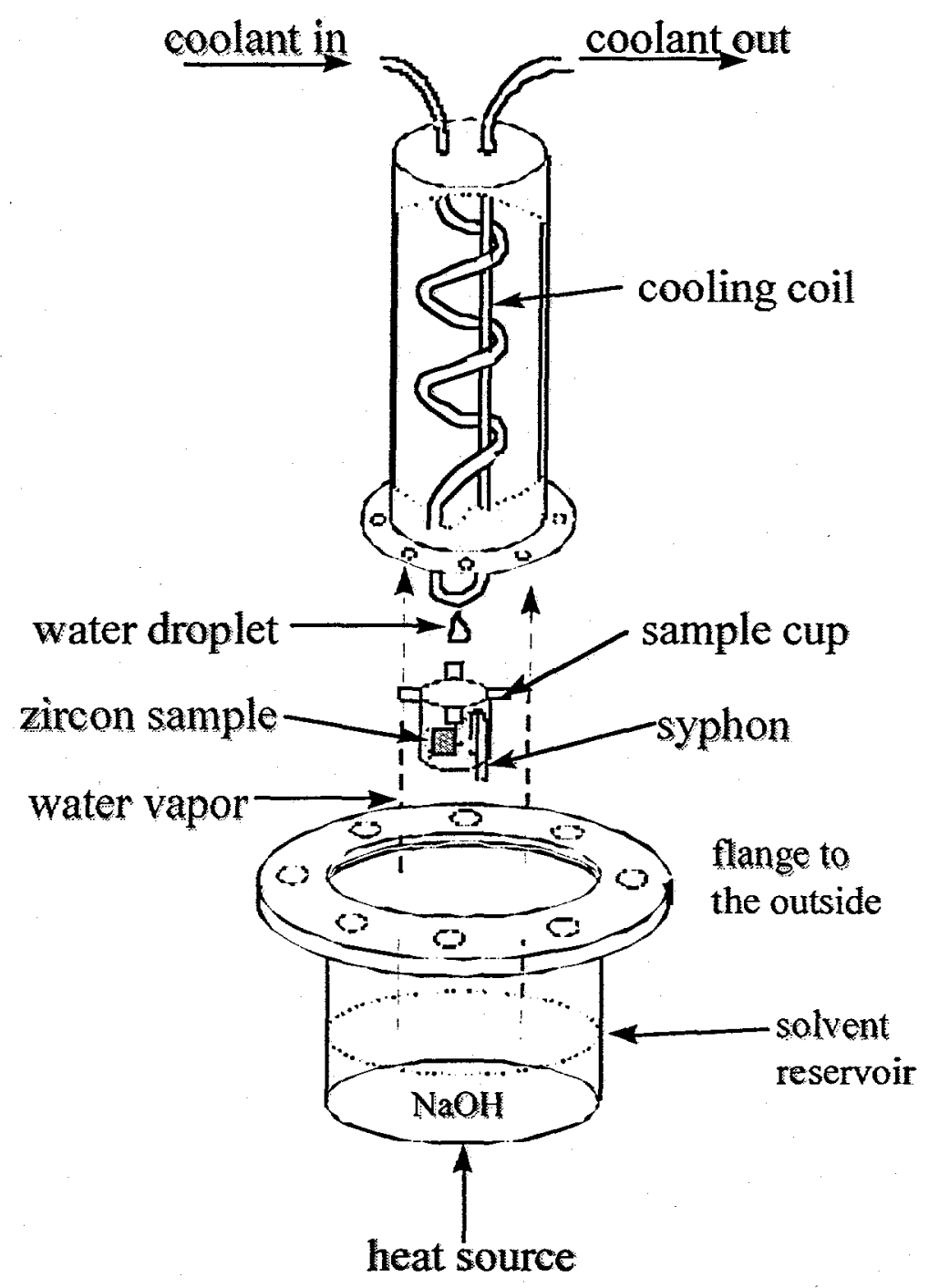

Fig. 9. The modified high temperature Soxhlet extractor.

\section{Measurement of the dissolution rate of amorphous, hydrous zircon}

One of the consequences of incorporating $\mathrm{Pu}$ into zircon is the loss of crystallinity due to the accumulation of $\alpha$-decay event damage of the structure over time. It is estimated that a complete transition to the a periodic state, the metamict state, will occur in zircon 
loaded with $10 \mathrm{wt} . \%{ }^{239} \mathrm{Pu}$ in 2,000 years (Weber, 1991). ${ }^{70}$ Once metamictization has occurred, zircon is 17 percent less dense and more readily hydrated. A hydrous, amorphous zircon represents the worst conceivable alteration for the zircon waste form. A unique aspect of developing zircon as a waste form is that natural analogues exist for all stages of the microstructural development as a function of $\alpha$-decay dose. Crystalline, metamict and hydrated amorphous zircon, or "gel-zircon", are found in nature.

A static dissolution test was conducted with natural hydrous "gel-zircon" to measure its dissolution rate. This rate is then used to estimate an upper value for the dissolution rate of metamict zircon.

\subsection{Sample description}

"Gel-zircon" is similar to natural metamict zircon, which is amorphous due to a self-irradiation caused by $\alpha$-decay events. The similarity is in the nanocrystallinity of the microstructures. The nanocrystallites found in "gel-zircon" are randomly oriented. In metamict zircon the nanocrystallites are typically oriented along crystallographic directions of the initial zircon crystal. There is no geological or mineralogical evidence that the "gelzircon" was ever crystalline. "Gel-zircon" formed as a result of metasomatic processes at low temperature $\left(\sim 300^{\circ} \mathrm{C}\right)$ precipitating initially as a gel. "Gel-zircon" has survived in an open geochemical system, the Manibay uranium mine, Kazakhstan, for more than 400 million years (Helean et al., 1997). ${ }^{71}$

Natural "gel-zircon" with an average $U$ content of $10 \mathrm{wt} \%$ was used to approximate the chemical durability of hydrated, amorphous zircon. A complete characterization of "gel-zircon" is given by Helean et al., 1997 (ref. 71). Because the natural "gel-zircon" contains numerous impurities including $\mathrm{Si}$, only the release of $\mathrm{U}$ was measured in the static dissolution tests.

\subsection{Analytical techniques}

A qualitative comparison of the "gel-zircon" before and after sintering was done using powder X-ray diffractometry on a Scintag diffractometer operated at $20 \mathrm{kV}$ using $\mathrm{Cu}$ radiation $(\lambda=0.15418 \mathrm{~nm})$. Samples were prepared as smear mounts on zero background quartz plates. 
Microtextural characterization was completed using high resolution transmission electron microscopy (HRTEM) with a JEOL 2010FX transmission electron microscope operated at $200 \mathrm{kV}$. TEM samples were prepared as crushed grains on holey carbon films supported by copper grids.

Electron microprobe mounts of "gel-zircon" were prepared to determine its composition. Quantitative energy dispersive X-ray spectroscopy (EDS) analyses were completed on a fully automated JEOL JXA-733 electron microprobe operated at $15 \mathrm{kV}$, a focused beam diameter of 1 micron and a counting time of $60 \mathrm{~s}$. Elements were analyzed against the following standards: uraninite $(\mathrm{U})$, zirconolite $(\mathrm{Zr})$, albite $(\mathrm{Na}, \mathrm{Al})$, diopside $(\mathrm{Mg}, \mathrm{Si}, \mathrm{Ca})$, rutile $(\mathrm{Ti})$, apatite $(\mathrm{P})$, galena $(\mathrm{S})$, orthoclase $(\mathrm{K})$, chromite $(\mathrm{Fe})$. Back scattered electron imaging was used to examine the textural features and element partitioning in the "gel-zircon" sample.

\subsection{Results}

X-ray diffraction patterns of "gel-zircon" before and after sintering are shown in Figure 10. The relative intensity scales of these two spectra are the same. The broad peaks of low intensity correspond to those of crystalline zircon. The spectrum is typical of nanocrystalline material (Figure 10 (a)). Upon sintering for one hour at $1400^{\circ} \mathrm{C}$, crystalline zircon formed (Figure 10 (b)).

High resolution transmission electron microscopy (HRTEM) was used to examine the microstructure of "gel-zircon". HRTEM analysis confirmed the presence of nanocrystallites in an amorphous matrix (Fig. 11). The nanocrystallites are approximately 5 to $10 \mathrm{~nm}$ in size and are too small to be analyzed using the TEM-EDS system. Lattice fringes are randomly oriented in the amorphous matrix.

Electron microprobe (EMPA) analyses are given in Table 14. Many impurity elements were found. A significant uranium content $(\approx 10 \mathrm{wt} . \%)$ was measured in the "gel-zircon" phase. Uranium was not found to associate with the impurity phases in the "gel-zircon". All EMPA totals were low. This was interpreted to indicate the presence of water in the "gel-zircon" phase. 

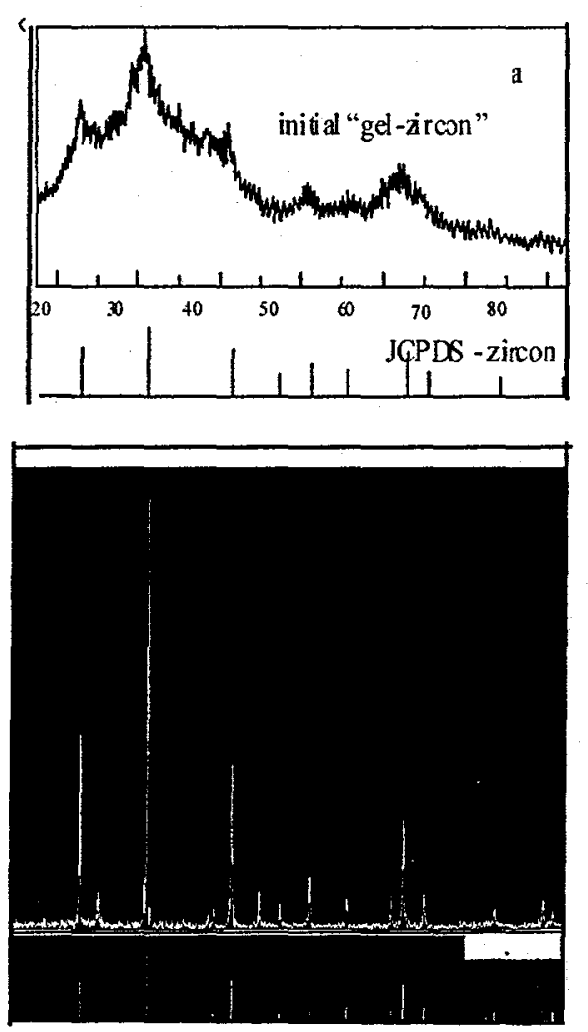

Fig. 10. X-ray diffraction patterns for "gel-zircon" before (a) and after (b) sintering at $1400^{\circ} \mathrm{C}$ for 1 hour indicating the formation of crystalline zircon. The zircon reference pattern is given for comparison.

\subsection{The static dissolution test of hydrous zircon}

A monolith of natural hydrous zircon ("gel-zircon") with an estimated surface area of $2 \mathrm{~cm}^{2}$ was leached in a polyethylene container with $50 \mathrm{ml}$ of water. The temperature of the test was $90^{\circ} \mathrm{C}$, and the test duration was 100 hours. A Scintrex UA-3 Uranium Analyzer with a detection limit of $0.05 \mu \mathrm{g} / \mathrm{L}$ with a precision of \pm 15 percent at $1 \mu \mathrm{g} / \mathrm{L}$ and above was used to measure the $U$ concentration in the leachant. 


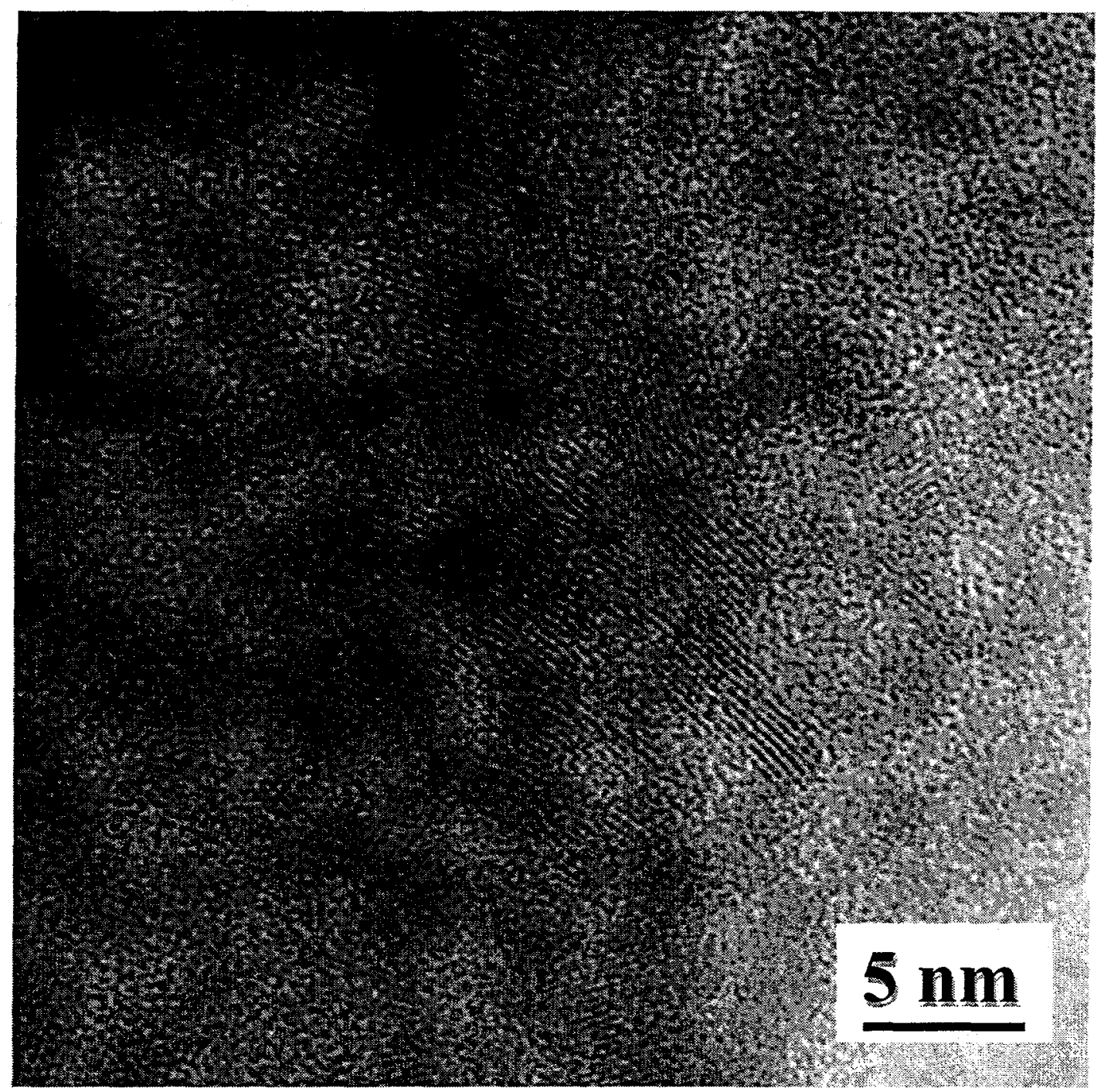

Fig. 11. HRTEM micrograph of "gel-zircon" showing the randomly oriented nanocrystallites in an amorphous matrix 
Table 14. Quantitative EDS analyses of "gel-zircon" in wt.\%. The standard error is given in parentheses.

\begin{tabular}{|c|c|c|c|c|c|}
\hline & gelzr 1 & gelzr 2 & gelzr 3 & gelzr 4 & gelzr 5 \\
\hline $\mathrm{K}_{2} \mathrm{O}$ & 0.28 & 0.29 & 0.33 & $<$ D.L. & 0.38 \\
\hline $\mathrm{CaO}$ & 2.03) & 2.12 & 2.83 & 1.86 & 2.46 \\
\hline $\mathrm{Na}_{2} \mathrm{O}$ & 11.17 & 1.33 & 4.84 & 3.58 & 4.69 \\
\hline $\mathrm{UO}_{2}$ & 6.17) & 5.76 & 4.05 & 7.59 & 9.14 \\
\hline $\mathrm{ZrO}_{2}$ & 28.83 & 32.51 & 40.27 & 41.11 & 32.11 \\
\hline $\mathrm{FeO}_{2}$ & 5.18 & 6.37 & 2.83 & 1.33 & 4.28 \\
\hline $\mathrm{MgO}$ & 1.54 & 2.83 & 0.99 & 0.54 & 1.63 \\
\hline $\mathrm{TiO}_{2}$ & 0.92 & 0.97 & 0.81 & 0.97 & 0.88 \\
\hline $\mathrm{Al}_{2} \mathrm{O}_{3}$ & 5.47 & 7.19 & 4.60 & 2.05 & 6.20 \\
\hline $\mathrm{SiO}_{2}$ & 24.12 & 27.40 & 25.50 & 22.28 & 27.83 \\
\hline $\mathrm{P}_{2} \mathrm{O}_{5}$ & $<$ D.L. & 1.11 & 0.81 & $<$ D.L. & $<$ D.L. \\
\hline $\mathrm{SO}_{3}$ & 1.11 & 1.49 & 1.26 & 1.50 & 1.87 \\
\hline \multirow[t]{2}{*}{ Total } & 86.80 & 89.36 & 89.11 & 82.81 & 91.45 \\
\hline & gelzr 6 & gelzr 7 & gelzr 8 & gelzr 9 & gelzr 10 \\
\hline $\mathrm{K}_{2} \mathrm{O}$ & 0.23 & 0.52 & $<$ D.L. & D.L. & 1.36 \\
\hline $\mathrm{CaO}$ & 2.08 & 2.30 & 3.31 & 2.26 & 2.09 \\
\hline $\mathrm{Na}_{2} \mathrm{O}$ & 5.48 & 1.10 & 0.99 & D.L. & D.L. \\
\hline $\mathrm{UO}_{2}$ & 4.27 & 6.98 & 5.10 & 3.86 & 7.17 \\
\hline $\mathrm{ZrO}_{2}$ & 25.70 & 35.97 & 41.97 & 48.30 & 25.49 \\
\hline $\mathrm{FeO}_{2}$ & 9.18 & 3.32 & 3.05 & 2.61 & 6.27 \\
\hline $\mathrm{MgO}$ & 4.19 & 1.52 & 1.35 & 0.49 & 2.61 \\
\hline $\mathrm{TiO}_{2}$ & 0.96 & 0.89 & 0.81 & 1.10 & 0.33 \\
\hline $\mathrm{Al}_{2} \mathrm{O}_{3}$ & 10.34 & 6.54 & 3.33 & 2.33 & 9.94 \\
\hline $\mathrm{SiO}_{2}$ & 28.39 & 28.93 & 23.43 & 24.66 & 28.10 \\
\hline $\mathrm{P}_{2} \mathrm{O}_{5}$ & $<$ D.L. & D.L. & 1.01 & $<$ D.L. & 0.96 \\
\hline $\mathrm{SO}_{3}$ & 0.83 & 0.77 & 4.13 & $<$ D.L. & 0.80 \\
\hline Total & 91.65 & 88.83 & 88.46 & 85.60 & 85.98 \\
\hline
\end{tabular}

*D.L. - the detection limit 
The U-release from "gel-zircon" was plotted against time (Figure 12). The initial release rate is linear. Saturation is observed after approximately 40 hours. A linear regression was used to fit a least-squares line to the linear portion of the curve. The slope of that line is proportional to the dissolution rate of "gel-zircon". The equation for the least-squares fitted line is:

$$
\text { ppb } U=0.022+0.143 \times \text { time(hr) }
$$

The U-release is $3.43 \mathrm{ppb}$ per day. The dissolution rate at $90^{\circ} \mathrm{C}$ for "gel-zircon' is:

$$
\begin{gathered}
(3.43 \mu \mathrm{g} / 1 \mathrm{U})\left(10^{-6} \mathrm{~g} / \mu \mathrm{g}\right)(10 \mathrm{~g} \text { "gel-zircon" } / 1 \mathrm{~g} \mathrm{U})(0.05 \mathrm{l}) \div\left(2 \times 10^{-4} \mathrm{~m}^{2}\right)= \\
\left(8.6 \times 10^{-3}\right) \mathrm{gm}^{-2} \mathrm{~d}^{-1}
\end{gathered}
$$

where 0.051 is the amount of solution used in this experiment and $2 \times 10^{-4} \mathrm{~m}^{2}$ is the surface area of the "gel-zircon" sample.

The dissolution rate of hydrous, amorphous zircon was measured at $8.5 \times 10^{-3} \mathrm{gm}^{-2}$ $\mathrm{d}^{-1}$ at $90^{\circ} \mathrm{C}$ in water. This is two orders of magnitude larger than the rate measured for crystalline zircon, $4.6 \times 10^{-5} \mathrm{gm}^{-2} \mathrm{~d}^{-1}$. This result is consistent with Ewing et al. $(1982)^{48}$ who observed in a different solution composition a similar increase in dissolution rates between crystalline zircon and metamict zircon. Because "gel-zircon" and metamict zircon do not have identical compositions or microstructures, further dissolution studies of metamict zircon in water must be conducted to ascertain the validity of the two order of magnitude increase in the dissolution rate.

\subsection{Conclusions}

The dissolution rate of crystalline zircon and an amorphous, hydrous zircon were measured at $90^{\circ} \mathrm{C}$ in water. The following general conclusions can be drawn from this study:

1) The high-temperature Soxhlet extractor is a suitable device to measure the dissolution rates of extremely durable materials, in this case zircon.

2) A Soxhlet with a Teflon liner to hold the leachant/leachate will better control the background concentrations of dissolved species. 
3) The forward rate of the zircon dissolution was measured for the first time and indicates that it would take more than 150,000 years to dissolve a $100 \mu \mathrm{m}$ crystal in flowing pure water at room temperature.

4) Zircon dissolution is a thermally activated process that can be described by the Arrhenius equation. The Arrhenius activation energy for zircon dissolution is 23 $\mathrm{kJ} /$ mole, indicating a relatively weak dependence of the dissolution rate on temperature . At $250^{\circ} \mathrm{C}$, the dissolution rate is on the order of $10^{-4} \mathrm{~g} / \mathrm{m}^{2} / \mathrm{d}$.
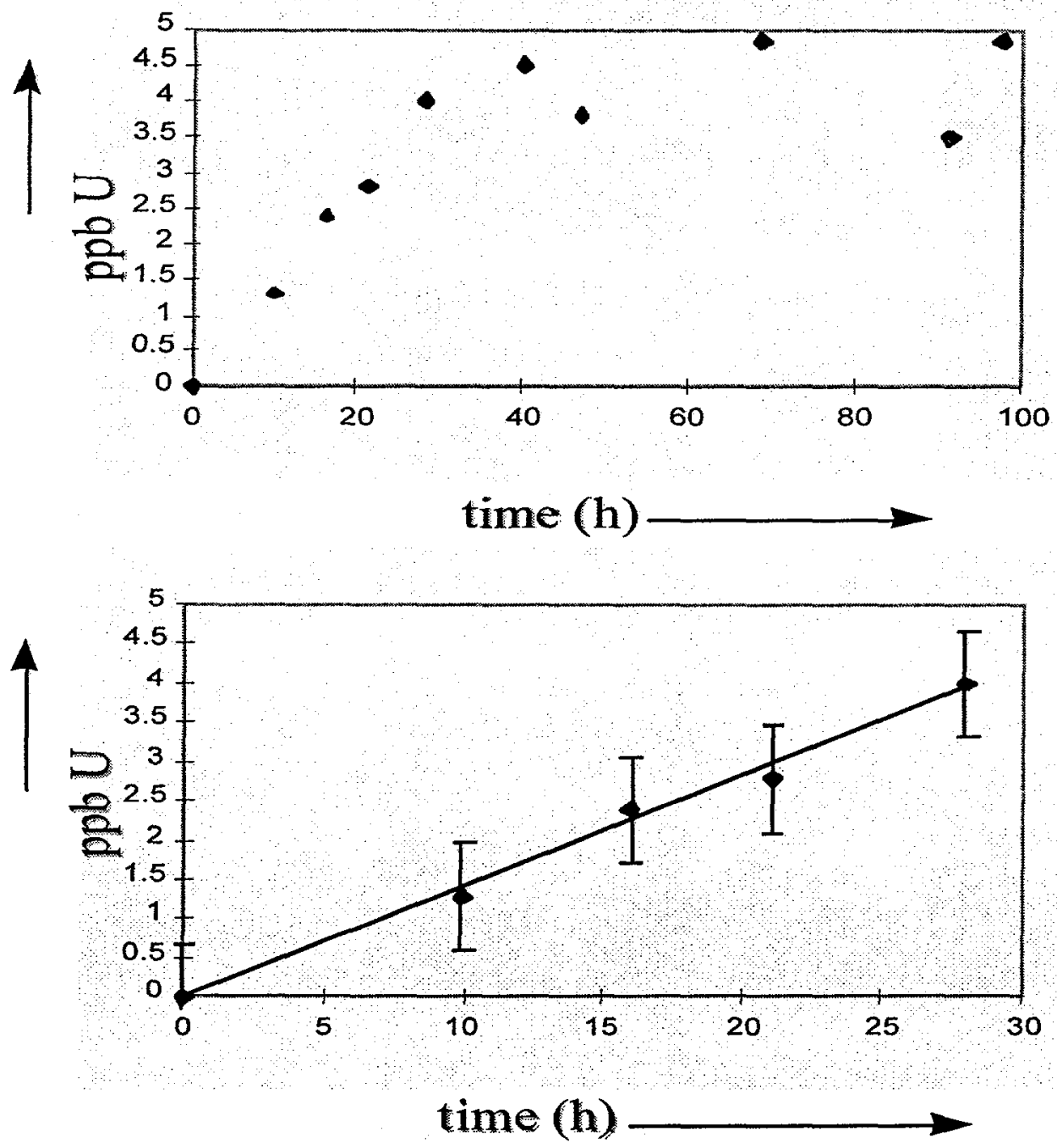

Fig. 12. U-release from "gel-zircon" in a static dissolution test at $90^{\circ} \mathrm{C}$. A leastsquaresline was fitted to the linear portion of the curve (bottom). 


\section{Synthesis of zircon solid solutions with actinides}

Zircon exhibits many attractive properties, besides that of a potential host for $\mathrm{Pu}$. Zircon has a low thermal expansion coefficient $\left(\sim 4.1 \times 10^{-6} /{ }^{\circ} \mathrm{C}\right.$ between $25^{\circ} \mathrm{C}$ and $\left.1400^{\circ} \mathrm{C}\right)$, low thermal conductivity $\left(5.1 \mathrm{~W} / \mathrm{m}{ }^{\circ} \mathrm{C}\right.$ at $\left.25^{\circ} \mathrm{C}\right)$, high chemical durability, excellent thermal shock resistance, and good high-temperature mechanical strength. ${ }^{12,13}$ Zircon sintered ceramics are used as refractories and as structural materials in high temperature environments.

Zircon can be synthesized through different methods, e.g., hydrothemal synthesis ${ }^{72}$ and the sol-gel method. ${ }^{56,73-78}$ Heterogeneously shaped $\mathrm{ZrO}_{2} \cdot \mathrm{SiO}_{2}$ particles and agglomerated solids were produced from either $\mathrm{ZrO}_{2}$ and colloidal $\mathrm{SiO}_{2}$ sols or from the hydrolysis of liquid metallo-organic precursors such tetraethylortho-silicate (TEOS) and zirconium n-propoxide or oxychloride mixtures. Spray pyrolysis techniques have been used to produce ultrafine, spherical $\mathrm{ZrO}_{2} \cdot \mathrm{SiO}_{2}$ particles. ${ }^{79-81} \quad \mathrm{ZrO}_{2} \cdot \mathrm{SiO}_{2}$ particles derived from the sol-gel method were sintered to synthesize zircon powders or compact ceramics at temperatures between 1000 and $1600{ }^{\circ} \mathrm{C}$. However, little is known about the effect of impurities on the solid-state synthesis of zircon, because the objectives of the previous work on zircon synthesis was to produce high-purity zircon powders.

Incorporation of plutonium into the zircon structure requires a reliable data base on solubility limits not only for plutonium, but also for its daughter uranium and on the optimum conditions for their synthesis. The end members, $\mathrm{USiO}_{4}, \mathrm{ThSiO}_{4}$ (Mumpton and Roy 1961), ${ }^{82} \mathrm{PuSiO}_{4}, \mathrm{AmSiO}_{4}$, and $\mathrm{NpSiO}_{4}$ (Keller, 1963) ${ }^{83}$ were synthesized with the zircon structure. However, only approximate phase diagrams are known for the $\mathrm{ZrO}_{2}$ $\mathrm{SiO}_{2}-\mathrm{UO}_{2}$ and $\mathrm{ZrO}_{2}-\mathrm{SiO}_{2}-\mathrm{ThO}_{2}$ systems.

In the experiments presented in this chapter, uranium and thorium were used to simulate plutonium. In addition, $\mathrm{Ce}$ was used as a $\mathrm{Pu}$ simulant . For $\mathrm{Pu}^{4+}$ and $\mathrm{Ce}^{4+}$, the ionic radii and the melting points of the oxides are almost identical, indicating their crystal chemical behaviors should be similar. The $\mathrm{Ce}^{4+}$ differs from $\mathrm{Pu}^{4+}$ in that the $\mathrm{Ce}^{4+}$ is easier to reduce to $\mathrm{Ce}^{3+}$ than $\mathrm{Pu}^{4+}$ is to $\mathrm{Pu}^{3+}$.

The results of X-ray diffraction and electron microscopy examinations of gel powders before and after sintering were provided in the previous report to Los Alamos National Laboratory (ref. 12). The structures of $\mathrm{ZrSiO}_{4}$ and $\left(\mathrm{Zr}_{0.9} \mathrm{Ce}_{0.1}\right) \mathrm{SiO}_{4}$ gels after calcination were revealed by TEM and XRD. The powders were mainly amorphous with 
tetragonal $\mathrm{ZrO}_{2}$ or $(\mathrm{Zr}, \mathrm{Ce}) \mathrm{O}_{2}$ nanocrystallites (some tens of nanometers in size) embedded after calcination at $800^{\circ} \mathrm{C}$. The particle of $(\mathrm{Zr}, \mathrm{Ce}) \mathrm{O}_{2}$ crystallites grew with increasing temperatures. The formation of Ce-doped zircon was presumed to be the results of the interfacial reaction of $(\mathrm{Zr}, \mathrm{Ce}) \mathrm{O}_{2}$.

We pursued two goals:

1. to develop zircon ceramics using the sol-gel method and,

2. to obtain a database on the solubilities of $\mathrm{Ce}, \mathrm{U}$, and $\mathrm{Th}$ in zircon.

\subsection{Experimental}

The sol-gel method used to prepare the starting materials is similar to that developed by Haaker and Ewing (1982). ${ }^{84}$ The detailed description of the sol-gel method was provided in the previous report (ref. 12). Stoichiometric amounts of $(\mathrm{EtO})_{4} \mathrm{Si}$, zirconyl oxynitrate $\mathrm{ZrO}\left(\mathrm{NO}_{3}\right)_{2} \cdot 2 \mathrm{H}_{2} \mathrm{O}$, cerium ammonium nitrate $\left(\mathrm{NH}_{4}\right)_{2} \mathrm{Ce}\left(\mathrm{NO}_{3}\right)_{6}$, uranyl nitrate $\mathrm{UO}_{2}\left(\mathrm{NO}_{3}\right)_{2} \cdot 6 \mathrm{H}_{2} \mathrm{O}$ or $\mathrm{ThCl}_{4} \cdot \mathrm{xH}_{2} \mathrm{O}$ were weighed. The stoichiometric amount of zirconyl oxynitrate and cerium ammonium nitrate (or uranyl nitrate or $\mathrm{ThCl}_{4} \cdot \mathrm{xH}_{2} \mathrm{O}$ respectively), were dissolved in methanol. Then tetraethoxysilane was added. The solution became acidic due hydrolysis. The solutions were combined in teflon containers and aged at $25^{\circ} \mathrm{C}$ for 24 hours while being stirred with magnetic rods. After gelation, the gels were filtered and dried at $90^{\circ} \mathrm{C}$ for 24 hours. Then the dried gels were calcined at $250^{\circ} \mathrm{C}$ which resulted in the decomposition of the nitrate salts and dehydration. A final calcination were done at $900^{\circ} \mathrm{C}$ for 2 hours, and then the calcined gels were ball milled. The chemical stoichiometries of starting materials designed for zircon synthesis are listed in Table 15. The gels with five stoichiometries were prepared: $\left(\mathrm{Zr}_{0.9} \mathrm{Ce}_{0.1}\right) \mathrm{SiO}_{4},\left(\mathrm{Zr}_{0.5} \mathrm{Ce}_{0.5}\right) \mathrm{SiO}_{4}$, $\left(\mathrm{Zr}_{0.9} \mathrm{U}_{0.08}\right) \mathrm{SiO}_{4},\left(\mathrm{Zr}_{0.5} \mathrm{U}_{0.5}\right) \mathrm{SiO}_{4}$, and $\left(\mathrm{Zr}_{0.96} \mathrm{Th}_{0.04}\right) \mathrm{SiO}_{4}$.

The calcined gels after ball milling were either directly sintered in air or vacuum for 1 or 2 hours at temperatures between 1400 and $1700^{\circ} \mathrm{C}$ or cold pressed and then sintered in air at $1400{ }^{\circ} \mathrm{C}$ for 8 to 12 hours. For cold pressed samples, the gel powders were compacted at room temperature in a cylindrical die $(2.86 \mathrm{~cm}$ in diameter). A pressure of 80 MPa was applied for two hours. A cold pressed pellet weighed 20 grams.

$\mathrm{X}$-ray powder diffraction (XRD) measurements were made using $\mathrm{CuK} \alpha$ and $\operatorname{CoK} \alpha$ radiation on a Rigaku Denki diffractometer. The original Rigaku software was 
employed for a semi-quantitative estimate of the phase contents. Lattice constants refinement were done using quartz as an internal standard.

The influence of $\mathrm{pH}$ in the solution on the structure of the sintered products of the gels was investigated by Helean, Lutze and Ewing (1997) ${ }^{12}$. The result indicated that the structures of sintered products derived from acidic and alkaline solutions were identical.

Analytical electron microscopy (AEM) examinations of sintered products were performed on a JEM 2010 electron microscope equipped with an Oxford Link ISIS EDS system. The microscope was operated at $200 \mathrm{keV}$. AEM samples were either powders or ion milled thin films. Chemical compositions were calculated assuming the stoichiometry of oxides and were normalized to $100 \mathrm{wt}$. \%. The k-factors for $\mathrm{Zr}, \mathrm{U}$, and $\mathrm{Th}$ were calibrated in the laboratory. The analytical errors were $\pm 5 \%$. The experiments for synthesis of zircon solid solutions is summarized and illustrated in Figure 13.

Table 14. Designed zircon compositions, final products and cell paprameters for zircon solid solutions.

\begin{tabular}{|c|c|c|c|c|}
\hline \multirow{2}{*}{$\begin{array}{l}\text { Designed zircon } \\
\text { compositions } \\
\text { (gel) } \\
\end{array}$} & \multirow{2}{*}{$\begin{array}{l}\text { Sintering } \\
\text { conditions } \\
\mathrm{T},{ }^{\circ} \mathrm{C} / \text { time, } \mathrm{h}\end{array}$} & \multirow{2}{*}{$\begin{array}{c}\text { Final products } \\
\text { Zrn(ss) }=\text { zircon solid soln. } \\
\text { decreasing yield } \rightarrow\end{array}$} & \multicolumn{2}{|c|}{$\begin{array}{l}\text { Zircon solid solution } \\
\text { cell parameters, }(\AA)\end{array}$} \\
\hline & & & $a$ & \\
\hline $\mathrm{Zr}_{0.9} \mathrm{Ce}_{0.1} \mathrm{SiO}_{4}$ & air 1700/1 & $\mathrm{Zrn}(\mathrm{ss}), \mathrm{CZ}, \mathrm{Cr}, \mathrm{MZ}, \mathrm{TZ}$ & $6.606(1)$ & $5.980(1)$ \\
\hline $\mathrm{Zr}_{0.9} \mathrm{Ce}_{0.1} \mathrm{SiO}_{4}$ & air $1600 / 1$ & $\mathrm{Zrn}(\mathrm{ss}), \mathrm{MZ}, \mathrm{Cr}, \mathrm{TZ}, \mathrm{CZ}$ & $6.610(1)$ & $5.983(1)$ \\
\hline $\mathrm{Zr}_{0.9} \mathrm{Ce}_{0.1} \mathrm{SiO}_{4}$ & air $1500 / 1$ & $\mathrm{Zrn}(\mathrm{ss}), \mathrm{MZ}, \mathrm{TZ}, \mathrm{Cr}, \mathrm{CZ}$ & $6.609(1)$ & $5.979(2)$ \\
\hline $\mathrm{Zr}_{0.9} \mathrm{Ce}_{0.1} \mathrm{SiO}_{4}$ & air $1400 / 1$ & $\mathrm{MZ}, \mathrm{TZ}, \mathrm{Zn}(\mathrm{ss})$ & $6.618(2)$ & $5.987(2)$ \\
\hline $\mathrm{Zr}_{0.9} \mathrm{Ce}_{0.1} \mathrm{SiO}_{4}$ & air 1400/8 & $\mathrm{Znn}(\mathrm{ss}), \mathrm{CZ}, \mathrm{TZ}, \mathrm{Cr}$ & & \\
\hline $\mathrm{Zr}_{0.5} \mathrm{Ce}_{0.5} \mathrm{SiO}_{4}$ & air $1400 / 8$ & $\mathrm{CZ}, \mathrm{Zrn}(\mathrm{ss}), \mathrm{Cr}$ & & \\
\hline $\mathrm{Zr}_{0.9} \mathrm{Ce}_{0.1} \mathrm{SiO}_{4}$ & air $1400 / 12$ & $\mathrm{Znn}(\mathrm{ss}), \mathrm{CZ}, \mathrm{TZ}, \mathrm{Cr}$ & & \\
\hline $\mathrm{Zr}_{0.92} \mathrm{U}_{0.08} \mathrm{SiO}_{4}$ & vacuum $1500 / 2$ & $\mathrm{MZ}, \mathrm{Zrn}(\mathrm{ss}), \mathrm{TZ}, \mathrm{Cr}$ & $6.621(1)$ & $5.993(1)$ \\
\hline $\mathrm{Zr}_{0.92} \mathrm{U}_{0.08} \mathrm{SiO}_{4}$ & vacuum $1400 / 2$ & $\mathrm{MZ}, \mathrm{Zrn}(\mathrm{ss}), \mathrm{TZ}, \mathrm{Cr}$ & $6.617(1)$ & $5.995(1)$ \\
\hline $\mathrm{Zr}_{0.5} \mathrm{U}_{0.5} \mathrm{SiO}_{4}$ & vacuum $1500 / 2$ & $\mathrm{CZ}, \mathrm{TZ}, \mathrm{Zrn}(\mathrm{ss}), \mathrm{Cr}, \mathrm{U}$ & $6.621(1)$ & $6.000(2)$ \\
\hline $\mathrm{Zr}_{0.5} \mathrm{U}_{0.5} \mathrm{SiO}_{4}$ & vacuum $1400 / 2$ & $\mathrm{CZ}, \mathrm{TZ}, \mathrm{Zrn}(\mathrm{ss}), \mathrm{Cr}, \mathrm{U}$ & $6.617(1)$ & $5.993(1)$ \\
\hline $\mathrm{Zr}_{0.96} \mathrm{Th}_{0.04} \mathrm{SiO}_{4}$ & vacuum $1400 / 2$ & $\mathrm{MZ}, \mathrm{Zrn}(\mathrm{ss}), \mathrm{TZ}, \mathrm{T}, \mathrm{Thr}, \mathrm{Cr}$ & $6.614(2)$ & $6.000(2)$ \\
\hline $\mathrm{Zr}_{0.96} \mathrm{Th}_{0.04} \mathrm{SiO}_{4}$ & vacuum $1550 / 2$ & $\mathrm{Zrn}(\mathrm{ss}), \mathrm{MZ}, \mathrm{TZ}, \mathrm{T}, \mathrm{Thr}, \mathrm{Ht}, \mathrm{Cr}$ & $6.614(1)$ & $5.987(1)$ \\
\hline
\end{tabular}

$\mathrm{Cr}=$ cristobalite $\left(\mathrm{SiO}_{2}\right) ; \quad \mathrm{CZ}=$ cubic $\quad(\mathrm{A}, \quad \mathrm{Zr}) \mathrm{O}_{2}$ ss.; TZ=tetragonal $\quad(\mathrm{Zr}, \mathrm{A}) \mathrm{O}_{2}$ ss.; $\mathrm{MZ}=$ monoclinic $(\mathrm{Zr}, \mathrm{A}) \mathrm{O}_{2} \mathrm{sS}$; $\quad \mathrm{U}=\mathrm{UO}_{2.25} ; \mathrm{T}=\mathrm{ThO}_{2} ; \mathrm{Thr}=\mathrm{ThSiO}_{4}$ thorite; $\mathrm{Ht}=\mathrm{ThSiO}_{4}$ huttonite. 


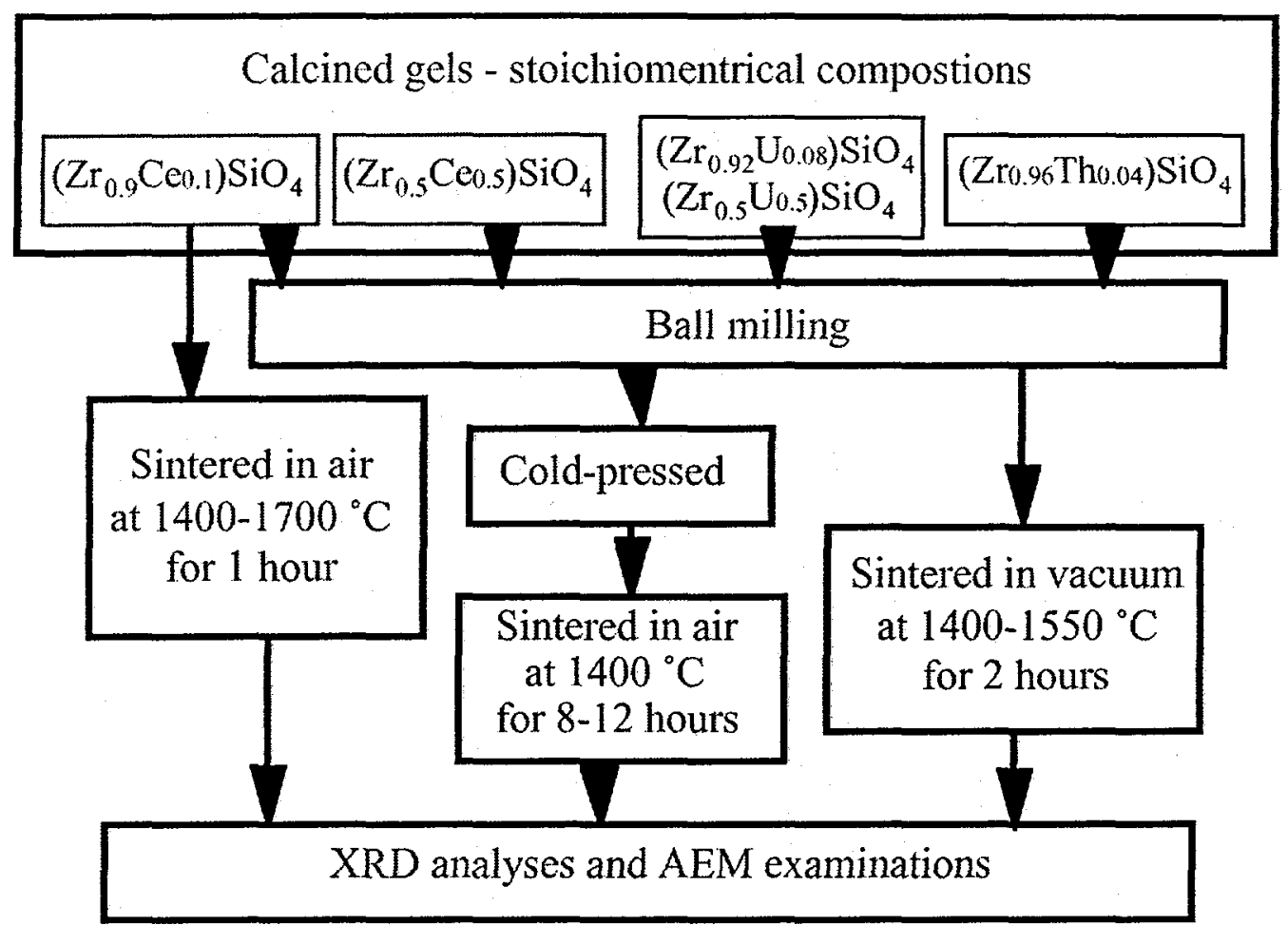

Figure 13. Experimental flow sheet for synthesis of zircon solid solutions

\subsection{Microstructures and phase constituents of sintered products}

The phase constituents for the sintered powders and the cell parameters for zircon solid solutions are listed in Table 14. In addition to zircon solid solutions, the sintered powders contain:

1. Tetragonal $(\mathrm{Zr}, \mathrm{A}) \mathrm{O}_{2}$ solid solutions where $\mathrm{A}$ represents $\mathrm{Ce}^{4+}, \mathrm{U}$, and $\mathrm{Th}$ respectively; tetragonal zirconia in all compositions, except $\left(\mathrm{Zr}_{0.5} \mathrm{Ce}_{0.5}\right) \mathrm{O}_{2}$.

2. Cubic $(\mathrm{Zr}, \mathrm{A}) \mathrm{O}_{2}$ solid solutions in the gels doped with 10 and $50 \mathrm{wt} . \%$ of $\mathrm{Ce}^{4+}$ and with 50 wt. $\%$ of $\mathrm{U}^{4+}$, respectively.

\section{Monoclinic $\mathrm{ZrO}_{2}$.}

4. Actinide oxides, e.g., $\mathrm{UO}_{2.25}$ in the samples with the initial $50 \mathrm{wt} \%$ of uranium initially; $\mathrm{ThO}_{2}$ in the $\mathrm{Th}$ doped samples.

The phase contents depend on the initial compositions of the gels. Cubic $(\mathrm{Zr}, \mathrm{U}) \mathrm{O}_{2}$ solid solutions occur only in the gels with higher uranium, as in $\left(\mathrm{Zr}_{0.5} \mathrm{U}_{0.5}\right) \mathrm{SiO}_{4}$. The tetragonal and monoclinic zirconia dominate the gels with lower uranium as in 
$\left(\mathrm{Zr}_{0.92} \mathrm{U}_{0.08}\right) \mathrm{SiO}_{4}$. Another example are the gels doped with cerium. Monoclinic and tetragonal zirconia phases are more abundant than cubic $(\mathrm{Zr}, \mathrm{Ce}) \mathrm{O}_{2}$ in $\left(\mathrm{Zr}_{0.9} \mathrm{Ce}_{0.1}\right) \mathrm{SiO}_{4}$, whereas the cubic phase is the dominant zirconia phase in $\left(\mathrm{Zr}_{0.5} \mathrm{Ce}_{0.5}\right) \mathrm{SiO}_{4}$. This is consistent with the $\mathrm{ZrO}_{2}-\mathrm{CeO}_{2}$ phase diagram. ${ }^{85}$ The phase content also depends on the sintering temperature. As we can see in Table 14, the gel with the composition $\left(\mathrm{Zr}_{0.9} \mathrm{Ce}_{0.1}\right) \mathrm{SiO}_{4}$ produces more cubic phase at $1700^{\circ} \mathrm{C}$ than at $1500^{\circ} \mathrm{C}$.

For the gel with the composition $\left(\mathrm{Zr}_{0.9} \mathrm{Ce}_{0.1}\right) \mathrm{SiO}_{4}$, the zircon yield reached $90 \mathrm{wt} . \%$ at temperatures between 1400 and $1600{ }^{\circ} \mathrm{C}$. However, for the gels with other compositions, the zircon yields were substantially lower, $\sim 30 \mathrm{wt}$. \%. Figure 14 is a TEM micrograph showing the microstructure of the gel powders with the composition $\left(\mathrm{Zr}_{0.5} \mathrm{U}_{0.5}\right) \mathrm{SiO}_{4}$ sintered in vacuum at $1500{ }^{\circ} \mathrm{C}$ for one hour. The sintered product consisted mainly of spherical $(\mathrm{Zr}, \mathrm{U}) \mathrm{O}_{2}$ crystallites of cubic structure and cristobalite particles. Figure 15 shows the microstructure of a zircon ceramic obtained after sintering a cold-pressed $\left(\mathrm{Zr}_{0.9} \mathrm{Ce}_{0.1}\right) \mathrm{SiO}_{4}$ gel in air at $1400{ }^{\circ} \mathrm{C}$ for 8 hours. In this ceramic, there are three crystalline phases, zircon solid solution $(\mathrm{Zr}, \mathrm{Ce}) \mathrm{SiO}_{4}$, zirconia solid solution $(\mathrm{Zr}, \mathrm{Ce}) \mathrm{O}_{2}$, and cristobalite. $\mathrm{XRD}$ and electron diffraction analyses show that the zirconia is the mixture of cubic and tetragonal phases. In the gel sample with the composition $\left(\mathrm{Zr}_{0.9} \mathrm{Ce}_{0.1}\right) \mathrm{SiO}_{4}$ after sintering at $1400{ }^{\circ} \mathrm{C}$ for 12 hours, zircon $(\mathrm{Zr}, \mathrm{Ce}) \mathrm{SiO}_{4}$ is the dominant phase. The zircon crystals grew in size. They are $-4 \mu \mathrm{m}$ in size in the sample sintered for 8 hours (Figure 15) and more than $8 \mu \mathrm{m}$ in size (Figure 16a) after 12 hours. Zirconia phases appear as tiny inclusions in the large zircon grains (Figure 16b). In particular, EDS analysis shows that cerium dominates over zirconium in concentration in this solid solution $(\mathrm{Ce}, \mathrm{Zr}) \mathrm{O}_{2}$. The inclusions are less than $1 \mu \mathrm{m}$ in size. 


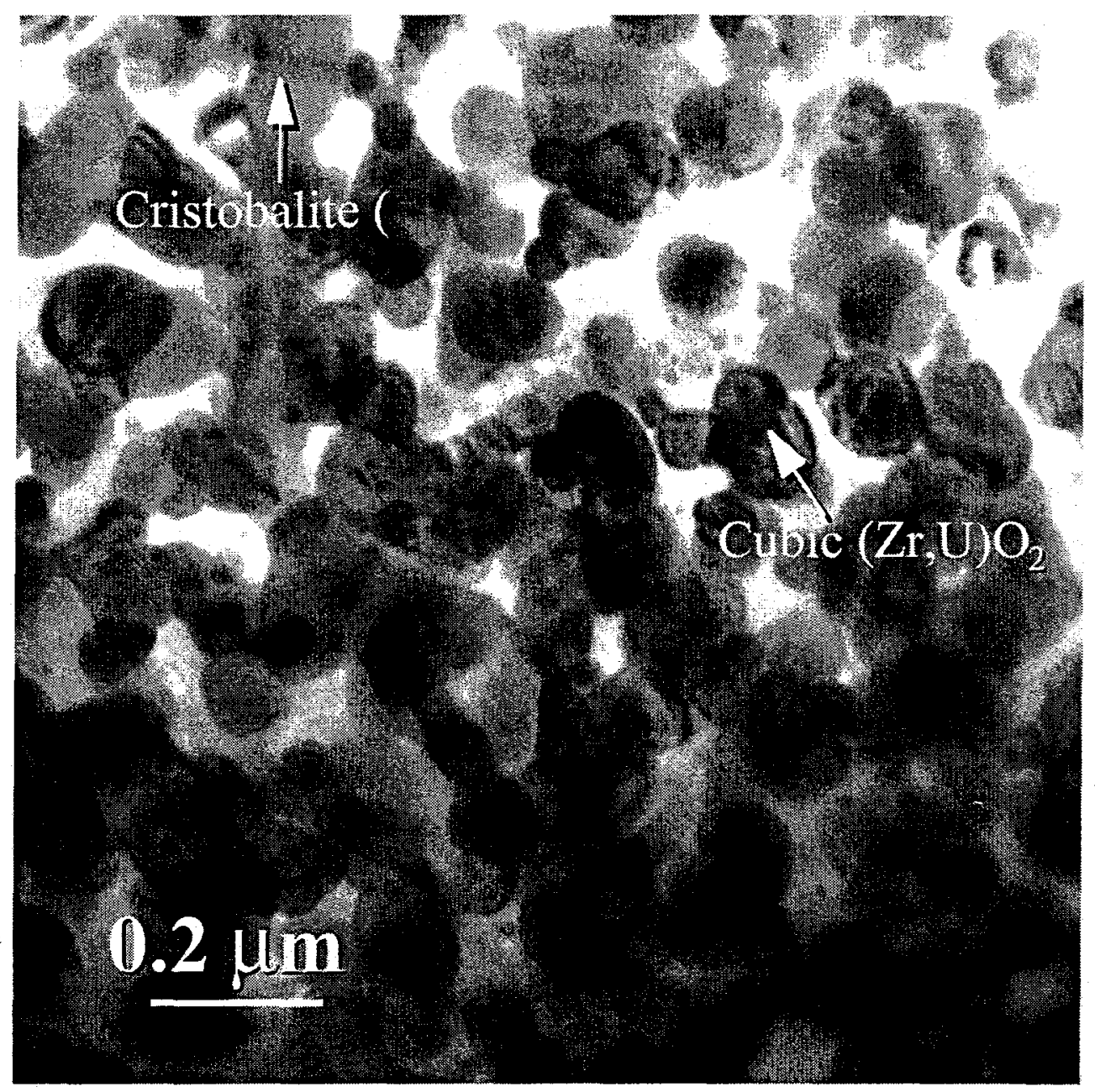

Fig. 14. The microstructure of the gel powders sintered in vacuum at $1500^{\circ} \mathrm{C}$. The particles with dark contrast and bending contours are zirconia. The other particles with homogeneous gray contrast are cristobalite. 


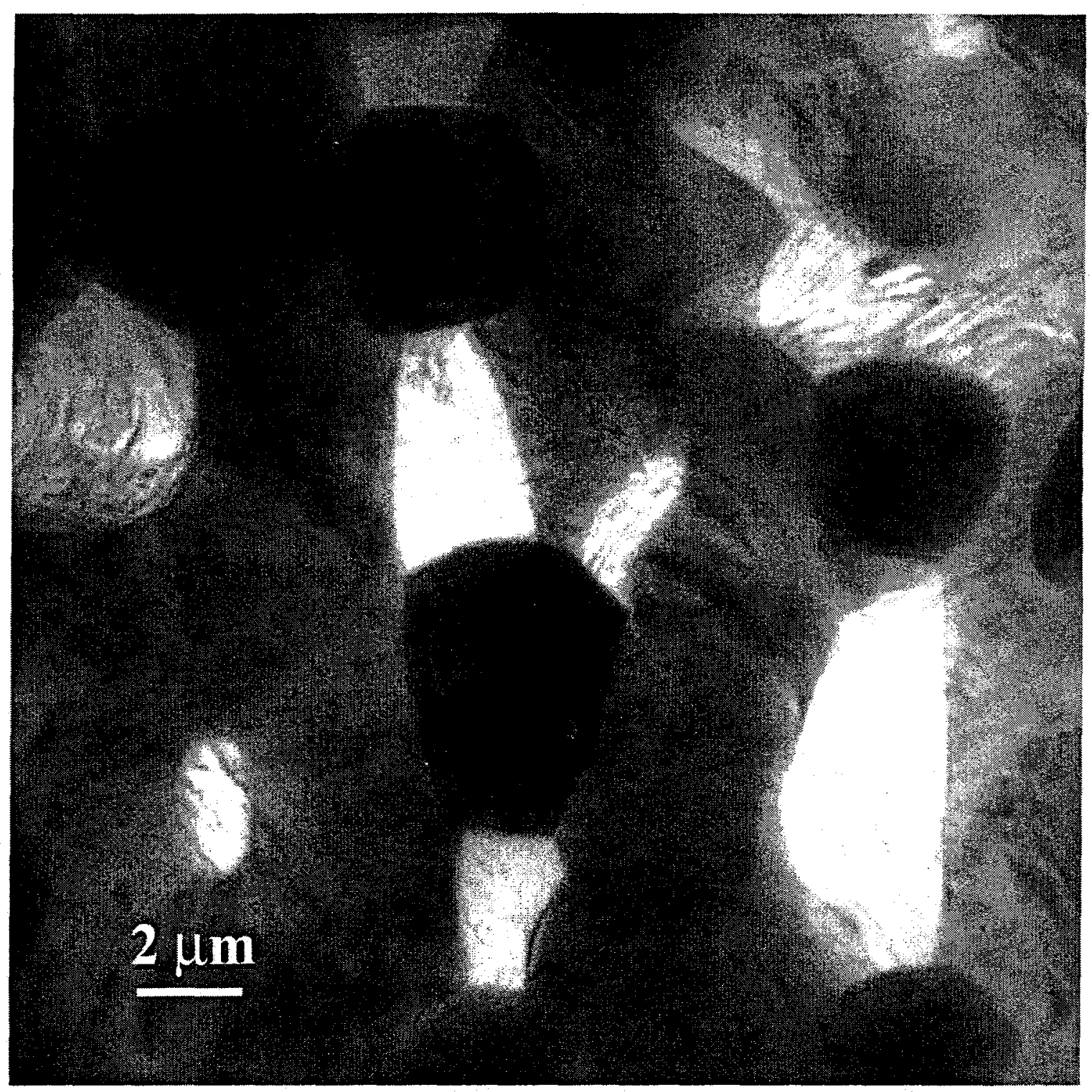

Figure 15. Microstructure of the $\left(\mathrm{Zr}_{0.9} \mathrm{Ce}_{0.1}\right) \mathrm{SiO}_{4}$ gel sintered in air at $1400^{\circ} \mathrm{C}$ for 8 hours. The gray grains are $(\mathrm{Zr}, \mathrm{Ce}) \mathrm{SiO}_{4}$, dark grains are $(\mathrm{Zr}, \mathrm{Ce}) \mathrm{O}_{2}$, and white grains are cristobalite. 


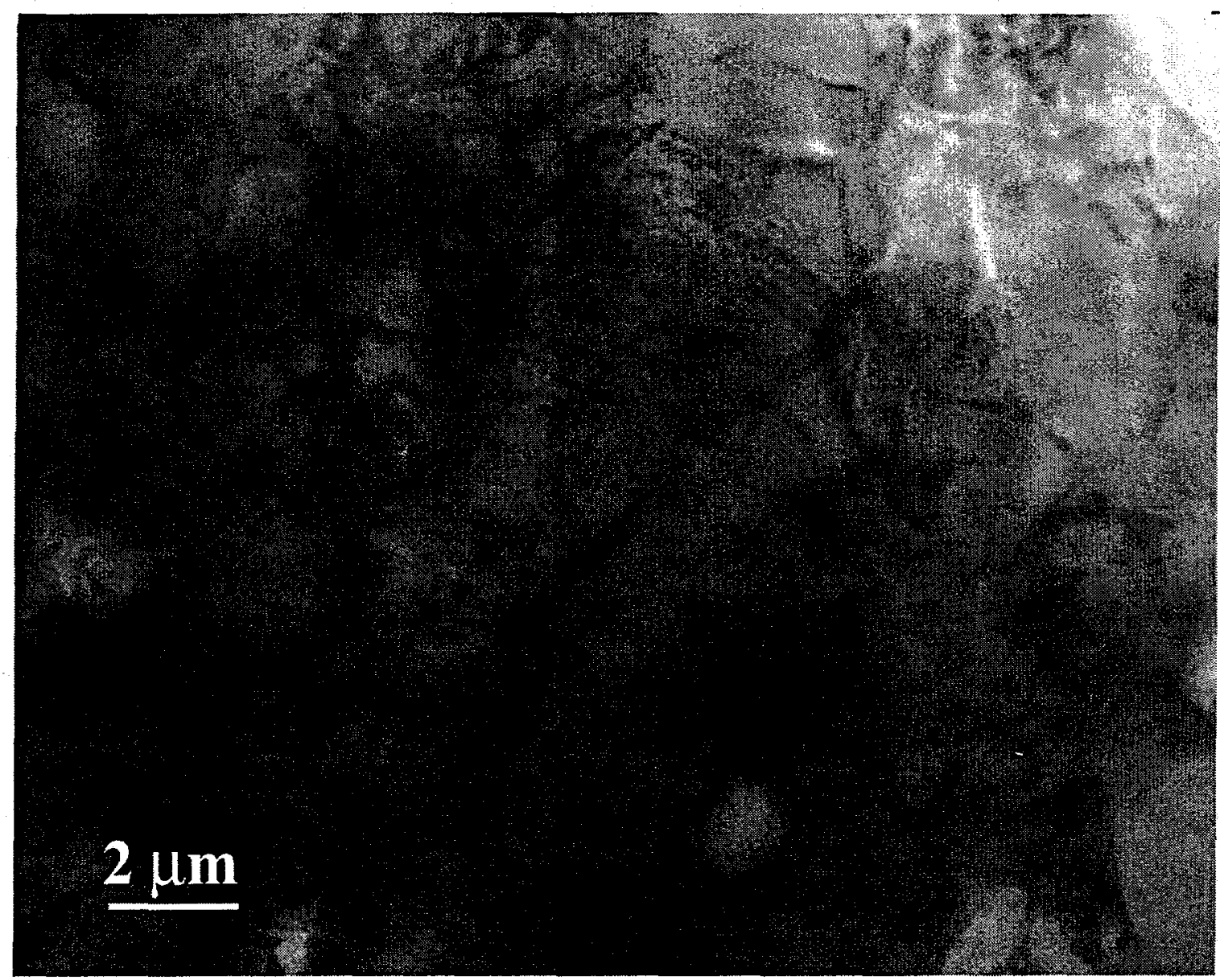

Fig. 16a. Microstructure of $\left(\mathrm{Zr}_{0.9} \mathrm{Ce}_{0.1}\right) \mathrm{SiO}_{4}$ gel sintered for 12 hours at $1400^{\circ} \mathrm{C}$ in air. 


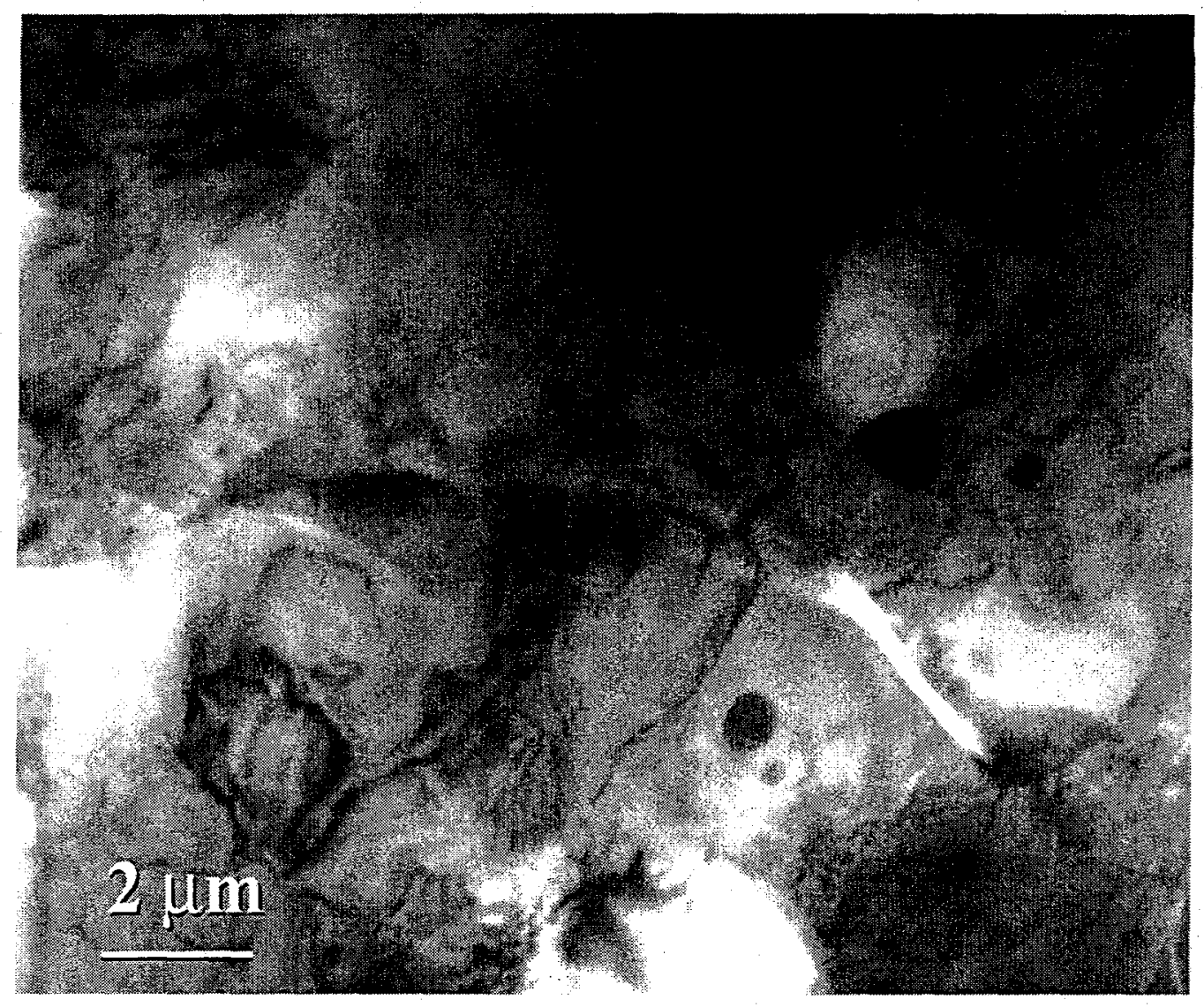

Fig. 16b. Microstructure of $\left(\mathrm{Zr}_{0.9} \mathrm{Ce}_{0.1}\right) \mathrm{SiO}_{4}$ gel sintered for 12 hours at $1400^{\circ} \mathrm{C}$ in air. The dark spots in zircon grains indicate $(\mathrm{Ce}, \mathrm{Zr}) \mathrm{O}_{2}$ inclusions.

To understand the mechanism of zircon formation, concentrations (in wt \%) of the crystalline phases (zircon, tetragonal and monoclinic zirconia, and cristobalite) were measured as a function of sintering temperature for the unmilled samples of $\left(\mathrm{Zr}_{0.9} \mathrm{Ce}_{0.1}\right) \mathrm{SiO}_{4}$ gel (Figure 17). After sintering the $\left(\mathrm{Zr}_{0.9} \mathrm{Ce}_{0.1}\right) \mathrm{SiO}_{4}$ gel, tetragonal zirconia comprised approximately $90 \mathrm{wt} \%$ of the sintering products. At $1400{ }^{\circ} \mathrm{C}$, there was a significant decrease in tetragonal zirconia, whereas zircon formation was measured at $\sim 22$ wt.\%. At $1500{ }^{\circ} \mathrm{C}$, there was a significant increase in zircon content ( $\left.90 \mathrm{wt} . \%\right)$ accompanied by a substantial decrease in tetragonal zirconia. Monoclinic zirconia is relatively low in content $(<10 \mathrm{wt} . \%)$. Apparently, zircon formation takes place at the expense of tetragonal zirconia and cristobalite with increasing sintering temperature. Zirconia occurred as tetragonal $(\mathrm{Zr}, \mathrm{Ce}) \mathrm{O}_{2}$ as seen in Figure 17. The zircon formation is the result of an interfacial reaction between $\mathrm{T}-(\mathrm{Zr}, \mathrm{Ce}) \mathrm{O}_{2}$ and $\mathrm{SiO}_{2}$ and this process is promoted by increasing temperature. As we see in Figures 15 and 16, sintering time is 
also an important factor controlling zircon formation. At $1400{ }^{\circ} \mathrm{C}$ for 8 hours (Figure 15), the ceramic consists of three crystalline phases, tetragonal $(\mathrm{Zr}, \mathrm{Ce}) \mathrm{O}_{2}$, cristobalite and zircon. After sintering for 12 hours, zircon dominates. Because the solubility of $\mathrm{CeSiO}_{4}$ in zircon is less than $10 \mathrm{~mole} \%$, the remaining zirconia becomes more concentrated in $\mathrm{Ce}$ (Figure 16b) and occurs as small inclusions in zircon grains.

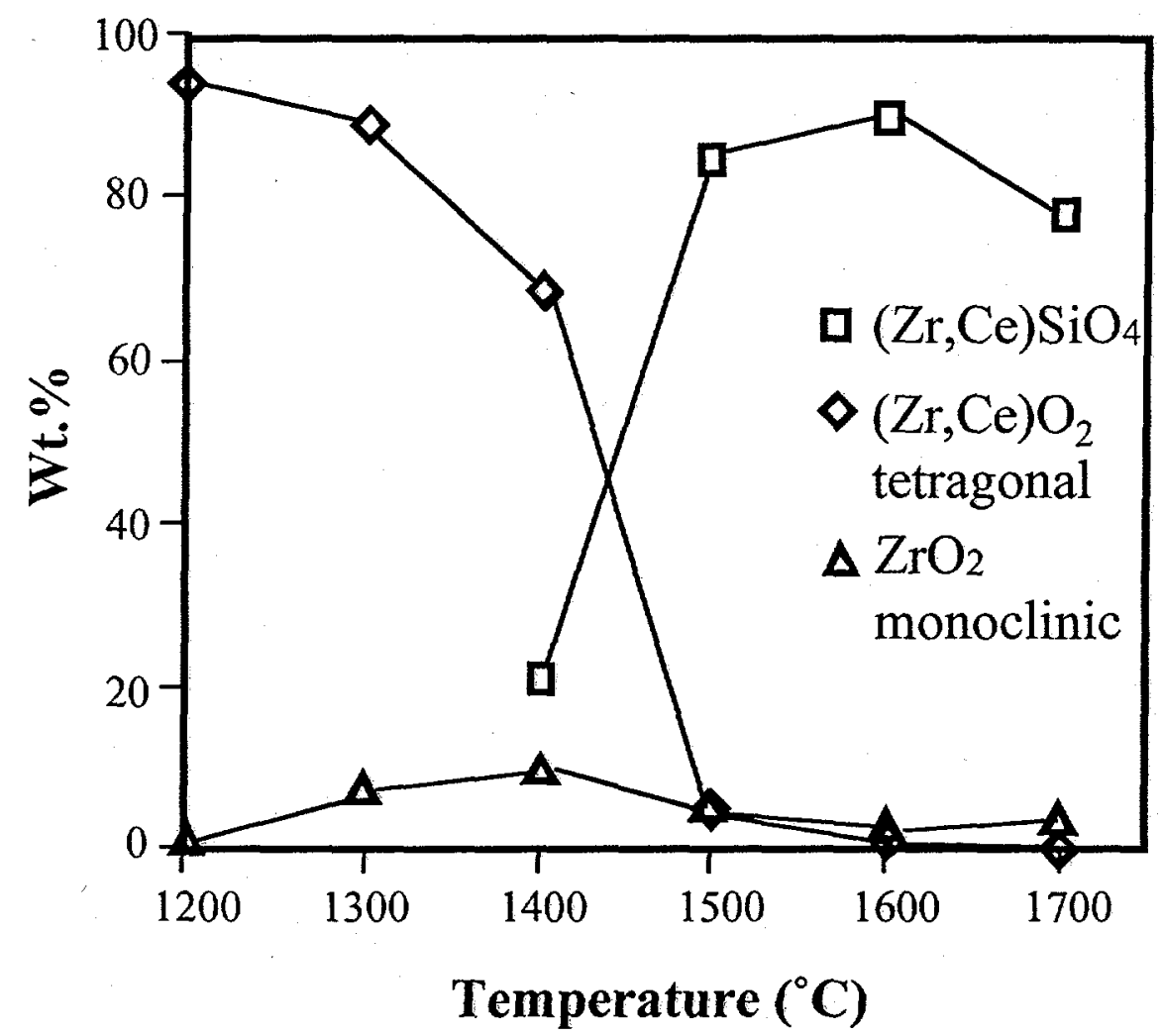

Figure 17. Weight percents of monoclinic, tetragonal zirconia and zircon as a function of temperature [ $\left(\mathrm{Zr}_{0.9} \mathrm{Ce}_{0.1}\right) \mathrm{SiO}_{4}$ gel, sintered in air for 1 hour].

\subsection{Solubility of actinides in zircon}

AEM studied were conducted on (1) the $\left(\mathrm{Zr}_{0.9} \mathrm{Ce}_{0.1}\right) \mathrm{SiO}_{4}$ gel (cold pressed) sintered at $1400^{\circ} \mathrm{C}$ for 8 and 12 hours; (2) the $\left(\mathrm{Zr}_{0.5} \mathrm{Ce}_{0.5}\right) \mathrm{SiO}_{4}$ gel (powders) sintered at $1400{ }^{\circ} \mathrm{C}$ for 8 hours; and (3) the $\left(\mathrm{Zr}_{0.92} \mathrm{Ce}_{0.08}\right) \mathrm{SiO}_{4}$ gel (powders) sintered at $1500^{\circ} \mathrm{C}$ for 2 hours.

The results of AEM analyses of these samples are compiled in Table 16. The cerium contents in zircon vary between 4.3 to $7.8 \mathrm{wt} . \% \mathrm{CeO}_{2}$ from grain to grain for the $\left(\mathrm{Zr}_{0.9} \mathrm{Ce}_{0.1}\right) \mathrm{SiO}_{4}$ gel. The average of all the measurements gives $6.7 \pm 1 \mathrm{~mole} \%$ " $\mathrm{CeSiO}_{4}$ " in 
zircon. Zircon with these " $\mathrm{CeSiO}_{4}$ " concentrations coexists with $(\mathrm{Zr}, \mathrm{Ce}) \mathrm{O}_{2}$ or $(\mathrm{Ce}, \mathrm{Zr}) \mathrm{O}_{2}$ in the samples sintered at $1400^{\circ} \mathrm{C}$ for 8 hours and 12 hours, indicating that the $6.7 \pm 1 \%$ represents the solubility limit of " $\mathrm{CeSiO}_{4}$ " in zircon. The $\left(\mathrm{Zr}_{0.5} \mathrm{Ce}_{0.5}\right) \mathrm{SiO}_{4}$ sample sintered at $1400{ }^{\circ} \mathrm{C}$ for 8 hours gives a similar result: $7.1 \pm 1 \mathrm{~mole} \%$ "CeSiO ${ }_{4}$ " in zircon. The solubility data obtained from two gel compositions, $\left(\mathrm{Zr}_{0.9} \mathrm{Ce}_{0.1}\right) \mathrm{SiO}_{4}$ and $\left(\mathrm{Zr}_{0.5} \mathrm{Ce}_{0.5}\right) \mathrm{SiO}_{4}$ do not make a significant difference. The " $\mathrm{CeSiO}_{4}$ " solubility in zircon at temperatures higher than $1400{ }^{\circ} \mathrm{C}$ is difficult to evaluate, because the $\mathrm{Ce}^{4+}$ is reduced to $\mathrm{Ce}^{3+}$ in significant quantity.

Table 16. AEM results on zircon solid solutions with $\mathrm{Ce}^{4+}, \mathrm{U}^{4+}$, and $\mathrm{Th}^{4+}$

\begin{tabular}{|l|l|l|l|l|}
\hline $\begin{array}{l}\text { nominal } \\
\text { compositions }\end{array}$ & $\begin{array}{l}\text { sintering } \\
\text { condition }\end{array}$ & $\begin{array}{l}\mathrm{AO}_{2} \text { range/av.* "ASiO } \\
(w t . \%)\end{array}$ & $\begin{array}{l}\text { " range// } \\
\text { av. (mole\%) }\end{array}$ & $\begin{array}{l}\text { analytical } \\
\text { number }\end{array}$ \\
\hline $\mathrm{Zr}_{0.9} \mathrm{Ce}_{0.1} \mathrm{SiO}_{4}$ & $1400^{\circ} \mathrm{C} / 12 \mathrm{hr}$ & $4.3-7.8 / 6.2$ & $4.6-8.6 / 6.7$ & 19 \\
\hline $\mathrm{Zr}_{0.5} \mathrm{Ce}_{0.5} \mathrm{SiO}_{4}$ & $1400^{\circ} \mathrm{C} / 8 \mathrm{hr}$ & $5.8-7.6 / 6.5$ & $6.3-8.2 / 7.1$ & 8 \\
\hline $\mathrm{Zr}_{0.92} \mathrm{U}_{0.08} \mathrm{SiO}_{4}$ & $1500^{\circ} \mathrm{C} / 2 \mathrm{hr}$ & $4.8-7.3 / 6.3$ & $3.2-5.1 / 4.1$ & 11 \\
\hline $\mathrm{Zr}_{0.96} \mathrm{Th}_{0.04} \mathrm{SiO}_{4}$ & $1500^{\circ} \mathrm{C} / 2 \mathrm{hr}$ & & av. 2.0 & 6 \\
\hline
\end{tabular}

*av: average.

AEM measurements on the $\left(\mathrm{Zr}_{0.92} \mathrm{U}_{0.08}\right) \mathrm{SiO}_{4}$ sample yielded 4.8-7.3 wt.\% of $\mathrm{UO}_{2}$, corresponding to 3.2-5.1 mole\% of $\mathrm{USiO}_{4}$ in zircon. Assuming a straight-line relationship for unit-cell parameters between two end-member compounds in a solid solution system, Mumpton and Roy $(1961)^{43}$ estimated zircon compositions based on the change of zircon compositions as a function of the (200) d-spacing. In this work we used three endmember compositions, $\mathrm{ZrSiO}_{4}, \mathrm{ThSiO}_{4}$ and $\mathrm{USiO}_{4}$ to estimate the zircon compositions based on the linear change of zircon composition as a function of unit-cell parameters. The calculations gave $4 \mathrm{~mole}^{2}$ of $\mathrm{USiO}_{4}$ and $2 \mathrm{~mole} \%$ of $\mathrm{ThSiO}_{4}$ in zircon, respectively. The solubility data are summarized in Figure 18. The solubility limit of $\mathrm{PuSiO}_{4}$ in zircon is not known exactly. The highest concentration of $\mathrm{Pu}$ in zircon reported in the literature is 9.2 wt.\%. We estimate that the solubility limit of $\mathrm{PuSiO}_{4}$ is higher than but close to that of "CeSiO 


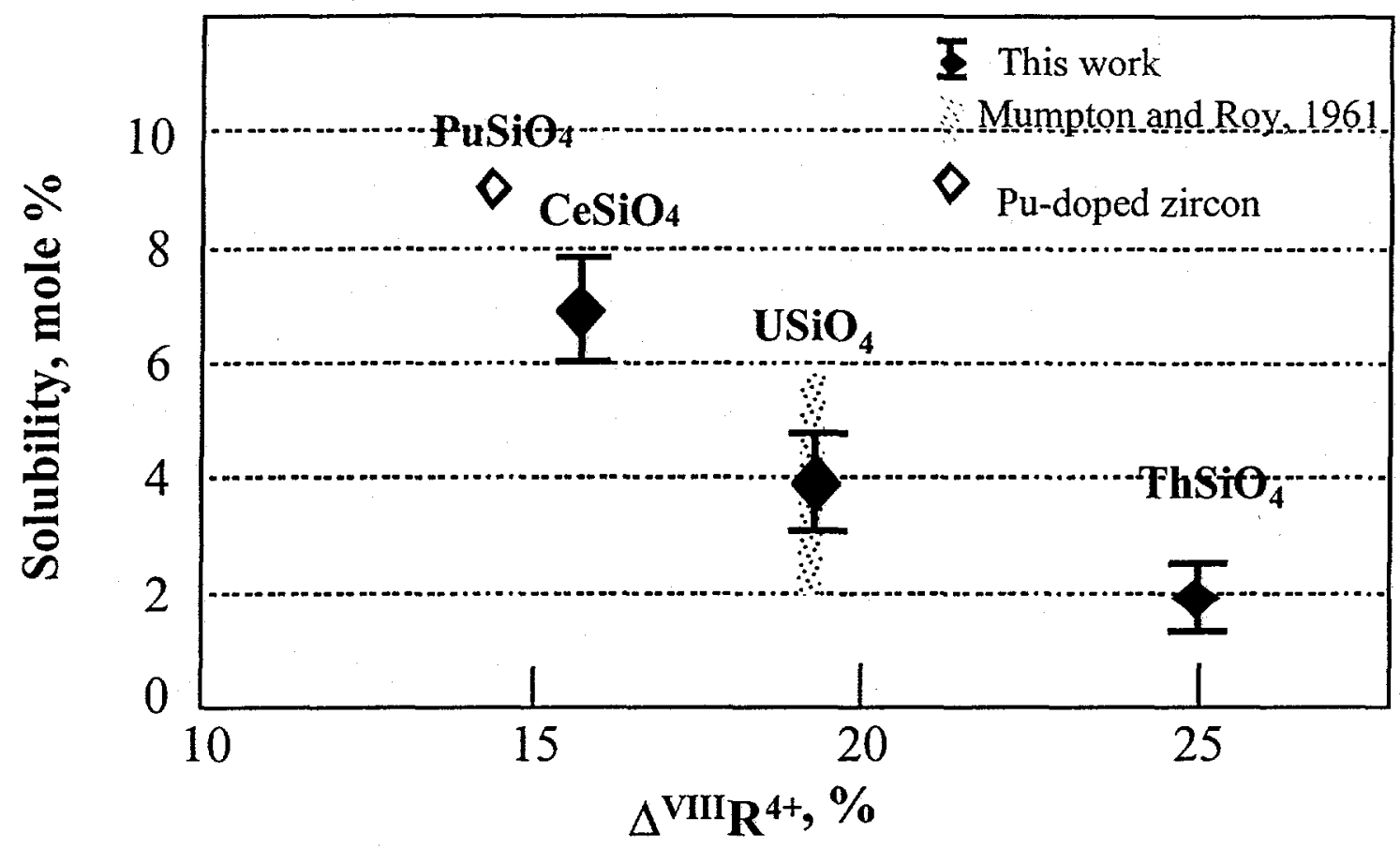

Figure 18. Solubility limits of " $\mathrm{CeSiO}_{4}$ " $\left(1400^{\circ} \mathrm{C}\right), \mathrm{USiO}_{4}\left(1400-1500^{\circ} \mathrm{C}\right)$ and $\mathrm{ThSiO}_{4}$ $\left(1400-1550^{\circ} \mathrm{C}\right)$ in zircon. $\Delta^{\mathrm{VIII}} \mathrm{IR}^{4+}=100\left(\mathrm{R}_{\mathrm{i}}-\mathrm{R}_{\mathrm{Zr}}\right) / \mathrm{R}_{\mathrm{Zr}}$, where $\mathrm{R}$ is ionic radius; $\mathrm{i}$ is $\mathrm{Pu}, \mathrm{Ce}, \mathrm{U}$, and $\mathrm{Th}$. Dotted lines indicate the results by Mumpton and Roy (1961, ref. 43) 


\section{References}

1. National Academy of Sciences (1994) Management and Disposition of Excess Weapons Plutonium, National Academy Press, Washington D.C.

2. Stoll, W. (1998) What are the options for disposition of excess weapons Pu?, MRS Bull., 23, 3, 6-16.

3. Ferguson, D. E. (1977) Simple quick processing plant, memo to Floyd Culler, August 30, ORNL, USA

4. Dzekun, E. and Romanovsky, V. (1996) Partitioning installation in Russia is operable, Russian Minatom Monitor, August 19.

5. Armantrout, G., Gray, L. W. and Myers, B. (1998) Plutonium immobilization form evaluation, WM'98 CD-ROM, paper 65-1.

6. Lutze, W. and Ewing, R. C., eds. (1988) Radioactive Waste Forms for the Future, North Holland, N. Y.

7. Ewing, R. C., Lutze, W. and Weber, W. J. (1995) Zircon: A host-phase for the disposal of weapons plutonium, J. Materials Res. 10, No. 2, 243-246.

8. Vettraino, F., Lombardi, C. and Mazzola, A. (1997) Inert matrix non-fertile fuels for plutonium transmutation in PWRs, Plutonium Futures - The Science, Conference Transactions, LANL, 34-34.

9. Stoll, W. (1996) German Patent Nr. DE 19526776 A1, Internat. classification C $01 \mathrm{G} 56 / 00$ gehört.

10. Ebbinghaus, B. B., VanKonynenburg, R. A., Ryerson, F.J. Vance, E. R., Stewart, M. W. A., Jostsons, A., Alander, J. S., Rankin. T. and Congdon, J. (1998) Ceramic formulation for the immobilization of plutonium, $W M^{\prime} 98 \mathrm{CD}$ $R O M$, paper 65-4.

11. Helean K. B., Ewing R. C., and Lutze W., Zircon: A summary of previous studies relevant to the evaluation of chemical and mechanical durability, Annual Report to Los Alamos National Laboratory, 1996.

12. Helean K. B., Lutze W., and Ewing R. C., The synthesis and chemical durability of zircon as a host phase for Pu, Annual Report to Los Alamos National Laboratory, 1997.

13. Ewing, R. C. Weber, W. J. and Lutze, W., (1996) Crystalline ceramics: Waste forms for the disposal of Weapons Plutonium, Disposal of Weapon Plutonium, Merz, E.R. and Walter, C.E., eds., Kluwer Academic Publishers, Dordrecht.

14. Weber, W. J., Wald, J. W. and Matzke, Hj. (1985) Self-irradiation damage in $\mathrm{Gd}_{2} \mathrm{Ti}_{2} \mathrm{O}_{7}$, Mat. Letters 3, 173-180.

15. Weber, W. J., Wald, J. W. and Matzke, Hj. (1986) Effects of self-irradiation damage in $\mathrm{Cm}$-doped $\mathrm{Gd}_{2} \mathrm{Ti}_{2} \mathrm{O}_{7}$ and CaZrTi2O7, J. Nucl. Materials 138, 196-209. 
16. Ewing, R. C., Haaker, R. F., Headley. T. J. and Hlava, P. (1982) Zirconolites from Sri Lanka, South Afrika and Brasil, Mat. Res. Soc. Symp. Proc., Topp, S. V., ed., 6, 249-256, North Holland, New York.

17. Ewing, R. C.and Headley, R. F. (1983) Alpha-recoil damage in natural zirconolite $\left(\mathrm{CaZrTi}_{2} \mathrm{O}_{7}\right)$, J. Nucl. Materials 119, 102-109.

18. Oversby, V. M. and Ringwood, A. E. (1981)Lead isotopicstudies of zirconolite and perovskite and their implications for long-range Synroc stability, Rad. Waste Management 1,289-308.

19. Sinclair, W. and Ringwood, A. E. (1981) Alpha-recoil damage in natural zirconolite and perovskite, Geochemical Journal 15,229-243.

20. Weber, W. J., Turcotte, R. P., Bunnell, L. R., Roberts, F. P. and Westsik, J. H. (1979) Radiation effects in vitreous and devitrified simulated waste glass, Ceramics in Nuclear Waste Management, Chikalla, T. D. and Mendel, J. E., eds., CONF 790420, Nat. Techn Information Service, Springfield, Virginia, 294-299.

21. Weber, W. J., Turcotte, R. P., Wald, J. W., Roberts, F. P., Rusin, J. M. and Lutze, W. (1982), Radiation damage in nuclear waste ceramics, J. Amer. Ceram. Soc. 65, 589-593.

22. Dé, A.K., Luckscheiter, B., Lutze, W., Malow, G. and Schiewer, E. (1976) Development of glass ceramics for the incorporation of fission products, Ceramic Bulletin 55, 500-503

23. Lindberg, M. L. and Ingram, B. (1964) Rare-earth silicate apatite from the Adirondack Mountains, New York, Professional Paper 501-B, U.S. Geological Survey, 64-65

24. Gong, W. L., Wang, L. M., Ewing, R. C., Chen L. F., and Lutze, W.(1996) Transmission Electron Microscopy of a.-Decay Damage in Aeschynite and Britholite, Mat. Res. Soc. Symp. Proc., XX, 649-656.

25. Koul, S. L. (1979) On the fission track dating and annealing behaviour of accessory minerals of eastern Ghats (Andhra Pradesh, India), Radiation Effects $40,187-192$.

26. Sales, B. and Boatner,.L. (1988) in ref. [6].

27. Karioris, F. G., Gowda, K. A. and Kartz, L. (1981) Heavy ion bombardment of monoclinic $\mathrm{ThSiO}_{4}$, $\mathrm{ThO}_{2}$, and monazite, Radiation Effects Letters 58, 1-3.

28. Gong, W., Lutze, W. and Ewing, R. C. (1998) Zirconia - A ceramic for excess weapons plutonium wastes, Mat. Res. Soc. Symp. Proc., in print.

29. Naguib, H. and Kelly, R. (1975), Criteria for bombardment-induced structural changes in non-metallic solids, Radiation Effects $25,1$.

30. Fleischer, E., Norton, M. Zaleski, M., Hertl, W. and C. Carter, (1991) Microstructure of hardened and softened zirconia after xenon implantation, $J$. Mater. Res. 6, 1905; Yu, N., Sickafus, K. E., Kodali, P. and Nastasi, M. (1997) In situ observation of defect growth beyond the irradiated region in yttria-stabilized 
zirconia induced by $400 \mathrm{keV}$ xenon ion-beam at -90 and $30^{\circ} \mathrm{C}, \mathrm{J}$. Nucl. Mater. 244, 266; Sickafus, K. E., Matzke, Hj., Yasuda, K., Chodak III, P., Verrall, R. A., Lucuta, P. G., Andrews, H. R., Turos, A., Fronknecht, R. and Baker, N. P. (1998) Radiation damage effects in cubic-stabilized zirconia irradiated with 72 MeV I' ions, Nucl. Instru. Meth. Phys. Res. B141, 358; Degueldre, C. and Paratte, J.-M. (1997) Basic properties of a zirconia-based fuel material for light water reactors, $\mathrm{Nucl}$. Technology 123, 21; Degueldre, C., Heimgartner, O., Ledergerber, G., Sasajima, N., Hojou, K., Muromura, T., Wang, L., Gong, W. and Ewing, R. C. (1997), Behavior of zirconia-based fuel material under Xe irradiation, Mat. Res. Soc. Symp. Proc. 439, 625.

31. Yu, N., Devanathan, R., Sickafus, K. E. and Nastasi, M. (1997) In situ observation of defect growth beyond the irradiated region in yttria-stabilized zirconia induced by $400 \mathrm{keV}$ xenon ion-beam at -90 and $30^{\circ} \mathrm{C}, J$. Mater. Res. 12 , 1766 (1997).

32. Robinson, K., Gibbs, G. V. and Ribbe P. H. (1971) The structure of zircon: A comparison with garnet, Am. Mineralogist 56, 782

33. Murakami, T., Chackoumakos, B. C. and Ewing, R. C. (1986) X-ray powder diffraction analysis of alpha event radiation damage in zircon $\left(\mathrm{ZrSiO}_{4}\right)$, Advances in Ceramics; Nuclear Waste Management II, Vol. 20, Clark, D. E., White, W. B. and Machiels, J., eds., Am. Ceram. Soc., 745-753.

34. Murakami, T., Chackoumakos, B. C. , Ewing, R. C., Lumpkin, G. R. and Weber, W. J. (1991) Alpha decay event damage in zircon, Am. Mineralogist 76, 1510-1532.

35. Farges, F. and Calas, G. (1991) Structural analysis of radiation damage in zircon and thorite: An X-ray absorption spectroscopy study, Am. Mineralogist 76, 60-73.

36. Farges, F. (1994) The structure of metamict zircon: A temperature-dependent EXAFS study, Physics and Chemistry of Minerals 20, 504-514.

37. Holland, H. D. and Gottfried, D. (1955) The effect of nuclear radiation on the structure of zircon, Acta Crystallographica 8, 291-300.

38. Weber, W. J., Ewing, R. C. and Wang, L. M. (1994) The radiation-induced crystalline-to-amorphous transition in zircon, J. Mater. Res. 9(3),688-698.

39. Anderson, E. B., Burakov, B. E. and Vailiev, V. G. (1993) Creation of a crystalline matrix for actinide waste at the Khlopin Radium Institute, Proc. of SAFEWASTE '93, 2, 29-33.

40. Anderson, E. B., Burakov, B. E.. and Pazukhin, E. M. (1994) High-uranium zircon from Chernobyl Lava, Radiochimica Acta 60, 149-151.

41. Keller, C. (1963) Untersuchungen ueber die Germanate und Silicate des Typs $\mathrm{ABO}_{4}$ der Vierwertigen Elemente Thorium bis Americium, Nukleonik 5, 41 .

42. Huang, J. Y. and Spearing D. R. (1997) Hot isostatic pressing (HIP) synthesis of Pu-bearing zircon, Plutonium Futures - The Science, Conference Transactions, Los Alamos National Laboratory, 109-110. 
43. Mumpton, F. A. and Roy, R. (1961) Hydrothermal stability studies of the zirconthorite group, Geochim. Cosmochim. Acta 21, 217-238.

44. Ushakov, S. V., Gong, W. L., Yagovkina, M. M., Helean, K. B., Lutze, W. and Ewing, R. C., Solid solutions of Ce, Y, and Th in zircon, Ceram. Trans. 1998, in print.

45. Pidgeon, R. T., O’Neil J. R., and Silver, L. T. (1967) Uranium and lead isotopic stability in a metamict zircon under experimental hydrothermal conditions, Science, $154,1538-1540$.

46. Prasad, E. A. V., and Naidu M. G. C. (1971) Leaching patterns in monazite and zircon Current Science, 1, 14-15.

47. Ewing, R. C., Haaker, R. F., and Lutze, W. (1982) Leachability of zircon as a function of alpha dose. Scientific Basis for Nuclear Waste Management-V.

Elsevier Science Publishing, p. 389-397.

48. Ewing, R. C., Haaker, R. F., and Lutze, W. (1982) Leachability of zircon as a function of alpha dose. Scientific Basis for Nuclear Waste Management-V. Elsevier Science Publishing, p. 389-397.

49. Harrison, T. M., and Watson, E. B. (1983) Kinetics of zircon dissolution and zirconium diffusion in granitic melts of variable water content. Contrib. Miner. Petrol., 84, 66-72.

50. Tole, M. P. (1985) The kinetics of dissolution of zircon. Geochim. Cosmochim. Acta, 49, 453-458.

51. Ayers, J. C. and Watson, E. B. (1991) Solubility of apatite, monazite, zircon, and rutile in supercritical aqueous fluids with implications for subduction zone geochemistry. Philos. Trans. Royal Soc. London, A 335, 365-375.

52. Curtis, C.E., and Sowman, H.G. (1953) Investigation of the thermal dissociation, reassociation, and synthesis of zircon. J. Amer. Cerm. Soc., 36(6), 190-198.

53. Ballman, A.A., and Laudise, R.A. (1964) Crystallization and solubility of zircon and phenacite in certain molten salts. J. Am. Ceram. Soc., 48(3), 130-133.

54. Rosen, E., and Muan, A. (1965) Stability of zircon in the temperature range $1180^{\circ}$ to $1366^{\circ}$ C. J. Am. Ceram. Soc., 48 (11), 603-604.

55. Schuiling, R. D., Vergouwen, L., and van der Rijst, H. (1976) Gibbs energies of formation of zircon $\left(\mathrm{ZrSiO}_{4}\right)$, thorite $\left(\mathrm{ThSiO}_{4}\right)$, and phenacite $\left(\mathrm{Be}_{2} \mathrm{SiO}_{4}\right) . \mathrm{Am}$. Miner. 61, 166-168.

56. Kanno Y. (1989) Thermodynamic and crystallographic discussion of the formation and dissociation of zircon. J. Mater. Sci., 24, 2415-2420.

57. Ellison, A. J. G., and Navrotsky, A. (1992) Enthalpy of formation of zircon. $J$. Am. Ceram. Soc., 75(6), 1430-1433. 
58. Richet, P., Bottinga, Y., Denielou, L., Jpetitet, P. and Tequi, C. (1982)

Thermodynamic Properties of Quartz, Cristolbalite and Amorphous $\mathrm{SiO}_{2}$ : Drop Calorimetry Measurements between 1000 and $1800 \mathrm{~K}$ and a Review from 0 to 2000 K. Geochim. Cosmochim. Acta, 46(12) 2639-2658.

59. Chase, M. W., Davies, C. A., Downey, J. R., Frurip, D. J., McDonald, R. A., and Syverud, A. N. (1985) Janaf Thermochemical Tables, $3^{\text {rd }}$ Edition. J. Phys. Chem. Ref. data, 14, Suppl. 1, 1-1856.

60. Naumov, G. B., Ryzhenko, B. N., and Khodakovsky, I. L. (1974) Handbook of Thermodynamic Data, National Bureau of Standards Technical Notes 270-4 through 270-7.

61. Bruno, J., personal communication, 1998.

62. Bilinski, H., Branica, M., and Sillen, L. G. (1966) Precipitation and hydrolysis of metallic ions II, studies on the solubility of zirconium hydroxide in dilute solutions and in $1 \mathrm{M} \mathrm{NaClO}_{4}$. Acta Chem. Scan., 20, 853-861.

63. Grenthe, I., Fuger, J., Konings, R .J. M., Lemire, R. J., Muller, A. B., NguyenTrung, C., and Wanner, H. (1992) Chemical Thermodynamics of Uranium. OECD NEA, North Holland Publishing.

64. Slobodov, A. A., Kritskii, A. V., Zarembo, V. I., and Puchkov, L. V. (1992) Thermodynamic analysis of the chemical reactions of zirconium with aqueous solutions. Translated from Zhurnal Prikladnoi Khimii, 65, 1031-1041.

65. Robie, R. A. and Hemingway, B. S. (1995) Thermodynamic Properties of Minerals and Related Substances at $298.15 \mathrm{~K}$ and $1 \mathrm{Bar}\left(10^{5}\right.$ Pascals) and at Higher Temperatures, United states government Printing Office, Washington DC; Wagman D. D., Evans, W. H., Parker, V. B., Schumm, R. H., Halow, I., Bailey, S. M., Churney, K. L., and Nuttall, R. L. (1982) The National Bureau of Standards tables of chemical thermodynamic properties: Selected values for inorganic and $\mathrm{C}_{1}$ and $\mathrm{C}_{2}$ organic substances in SI units, J. Phys. Chem. Ref. Data 11, suppl. No. 2, 392 p.

66. Oka, J. (1938) The solubility of zirconium hydroxide. J. Chem. Soc. Jpn, 59, 971; Koreman, I.M. (1955) Solubility studies of zirconium aqueous species. Russ. J. Phys. Chem., 25, 1859; Starik, I. E., Ratner, A. P., Skul'skii, I. A., and Gavrilov, K. A. (1957) Thermodynamic analysis of zirconium hydroxide. Russ. J. Phys. Chem., 2, 1175; Kovalenski, P. N., and Bagdasarov, K. N. (1961) The solubility of zirconium hydroxide. Russ. J. Inorg. Chem., 6, 272275.

67. Aja, S. U., Wood, S. A., and Williams-Jones, A. E. (1995) The aqueous geochemistry of $\mathrm{Zr}$ and the solubility of some $\mathrm{Zr}$-bearing minerals. Appl. Geochem., 10, 603-620.

68. Paul, A. (1982) Chemistry of Glasses, 293 p. Chapman and Hall, London.

69. Ringwood, A. E., Kesson, S. E., Reeve, K.D., Levins, D. M., and Ramm, E. J. (1988) Synroc. Radioactive waste Forms for the Future, eds. W. Lutze, R.C. Ewing, North-Holland, 233-334. 
70. Weber, W. J. (1991) Self-radiation damage and recovery in Pu-doped zircon. Rad. Eff. Def. Solids, 115, 341-349.

71. Helean, K. B., Burakov, B. E. Anderson, E. B., Strykanova, E. E., Ushakov, S. V, and Ewing, R. C. (1996) Mineralogical and microtextural characterization of "gel-zircon". Mat. Res. Soc. Symp. Proc. 465, 1219-1225.

72. Komarneni, S., Roy, R. (1988) Synthesis of zircon, in Zircon, Science and Technology, edited by S. Somiya, Uchidarikakuko, Japan, pp. 289-298.

73. Kobayashi, H, Terasaki, T. Mori, H. Yamamura, and Mitanura, T. (1991) Preparation of $\mathrm{ZrSiO}_{4}$ powder using sol-gel process 4. Preparation from $\mathrm{ZrOCl}_{2}$ and colloidal $\mathrm{SiO}_{2}$, J. Ceram. Soc. Jpn. 99, 227-232.

74. Kobayashi, H., Terasaki, T. Mori, H. Yamamura, and Mitamura, T. (1991) Preparation of $\mathrm{ZrSiO}_{4}$ powders by sol-gel process .3. Preparation conditions of $\mathrm{ZrSiO}_{4}$ composition precursor gels from $\mathrm{Si}\left(\mathrm{OC}_{2} \mathrm{H}_{5}\right)_{4}$ and $\mathrm{Zr}\left(\mathrm{OC}_{3} \mathrm{H}_{7}\right)_{4}$ alkoxides, $J$. Ceram. Soc. Jpn. 99, 42-46.

75. Mori, T., Yamamura, H., Kobayashi, H., and Mitamura, T. (1991) Sintering of high-purity $\mathrm{ZrSiO}_{4}$ powder, J. Ceram. Soc. Jpn. 99, 1098-1102.

76. Mori, T., Yamamura, H., Kobayashi, H., and Mitamura, T. (1992) Preparation of high-purity $\mathrm{ZrSiO}_{4}$ powder using sol-gel processing and mechanical properties of the sintered body, J. Amer. Ceram. Soc. 75, 2420-2426.

77. Tartaj, P., Sanz, J., Serna, C.J., and Ocaña, M. (1994) Zircon formation from amorphous spherical $\mathrm{ZrSiO}_{4}$ obtained by hydrolysis of aeosols, J. Mater. Sci. 29, 6533-6538.

78. Mori, T. Yamamura, H., Kobayashi, H, and Mitamura, T. (1993) formation mechanism of $\mathrm{ZrSiO}_{4}$ powders, J. Mater. Sci. 28, 4970-4973.

79. Ono, T. Kagawa, M. and Syono, Y. (1985) ultrafine particles of the $\mathrm{ZrO}_{2}-\mathrm{SiO}_{2}$ system prepared by the Spray-ICP technique, J. Mater. Sci. 20, 2483-2487.

80. Kanno, Y. and Suzuki T. (1988) Estimation of formation mechanism of spherical fine $\mathrm{ZrO}_{2}-\mathrm{SiO}_{2}$ particles by ultrasonic spray pyrolysis, J. Mater. Sci. 23, 30673072.

81. Jada, S.S. (1990) Preparation of hollow zircon $\left(\mathrm{ZrSiO}_{4}\right)$, J. Mater. Sci. Lett. 9, 565-568.

82. Mumpton, F. A. and Roy, R. (1960) Low-temperature equilibria among $\mathrm{ZrO}_{2}$, $\mathrm{ThO}_{2}$ and $\mathrm{UO}_{2}$, J. Am. Ceram. Soc. 43, 234.

83. Keller, C. (1963) Untersuchungen uber dier germanate and silikate des typs $\mathrm{ABO}_{4}$ der vierwertigen elemente thorium bis americium, Nucleonik, 5, 41-48.

84. Haaker, R. F. and Ewing, R. C. (1982) Solution-gelation method for preparing polycrystalline zircon, J. Am. Ceram. Soc., 64, C-149. 
85. Yoshimura, M, Kim, K. J., Tani, E., and Somiya, S (1988) ESTABLISHMENT of the equilibrium phase-diagrams in fluorite-related systems, $\mathrm{ZrO}_{2}-\mathrm{CeO}_{2}$ and $\mathrm{SrF}_{2}-\mathrm{LaF}_{3}$, hydrothermal techniques, Solid State Ionics , 28, 452-457. 